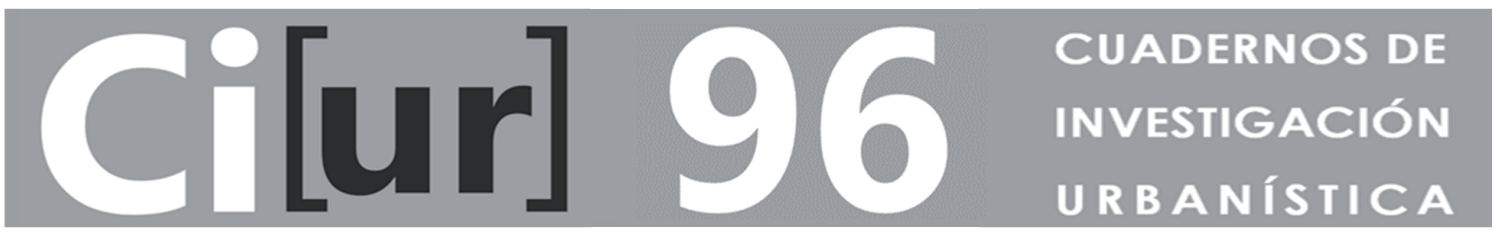

\title{
THE URBAN MICROCLIMATE IN OPEN SPACE. CASE STUDIES IN MADRID.
}

\author{
IRINA TUMINI \\ Doctor Ingeniero-Arquitecto
}

Este documento es un resumen de la tesis doctoral "El microclima urbano en los espacios abiertos: estudio de casos en Madrid", dirigida por la profesora Ester Higueras García y leída por su autora el día 25 de febrero de 2013, en la Escuela Técnica Superior de Arquitectura de Madrid.

Septiembre / Octubre 2014 


\begin{tabular}{|c|c|}
\hline Director: & José Fariña Tojo \\
\hline \multicolumn{2}{|c|}{ Consejo de Redacción: } \\
\hline Director & Ester Higueras García \\
\hline Jefe de redacción & María Emilia Román López \\
\hline Vocales & $\begin{array}{l}\text { Julio Alguacil Gómez (Univ. Carlos III de Madrid), Pilar Chías Navarro (Univ. Alcalá } \\
\text { de Henares, Madrid), José Antonio Corraliza Rodríguez (Univ. Autónoma de } \\
\text { Madrid), Alberto Cuchí Burgos (Univ. Politécnica de Cataluña), José Fariña Tojo } \\
\text { (Univ. Politécnica de Madrid), Agustín Hernández Aja (Univ. Politécnica de Madrid), } \\
\text { Mariam Leboreiro Amaro (Univ. Politécnica de Madrid), Rafael Mata Olmo (Univ. } \\
\text { Autónoma de Madrid), Fernando Roch Peña (Univ. Politécnica de Madrid), Carlos } \\
\text { Manuel Valdés (Univ. Carlos III de Madrid) }\end{array}$ \\
\hline Consejo Asesor: & $\begin{array}{l}\text { Ma Teresa Arredondo (Directora de Relaciones con Latinoamérica, Univ. } \\
\text { Politécnica de Madrid), Luis Maldonado (Director de la Escuela Superior de } \\
\text { Arquitectura, Univ. Politécnica de Madrid), Antonio Elizalde, Julio García Lanza, } \\
\text { Josefina Gómez de Mendoza, José Manuel Naredo, Julián Salas, Fernando de Terán }\end{array}$ \\
\hline Comité Científico: & $\begin{array}{l}\text { Antonio Acierno (Univ. Federico II di Napoli, Nápoles, ITALIA), Miguel Ángel } \\
\text { Barreto (Univ. Nal. del Nordeste, Resistencia, ARGENTINA), Luz Alicia Cárdenas } \\
\text { Jirón (Univ. de Chile, Santiago de Chile, CHILE), José Luis Carrillo (Univ. } \\
\text { Veracruzana, Xalapa, MÉXICO), Marta Casares (Univ. Nal. de Tucumán, } \\
\text { ARGENTINA), María Castrillo (Univ. de Valladolid, ESPAÑA), Mercedes Ferrer } \\
\text { (Univ. del Zulia, Maracaibo, VENEZUELA), Fernando Gaja (Univ. Politécnica de } \\
\text { Valencia, ESPAÑA), Alberto Gurovich (Univ. de Chile, Santiago de Chile, CHILE), } \\
\text { Josué Llanque (Univ. Nal. S. Agustín Arequipa, PERÚ), Angelo Mazza (Univ. } \\
\text { Federico II di Napoli, Nápoles, ITALIA), Luis Moya (Univ. Politécnica de Madrid, } \\
\text { ESPAÑA), Joan Olmos (U. Politécnica de Valencia, ESPAÑA), Ignazia Pinzello (Univ. } \\
\text { degli Studi di Palermo, Palermo, ITALIA), Julio Pozueta (Univ. Politécnica de } \\
\text { Madrid, ESPAÑA), Alfonso Rivas (UAM Azcapotzalco, Ciudad de México, MÉXICO), } \\
\text { Silvia Rossi (Univ. Nal. de Tucumán, ARGENTINA), Adalberto da Silva (Univ. } \\
\text { Estadual Paulista, Sao Paulo, BRASIL), Carlos Soberanis (Univ. Francisco } \\
\text { Marroquín, Guatemala, GUATEMALA), Carlos A. Torres (Univ. Nal. de Colombia, } \\
\text { Bogotá, COLOMBIA), Graziella Trovato (Univ. Politécnica de Madrid, ESPAÑA) } \\
\text { Carlos F. Valverde (Univ. Iberoamericana de Puebla, MÉXICO), Paz Walker (Univ. } \\
\text { de la Serena, Santiago de Chile, CHILE), Fernando N. Winfield (Univ. Veracruzana, } \\
\text { Xalapa, MÉXICO) }\end{array}$ \\
\hline
\end{tabular}

Maquetación: Antonio Jesús Antequera Delgado: ciur.urbanismo.arquitectura@upm.es

Distribución: Mairea Libros: distribucion@mairea-libros.com

\section{(C) COPYRIGHT 2014}

IRINA TUMINI

I.S.S.N. (edición impresa): 1886-6654

I.S.S.N. (edición digital): 2174-5099

Año VII, Núm. 96, septiembre-octubre 2014, 78 págs.

Edita: Instituto Juan de Herrera

Imprime: FASTER, San Francisco de Sales 1, Madrid 


\section{DESCRIPTORES:}

Microclima urbano / Sensación térmica / Isla de calor urbana / Cañón urbano

\section{KEY WORDS:}

Urban microclimate / Thermal sensation / Urban heat island / Urban canyon

\section{RESUMEN:}

El microclima urbano juega un rol importante en el consumo energético de los edificios y en las sensaciones de confort en los espacios exteriores. La urgente necesidad de aumentar la eficiencia energética, reducir las emisiones de los contaminantes y paliar la evidente falta de sostenibilidad que afecta a las ciudades, ha puesto la atención en el urbanismo bioclimático como referente para una propuesta de cambio en la forma de diseñar y vivir la ciudad. Hasta ahora las investigaciones en temas de microclima y eficiencia energética se han concentrado principalmente en como orientar el diseño de nuevos desarrollo. Sin embargo los principales problemas de la insostenibilidad de las actuales conurbaciones son el resultado del modelo de crecimiento especulativo y altamente agotador de recursos que han caracterizado el boom inmobiliario de las últimas décadas. Vemos entonces, tanto en España como en el resto de los Países Europeos, la necesidad de reorientar el sector de la construcción hacía la rehabilitación del espacio construido, como una alternativa capaz de dar una solución más sostenible para el mercado inmobiliario. La sensación térmica condiciona la percepción de un ambiente, así que el microclima puede ser determinante para el éxito o el fracaso de un espacio urbano. Se plantea entonces cómo principal objetivo de la investigación, la definición de estrategias para el diseño bioclimático de los entornos urbanos construidos, fundamentados en las componentes morfotipológica, climática y de los requerimientos de confort para los ciudadanos. Como ulterior elemento de novedad se decide estudiar la rehabilitación de los barrios de construcción de mediado del siglo $\mathrm{XX}$, que en muchos casos constituyen bolsas de degrado en la extendida periferia de las ciudades modernas. La metodología empleada para la investigación se basa en la evaluación de las condiciones climáticas y de confort térmico de diferentes escenarios de proyecto, aplicados a tres casos de estudio situados en un barrio periurbano de la ciudad de Madrid. Para la determinación de los parámetros climáticos se han empleado valores obtenidos con un proceso de simulación computarizada, basados en los principios de fluidodinámica, termodinámica y del intercambio radioactivo en el espacio construido. A través de uso de programas de simulación podemos hacer una previsión de las condiciones microclimáticas de las situaciones actuales y de los efectos de la aplicación de medidas. La gran ventaja en el uso de sistemas de cálculo es que se pueden evaluar diferentes escenarios de proyecto y elegir entre ellos el que asegura mejores prestaciones ambientales. Los resultados obtenidos en los diferentes escenarios han sido comparados con los valores de confort del estado actual, utilizando como indicador de la sensación térmica el índice UTCI. El análisis comparativo ha permitido la realización de una tabla de resumen donde se muestra la evaluación de las diferentes soluciones de rehabilitación. Se ha podido así demostrar que no existe una solución constructiva eficaz para todas las aplicaciones, sino que cada situación debe ser estudiada individualmente, aplicando caso por caso las medidas más oportunas. 
Si bien los sistemas de simulación computarizada pueden suponer un importante apoyo para la fase de diseño, es responsabilidad del proyectista emplear las herramientas más adecuadas en cada fase y elegir las soluciones más oportunas para cumplir con los objetivos del proyecto.

\section{ABSTRACT:}

The urban microclimate plays an important role on buildings energy consumption and comfort sensation in exterior spaces. Nowadays, cities need to increase energy efficiency, reduce the pollutants emissions and mitigate the evident lack of sustainability. In reason of this, attention has focused on the bioclimatic urbanism as a reference of change proposal of the way to design and live the city. Hitherto, the researches on microclimate and energy efficiency have mainly concentrated on guiding the design of new constructions. However the main problems of unsustainability of existing conurbations are the result of the growth model highly speculative and responsible of resources depletion that have characterized the real estate boom of recent decades. In Spain and other European countries, become define the need to redirect the construction sector towards urban refurbishment. This alternative is a more sustainable development model and is able to provide a solution for the real estate sector. The thermal sensation affects the environment perception, so microclimate conditions can be decisive for the success or failure of urban space. For this reasons, the main objective of this work is focused on the definition of bioclimatic strategies for existing urban spaces, based on the morpho-typological components, climate and comfort requirements for citizens. As novelty element, the regeneration of neighborhoods built in middle of the twentieth century has been studied, because are the major extended in periphery of modern cities and, in many cases, they represent deprived areas. The research methodology is based on the evaluation of climatic conditions and thermal comfort of different project scenarios, applied to three case studies located in a suburban neighborhood of Madrid. The climatic parameters have been obtained by computer simulation process, based on fluid dynamics, thermodynamics and radioactive exchange in urban environment using numerical approach. The great advantage in the use of computing systems is the capacity for evaluate different project scenarios. The results in the different scenarios were compared with the comfort value obtained in the current state, using the UTCI index as indicator of thermal sensation. Finally, an abacus of the thermal comfort improvement obtained by different countermeasures has been performed. One of the major achievement of doctoral work is the demonstration of there are not any design solution suitable for different cases. Each situation should be analyzed and specific design measures should be proposed. Computer simulation systems can be a significant support and help the designer in the decision making phase. However, the election of the most suitable tools and the appropriate solutions for each case is designer responsibility.

\section{CONSULTA DE NÚMEROS ANTERIORES/ACCESS TO PREVIOUS WORKS:}

La presente publicación se puede consultar en color en formato pdf en la dirección:

This document is available in pdfformat and full colour in the following web page:

http://www2.aq.upm.es/Departamentos/Urbanismo/institucional/publicaciones/ciur/ 


\section{ÍNDICE}

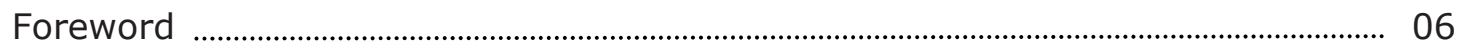

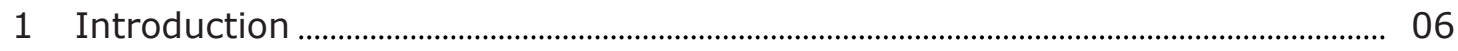

1.1 Thesis hypothesis, objective and research methodology ................................ 07

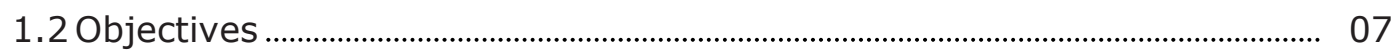

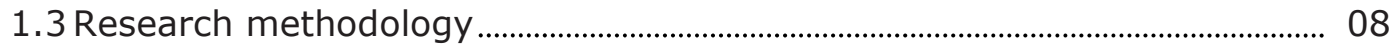

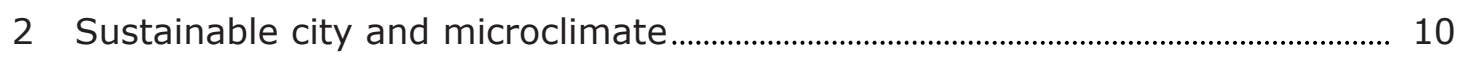

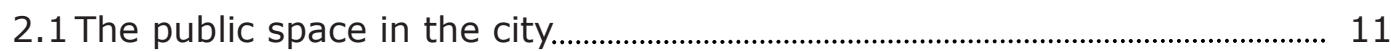

2.2 Urban regeneration: a commitment towards the sustainability................... 12

2.3 The climate in the urban environment ................................................................ 13

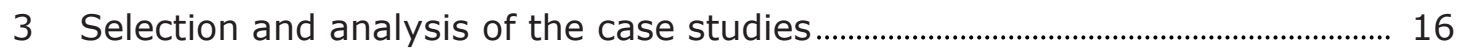

3.1 Use of numerical method ........................................................................................ 21

3.2 Description of simulation model ........................................................................... 23

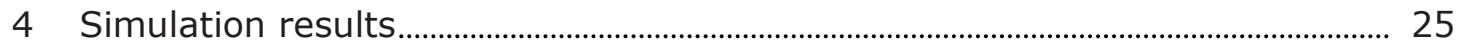

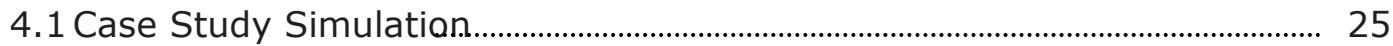

4.2 Validation of the simulation model ................................................................... 26

4.3 Discussion of Case Studies Analysis ...................................................................... 28

4.4 Results of scenarios simulation .......................................................................... 34

4.5 Discussion of Scenarios Simulation Result ............................................................. 36

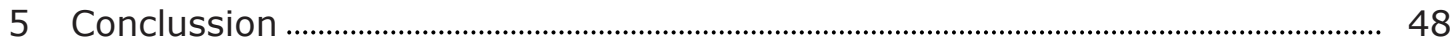

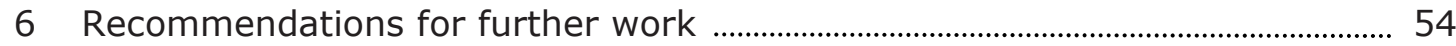

7 Bibliography

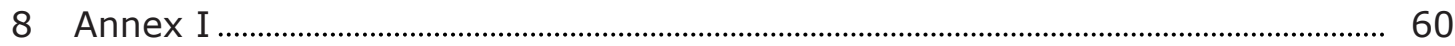




\section{FOREWORD}

This document is the reworked doctoral thesis research on previous "El microclima urbano en los espacios abiertos. Estudio de casos en Madrid." which aims to study microclimate of outdoor urban space and the capability to predict its behaviour through the use of computer simulation systems.

The first part of the thesis document gathers the state of the art analysis regarding the research: on the urban microclimate, on the main thermal comfort evaluation systems in open spaces and a critical review of energy simulation tools available to evaluate outdoor spaces is presented. The second part presents various case studies, defining the selection criteria and the simulation work carried out. The research focuses on the assessment of the impact produced by the measures applied to an urban existing space. This evaluation is performed through a comparison of the parametric approaches of different project scenarios within the current case.

In this paper, the state of the art has been omitted. Instead, it includes a description of the context in which the study is inserted: the unsustainability of the city, the role of public space and urban renovation as model of change.

\section{INTRODUCTION}

Cities create a strong impact producing important changes on the surrounding environment: reduction of natural spaces replaced by houses and roads, impervious surfaces use, air and water pollution and biodiversity changes are just some consequences of conurbation. Amongst the many negative effects, it should be outlined the change of climatic conditions of which the most prominent features are: temperature increases, changes in the intensity of winds and humidity and rainfall distribution alteration. (Oke 1980, Olgyay 1969, Santamouris et al. 2001, López Gómez et al. 1991)

The urbanization and the anthropogenic activities developed inside urban areas create a so-called urban microclimate that can be described as the difference of conditions observed between the cities and the surrounding rural areas. As a consequence of this climate change, the need of heating and cooling of the building, are not the same in both environments. On the other hand, the problem could be studied from the point of view of thermal comfort in the outdoor spaces (Mirzaei, Haghighat 2010, Santamouris et al. 2001).

The rapidly increasing concentration of people in urban areas along with the focus on the quality of life improvement and revitalizing city centres, has led to the interest in the quality of open urban spaces. It is well known that weather is an important factor for the use and perception of outdoor urban space; designing cities with climate in mind may result in health, social, economic, and environmental benefits. Thus, by integrating social and environmental objectives, it will be possible to improve the quality of life and revitalize cities, strengthening social interaction between citizens, by improving the experience of people in open space (Dimoudi, Nikolopoulou 2003, Nikolopoulou 2004, Nikolopoulou, Lykoudis 2007, Givoni 1998, Knez et al. 2009). 
The continuous urbanization spread, combined with the degradation of the urban climate and the recent upsurge of environmental problems, as well as the concern for the reduction of energy consumption, define the reconsideration of the architectural and urban planning as the major priorities. As defined by Stanners and Bourdeau (1995): Sustainable cities are cities that provide a liveable and healthy environment for their inhabitants and meet their needs without impairing the capacity of the local, regional and global environmental systems to satisfy the needs of future generations (Santamouris et al. 2001, D. Stanners 1995).

The global economic crisis, which affects especially the real estate sector, has called into question the growth model, based on the natural soil occupation. An alternative model should be focused on what we mean by 'inner city'1 (Bruquetas Callejo et al. 2005, Fariña Tojo, Naredo 2010, Naredo 2003), especially in deprived neighbourhoods; apart from improving a range of aspects as the living conditions of citizens and the environmental quality limiting natural soil occupation. On the other hand, different agents propose the urban renovation as an alternative to reorient the construction sector toward a more sustainable model. Examples of these may be seen in Spain or other European Countries (Fariña Tojo, Naredo 2010, Cuchí, Sweatman 2011, Valenzuela Rubio 2009).

For all these reasons, research on the urban climate problem is focused on the aspects related to thermal comfort and citizen well-being oriented towards the amelioration of public outdoor spaces in the 'inner city'.

\subsection{Thesis hypothesis, objective and research methodology}

As mentioned before, urban space creates unique climatic conditions called the urban microclimate. The first research hypothesis states that it is possible to associate the urban morphology to microclimatic behaviour, or in other words, to define microclimatic patterns characteristic for each urban typology.

The second hypothesis is based on the observation that the environmental conditions influence the use of the urban outdoor space. If it is possible to quantify the thermal comfort through the study of climatic parameters, the modification of the urban microclimate will affect the thermal comfort of people.

The confirmation of both assumptions leads to the definition of a third hypothesis: it is possible to mitigate the impact of the microclimate through the modification of the existing urban space, and consequently, improve citizens thermal comfort conditions.

\subsection{Objectives}

The attempt of this doctoral study is to elaborate strategies for the environmental design of urban spaces in the warm-temperate climate. It may apply for the

\footnotetext{
1 Inner City. Traditional, multifunctional and comprehensive urban areas. Normally this concept is associated with the historic city center, but can be considered as well as many of the suburban neighborhoods that have developed a number of diversified functions and uses, minimal services and with a complex social tissue.
} 
renovation of existing neighbourhoods, based on the study of climate and morphotypological components of the space, the thermal comfort and energy saving requirements within a sustainable approach.

The specific objectives to achieve this goal are:

1. Provide with a system of indicators to characterize and describe the physical and environmental aspects of studied areas. These indicators should be able to describe the current situation and guide a renovation project.

2. Define indicators for the analysis of microclimatic aspects of outdoor spaces which establish a relationship with environmental conditions and comfort sensation, in order to find a minimum quality target.

3. Establish a calculation methodology in order to evaluate the microclimatic quality and the level of comfort in public spaces in an objective way and suitable for the application in other cases and other locations.

4. Elaborate the guidelines for the urban refurbishment of the 20th century city, from the perspective of microclimatic and environmental improvement of urban areas for warm-temperate climates.

5. Evaluate specific software for the simulation of climatic phenomena which occur in outdoor urban space, highlighting its advantages and limitations.

\subsection{Research methodology}

The research begins with the state of the art review regarding the study of the thermal behaviour in urban spaces, with particular reference to the urban heat island effect, the influence on energy consumption, thermal comfort and therefore on the use of outdoor space. The review shows that the problem of urban heat island effects is an understudy since many years ago. However, there are still many gaps in the knowledge concerning the ability to forecast and calculate the energy performance of urban spaces. The thermal behaviour improvement of existent urban area is a theme almost unexplored because researches, measures and guidelines focus mainly on the design of new developments.

One of the main objectives of this research work was to improve the outdoor space perception through urban microclimate amelioration. For this reason, the definition of a thermal comfort index suitable for outdoor spaces was of fundamental importance. Also, it should be applicable to Madrid's climate conditions and calculable using climatic parameters. The selection of the index has influenced the choice of the calculation system too, because it should be able to provide the output required for the index calculation. A review of the state of the art on outdoor thermal comforts indexes was done, and after conducting an empirical study of different systems; the Universal Thermal Climate Index (UTCI) (Jendritzky et al. 2012, Bröde et al. 2012b, Bröde et al. 2012a, Fiala et al. 2012, Havenith et al. 2012) was chosen for this study. 
The parameters required for the index calculation are: air temperature, mean radiant temperature, wind speed and relative or absolute humidity.

For the thermal behaviour analysis, the experimental methodological approach is probably one of the most used. However, works based on field measurements are expensive, require a lot of equipment, specialized technicians and large time expenditure. Furthermore, the theoretical formulation is very difficult due to the many factors involved in the microclimate and, in many cases, the results are not applicable elsewhere. (Mirzaei, Haghighat 2010, Ali-Toudert, Mayer 2006). This research added the difficulty of trying a new subject: the energetic renovation of 20th century city.

Another applied research method is the numerical approach. Nowadays, many works are moving towards this approach for two main reasons:

a) The numerical model is particularly suitable for highlighting the connection between the physical urban structure, the microclimate and thermal comfort, by making easier the translation from the results to practical design guideline;

b) Compared with extensive field measurements, it is faster and less expensive. It also allows the comparison between numerous case studies and project scenarios. (Ali-Toudert, Mayer 2006, Robinson 2011, Samaali et al. 2007)

Urban microclimate models vary substantially according to their physical basis and their temporal and spatial scale. On the microscale, three-dimensional (3D) wind flow models are the most used. Therefore, such models includes hydrothermal and energy processes. Urban canyon models are typical examples; they use simplified turbulence schemes, which are combined with 3D flow modelling and 2D energy modelling. Furthermore, very few microclimate models evaluate thermal comfort. This is mainly due to the difficulty of determining the human body repercussion in urban areas produced by complex radiation fluxes. This problem is often caused by the use of simplified methods, in which many atmospheric processes are removed and replaced by data set (Ali-Toudert, Mayer 2006).

The numerical approach has been used in this research. The work is based on real case studies and the analysis of different scenarios for testing the effects on microclimate and comfort sensation as result of the modification of urban design elements (Tumini 2013). The work phases are listed briefly below:

I. Case studies selection and analysis;

II. Simulation performance model;

III. Selection of morpho-typological indicators, microclimatic parameters and thermal comfort analysis for each case study;

IV. Renovation scenarios simulation and comparative study;

V. Definition of the design guide and summary abacus. 


\section{SUSTAINABLE CITY AND MICROCLIMATE}

Cities have never foster as many people as today. According to the UN-HABITAT report (2008) more than half of the world population lives in cities and by 2030 this value will increase up to $60 \%$. Cities represent the highest contribution to global gross national product, as well as the major resources depletion and waste generators. It is clear that the future of civilization is linked to city development. (Fariña Tojo 2003a, Rogers, Gumuchdjian 2000, Smith, Levermore 2008)

The city of the future must face some environmental problems such as growing fossil fuels dependence, natural resources depletion and waste and pollution generation. (Rogers, Gumuchdjian 2000) According to this, 'The Sustainable City' introduces a conceptual approach that goes beyond the search of solutions with low environmental impact; it calls into question the traditional urban and territorial development model and the way to think and design the city. (Turégano Romero 2009)

To better understand the environmental aspects linked to the adjective "sustainable", the natural ecosystems can be observed: they are able to satisfy the three functions of production, consumption and decomposition inside the system. Today it is know that the biosphere has been able to develop itself by closing cycles. What is a waste for some, it is a resource for many others in a continuous recycle where all the wasted is being reused. In this context, we can place the relationship between the city and the sustainability, or rather, its "unsustainability". As a result of this strong dependence on the outside, urban agglomerations exert a strong load on their surroundings, and are responsible for the alteration of the natural processes and the natural ecosystems impoverishment. (Naredo 2003, IDAE-Instituto Para la Diversificación y Ahorro de la Energía 2000, Naredo 2005)

The sustainability in the Spanish cities replicates the overall situation described. The real estate boom, that in Spain began in the late $90 \mathrm{~s}$, has been characterized by a speculative model of growth, causing resource depletion and today's main guilty for the economic crisis that grips the country.

Following the lack of liquidity, due to the subprime lending crisis (2008) on one hand and the deterioration of Spanish growth model on the other, there has been a strong drop in the housing demand and prices, destabilizing thereby the whole economic system based on the real estate market (de la Cruz Mera, Ángela 2010, Andreu 2009).

A change in the organization of urban systems and in the current territorial model is necessary and urgent. Re-direct the cities' development, based so far on the resource concentration coming from anywhere in the world and the emission towards these waste and other pollution impacts, is a difficult challenge. It can only be achieved if supported by effective policies and consistent investments, in lieu of isolated voluntarism events. The need to consider the different scales (the global, regional and local levels in particular) and to rethink the organization of economic, social, cultural, territorial, etc. should be taken in account. Although the urban footprint has a global dimension, the microscale is the level closest to the citizeninhabitant. It is the dimension in where the citizen can experience the sustainability 
achievements, but also where it can and should become active agent of the city (Valenzuela Rubio 2009).

For all of the above, in lieu of talking about sustainable city, it would be more appropriate to direct the effort pointing to a reduction of the developments unsustainability, paying attention not only to short-term local sustainability, but also to the effects on long-term and the whole impact expected. A successful proposal must consider many aspects, like the complexity of uses and functions, housing tenancy, resource management and citizen participation (Fariña Tojo 2003a, Naredo 2003).

The question is how we can improve the efficiency while reducing the environmental footprint of our cities without compromising the quality of life and comfort of citizens. Many issues related not only to the efficient use of energy and resources, but also with the same comfort and consumerism concept of the welfare society are implicit in this question (Fariña Tojo 2003b).

Without any doubt, the climatic conditions have a significant effect on the energy consumption, mainly because of buildings heating and air conditioning (Akbari et al. 2001, Niachou et al. 2001, Santamouris et al. 2001, Synnefa et al. 2007) as well as outdoor spaces air conditioning: e.g. outdoor heaters for winter or microclimate system for the summer.

Thermal perception influences our decisions in an outdoor space. Environmental conditions, climate among them, influence the use and the experience (visual stimulation, thermal, acoustic, etc..) we have in it (Steemers, Steane 2004). Urban spaces which are designed taking into account the thermal behaviour, result in better environmental quality and energy efficiency. They also encourage the use of public space, revitalize cities strengthen social interaction between citizens, and provide for such interaction to take place (Nikolopoulou, Lykoudis 2007).

\subsection{The public space in the city}

Public space is not a residual area between buildings, or empty space considered public just for legal definition, or a specialized space in which you have to attend to as a museum or a show. Public space is where society becomes visible, where the relations between citizens and city democracy are materialized (Borja, Muxi 2000).

According to Lefebvre (1972) urban space "is the place where contact between items and people happened, where exchange takes place" (Lefebvre 1973). Urban space shapes and is shaped by the combination of the relationships existing in a society. Closeness, exchange and contact between citizens are elements of the city. "Public space is an important space, comprehensive and fragile, in which happen dynamics of social inclusion dynamic or, conversely of tension and exclusion" (Florencia Rodríguez 2001).

The public space can be used as support for move through it; it can be a place of contemplation for walkers or for meeting and entertainment. It is often used collectively by families or groups and, in most cases, public space is the co-habitation and interaction between different groups (Torres Pérez 2002). Despite seeing that in modern cities, neoliberal urban policies have resulted in the urban space 
fragmentation and specialization. That is the main cause of sociability loss and vulnerable sectors exclusion. According to Lefebvre (1972) segregation breaks urbanity, destroys perceived and conceived relationships, avoids confrontation, ruins the plurality and destroys the social tissue (Torres Pérez 2002, Florencia Rodríguez 2001, Lefebvre 1973). The maintenance of certain cultural and social values, as well as integration between people, is achieved by protecting and preserving the space for contact, co-habitation and interaction between citizens.

The quality of a city is measured by the quality of its public space. A sustainable design cannot only comply with technological and design requirements, but it needs to involve the lifestyle and social aspects too. It should try to find more appropriate environmental solutions to alleviate the current urban problems. Therefore, the microscale is the ideal size to propose an environmental regeneration because it is the place where people live, act and suffer the damages of the city problems (Gómez de Perozo 2012).

\subsection{Urban regeneration: a commitment toward the sustainability}

The failure of developmental model and the unsustainability derived from it, suggest that the resurgence of the real estate sector cannot be pursued by new building:

- The real estate bubble has left a legacy of more than 700,000 new dwellings unoccupied.

- The stabilization of the demand for new housing due to the population growth stabilization to 2050 (National Statistics Institute-INE).

- The phenomenon of demand increase for second homes and the reduction of inhabitants per housing, it would not be enough magnitude to reverse the process.

Investments in the real estate sector, which until now have been considered as a solid investment for families, have been called into question both on its cultural aspects as well as financial mechanisms. The need to find new solutions to the financial crisis can provide with the opportunity to propose a change in the models of development, focusing on sustainability by:

- Lowering the environmental impact

- Reducing the resources used and the soil occupation

- Promoting social equity

Both institutional and private sectors are beginning to promote construction sector reconversion on the way to the renovation of existing buildings and urban spaces. There are clear advantages to renovation. It is always cheaper than a new development not only because it avoids consuming new soil, but also because it depletes less resources and produces a lower amount of waste. It is a beneficial solution as well according to economic policies, which can absorb part of the unemployment left by real estate sector crisis. (Cuchí, Sweatman 2011, Naredo 2005) 


\subsection{The climate in the urban environment}

In order to understand how the urban spaces behave, it is helpful to consider the thermodynamic concept of entropy as a measure of order dissipation. In our cities, entropy is caused by irreversible internal processes: from fuel combustion to heating buildings or transport. This internal production can be reduced by the efficient use of natural resources. For instance, coupling processes or internal re-use of waste. (Robinson 2011)

The increase of urbanization and industrialization has caused the urban environmental deterioration. A deficient control of urban developments have important consequences on urban climate and the environmental efficiency of buildings. As a consequence of change in the heat balance, climate in the densely urban environment shows a great difference from the surrounding rural areas. The phenomenon occurs as result of multiple factors, the most important of them are as summarized by Oke TR. (1991) and deal with:

- Canyon radiative geometry contributes to the decreasing the long wave radiation loss from street canyon as a result of the complex exchange between buildings and the screening of the skyline.

- Thermal properties of materials may increase the sensible heat storage in urban buildings and surfaces.

- The anthropogenic heat released from combustion of fuels and animals metabolism.

- Canyon radioactive geometry decreases the effective albedo of the system because the multiple reflection of short-wave radiation by the canyon surfaces.

- The reduction of the evaporated surfaces in the city transfers more energy into sensible heat and less into latent heat.

- The reduced turbulent exchange of heat from within street. (Santamouris et al. 2001).

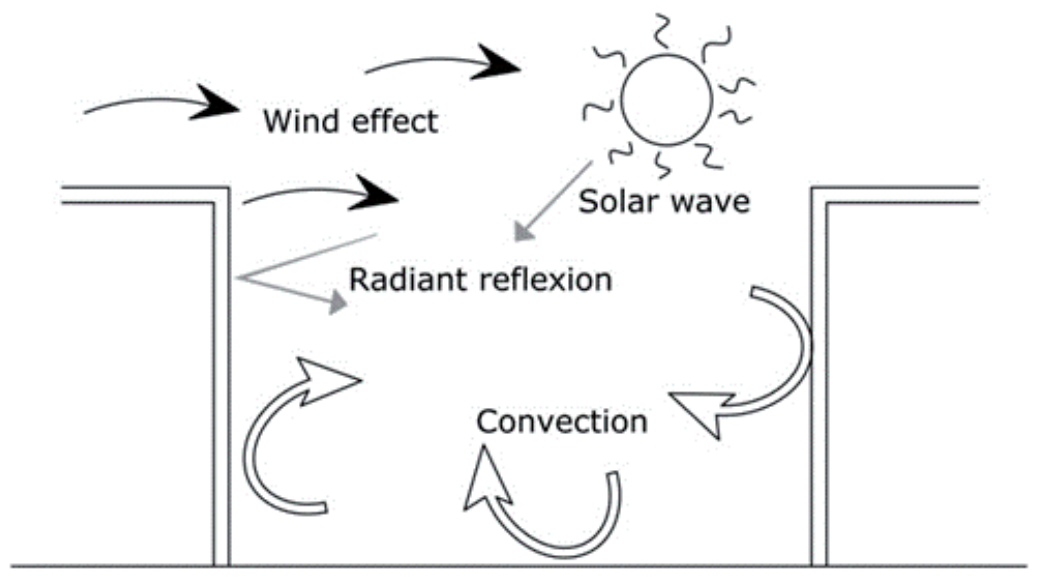

Figure 1. Description of heat and mass transfer in the urban canyon.

Source: Sánchez de la Flor, Francisco, Alvarez Dominguez 2004 
Besides considering differences with its surroundings rural areas, inside the city itself it is possible to recognize climatic differences between various zones (Cardenas Jiron 2010). Then, dealing with the urban climate, we can distinguish two study scales: mesoscale and microscale.

At the mesoscale, the element of study is the city and its size is over a few kilometers. The climate variations are produced by the conurbation. In this case, the factors that influence its intensity are topography and the proximity to water sources, such as rivers or large urban parks. By microscale we refer to the area limited to neighbourhood scale. The studied climatic variations are those which occur at small distances, a few meters due to the interaction of the atmosphere with urban elements (buildings, streets, squares, gardens, etc. see Figure 2.) (Wong 2007, Robinson 2011).

\section{MICROSCALE}

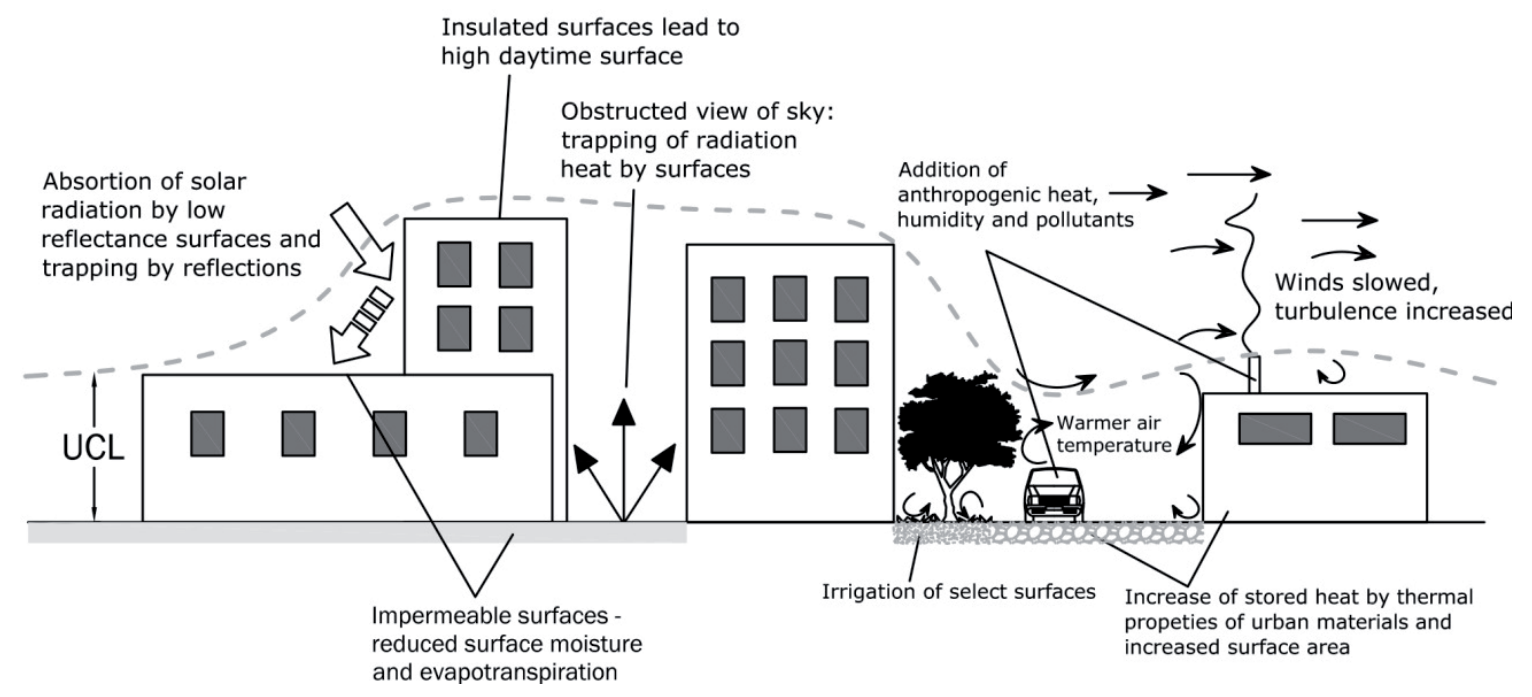

Figure 2. Urban Heat Island processes at microscale Source: (Voogt 2007) elaborated by Author.

The different climatic performance effects may produce more or less impact in relation to the site conditions. However, this phenomenon indicates environmental degradation and air pollution. The application of countermeasures produce environmental quality improvement through the whole year, which gives a positive balance. The main impacts produced by the urban climate are:

- The energy consumption increases due to building cooling systems, especially in warm climate conditions. This augmentation of air conditioning energy demand also results in an increase of GWP gases emissions ${ }^{2}$. But the extensive use of air

2 The Global Warming Potential (GWP) is a useful metric for comparing the potential climate impact of the emissions of different pollutant gases. Global Warming Potential compare the integrated radiative forcing over a specified period (e.g. 100 years) from unit mass pulse emission and are a way of comparing the potential climate change associated with emissions of different greenhouse gases (Intergouvernamental panel on climate change 2013). 
conditioning equipment has an economic concern as well. Raising energy electricity demand for cooling increments peak electricity utility loads which force the utilities to burn more fossil fuel, to augment energy cost and to use more powerful equipment in order to ensure comfort.

- Air pollution and the health loss: the growing of GWP and other gasses emissions, especially NOx produced by fossil combustions, and the temperature raisinig in urban areas, are the first cause of photochemical pollution.

- Use of outdoor spaces: the loss of outdoor thermal comfort could affect the perception of the users in public spaces, improving or ruining their experience. (Niachou et al. 2001, Santamouris et al. 2001, Nikolopoulou, Lykoudis 2006, Wong 2007, Polidori 2006, Oke 1988, Wong et al. 2010a)

The passive architecture is a good alternative to reduce resource consumption and improve the built spaces sustainability. But in order to achieve better results, it is necessary to introduce the passive design concepts at the urban level too. Literature about the urban climate is focused on understanding the influence of different urban elements in microclimate formation. With two main objectives: to forecast thermal performances and to design palliative measures in urban space (Valenzuela Rubio 2009, Turégano Romero 2009, Gaja i Díaz 2009).

Two approaches can be distinguished in the studies of urban microclimate. The first is focused on finding better urban morphology to avoid unfavourable conditions. The second approach pays attention the thermal behaviour in the interstitial space in between buildings. This research convenes the second item, studying the elements that could be modified during urban renovation projects in order to improve microclimate conditions. Which are related as follows:

\section{Green areas in urban space}

Definitely, the first and most effective measure to reduce unfavourable microclimate conditions is the use of green areas and trees. The use of natural soil and trees has direct and indirect effects on urban climate. The direct effects are creating shades and wind protections, whilst plants evapotranspiration is considered as an indirect effect (Akbari et al. 2001, Fariña Tojo 2001, Giridharan et al. 2007, Higueras 2011, Mirzaei, Haghighat 2010, Ochoa De La Torre, J.M. 1999, Shashua-Bar, Hoffman 2002, Smith, Levermore 2008, Wong et al. 2010a, Wong 2007).

\section{Selection of finishing materials}

A second approach to reduce the negative effect of microclimate is to work on the horizontal surfaces of finishing materials: floors, streets, squares, parking and roofs; which represent the major horizontal surfaces in the city.

In recent years, studies pay attention to the use of cool materials. In roofs, the most widely used materials are those with high reflexivity and infrared emissivity that result in low surface temperature. For soils, different strategies can be chosen. The main one is based on the use of high reflective materials that reduce heat absorption. Other systems are based on the use of pervious materials where evaporation 
contributes to the temperature decreasing (Giridharan et al. 2007, Smith, Levermore 2008, Wong 2007, Mirzaei, Haghighat 2010, Karlessi et al. 2009, Synnefa et al. 2007, Synnefa et al. 2011, Santamouris et al. 2011, Akbari et al. 2001, Meyn, Oke 2009). Another alternative solution is the use of vegetation fin the building envelopment. Green roof adds several benefits:

- Solar protection due to shade effects provided by plants.

- Natural cooling due to plants evapotranspiration.

- High roof insulation thanks to large thermal mass produced by their drainage and soil layer. (Fioretti et al. 2010, Wong et al. 2010b)

The opportunity to use these strategies to improve the outdoor thermal performance of Madrid's suburban neighbourhoods has been studied. Different project scenarios have been evaluated and compared between each other, based on the simulation processes. The objective is to enhance the knowledge on thermal urban performance in order to propose urban passive design strategies.

\section{SELECTION AND ANALYSIS OF THE CASE STUDIES}

To study the microclimate effects on urban spaces, the thermal behaviour analysis of three real case studies located in the city of Madrid have been used. The city of Madrid is located in the central zone of the Iberian Peninsula at an altitude $667 \mathrm{~m}$ above the sea level, making it the highest capital city in Europe. The city is characterized by a temperate climate with hot-dry summers according to the Köppen classification for the Iberian Peninsula (Agencia Estatal de Meteorología, 2011).

The three case studies were identified within the district of Moratalaz. Moratalaz is a residential neighbourhood occupying the eastern suburban area of Madrid. It was raised in 1970 thanks to the public housing programs implemented after the Civil War. In those actions of public housing, a novel composition of superblock lot was employed. Wide pedestrian spaces blend with green areas around blocks with different heights and configurations,. The last 70s sprawl areas are distinguished by a very innovative urban organization for that time. It is based on a rational structure: residential buildings stand on pilotis open urban blocks, large landscaped areas in between buildings and the creation of tree-lined boulevards (Ardura et all. 2009, Tumini et all. 2010). Two study areas have been selected:

- Pavones: characterized by 5 storey buildings on pilotis of linear form and tall buildings over 11 floors; NE-SW oriented at an angle $27^{\circ}$ azimuth south. The free space is occupied by car parks, gardens and tree-lined boulevards.

- Fontarrón: characterized by 5 storey-tall buildings organized in open linear block in a courtyard distribution, with gravel areas and isolated trees. The orientation is NE-SW with an inclination of $48^{\circ}$ south (Figure 4 ). 

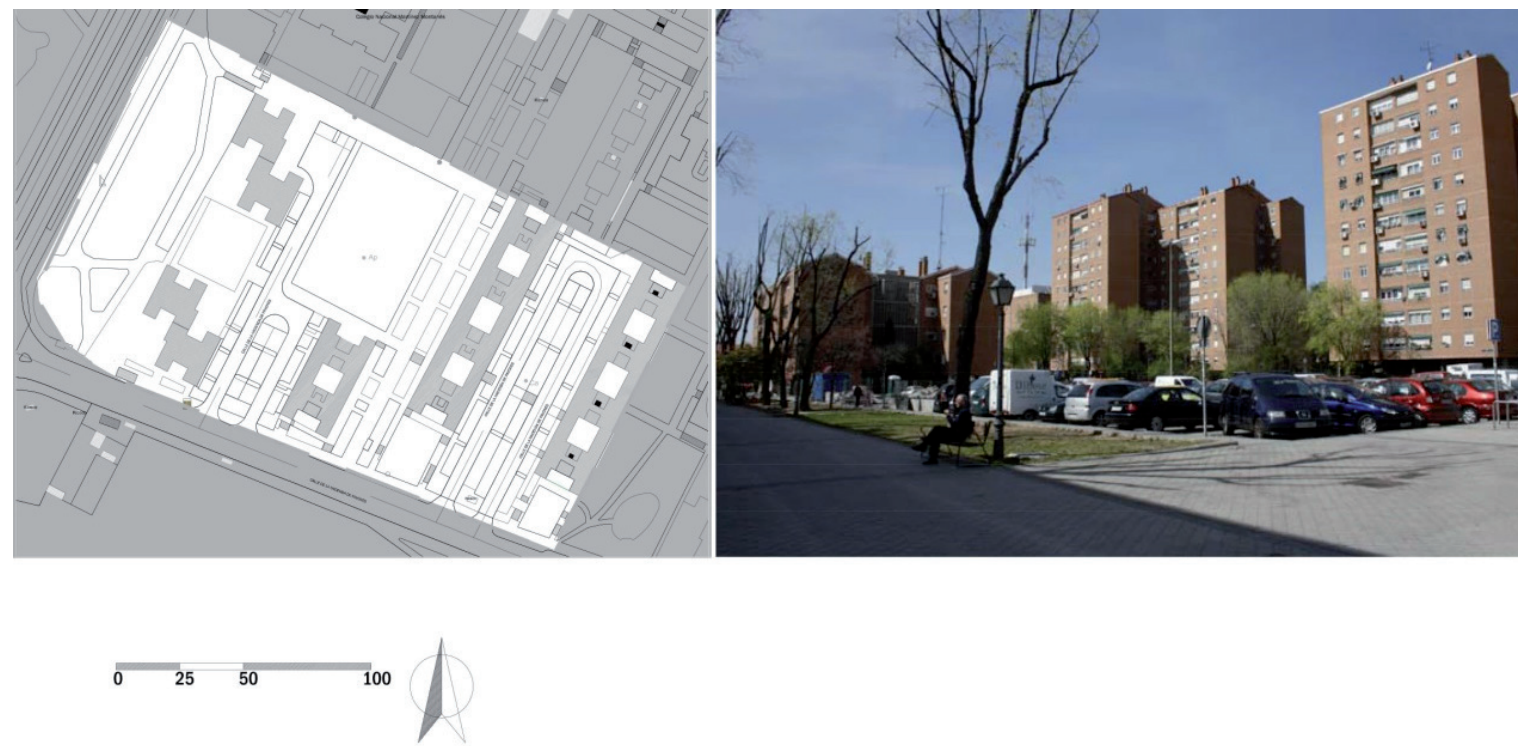

Figure 3. Mapping and picture of Pavones case study Madrid Source: compiled by the Author.
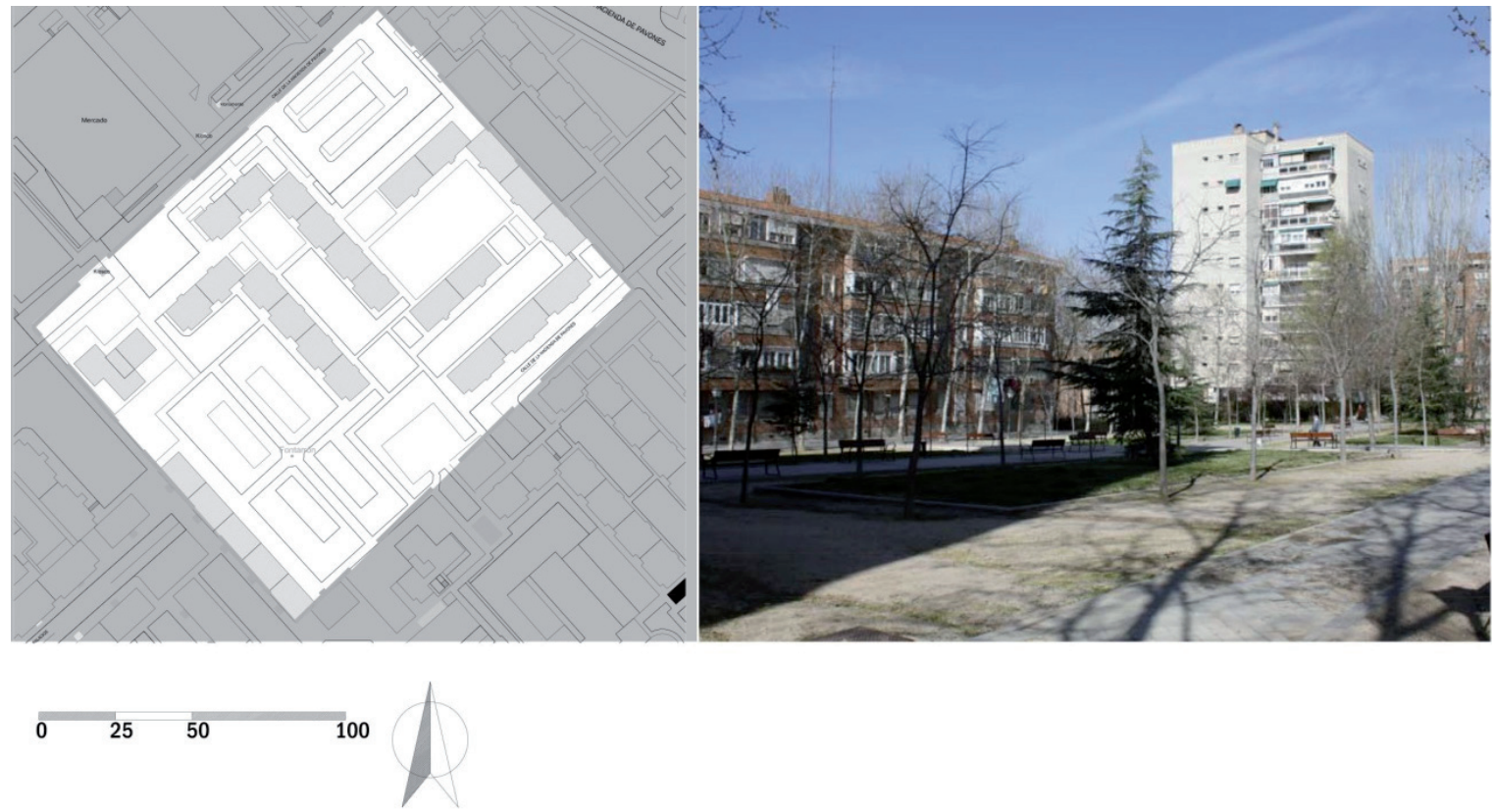

Figure 4. Mapping and picture of Fontarrón case study Madrid Source: compiled by the Author.

A third case study, located in a new urbanized area has been selected. The Horcajo area has an urban organization totally different from the earlier one: this is a courtyard block building typology, crossed by the Fuente Carrantona street with strong traffic density, streets between blocks of two-way with low density of traffic and with parking in lines (Figure 5). 

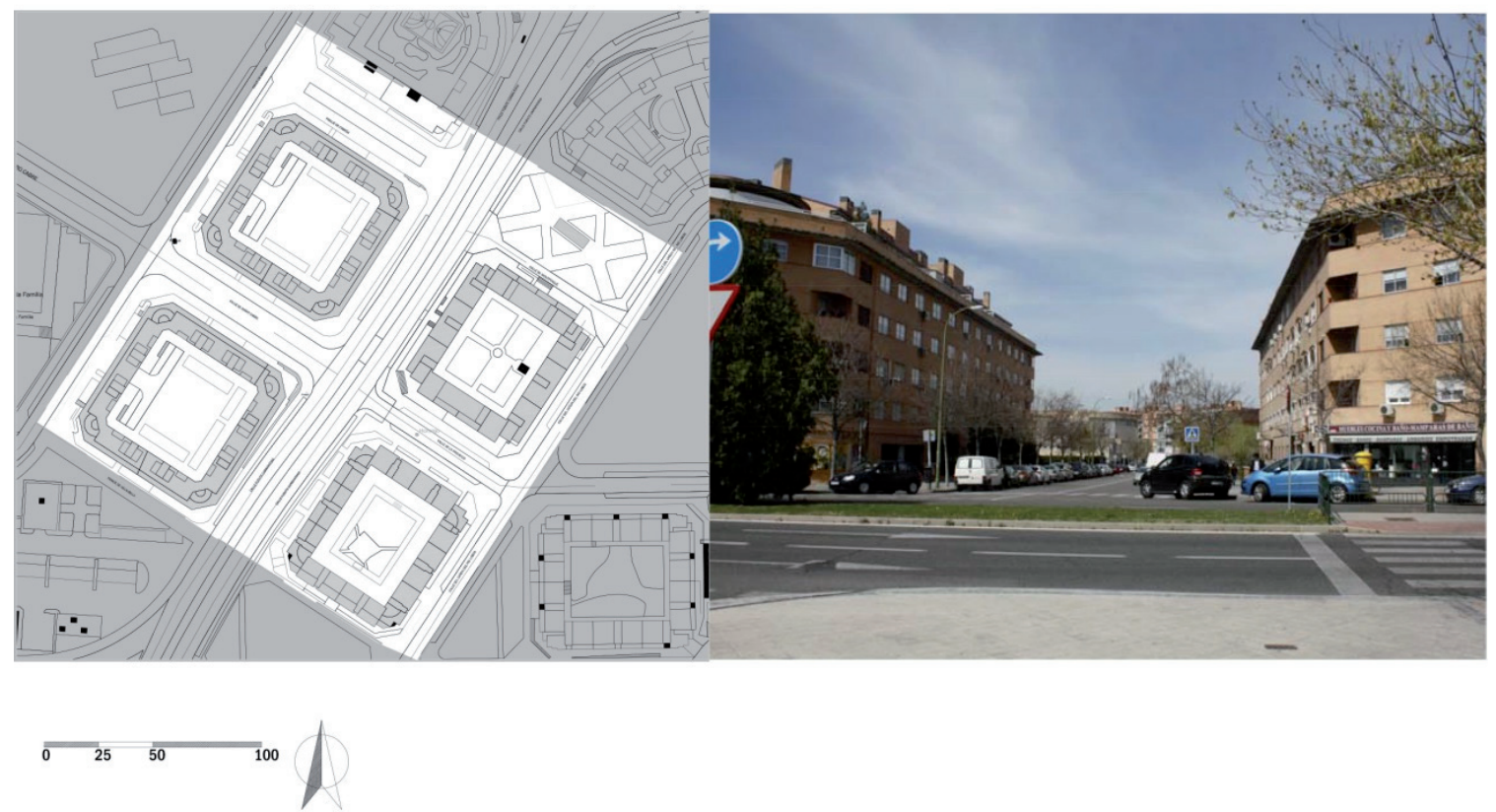

Figure 5. Mapping and picture of case study Horcajo, Madrid Source: compiled by the Author.

To describe the neighbourhoods, some of the indicators developed by Salvador Rueda for the Special Plan for Environmental Sustainability Indicators of Urban Development in Seville and for Victoria Mobility Plan, have been taken as reference (Rueda 2006).

Building Density: It indicates the number of dwelling per hectare. The main purpose of this indicator is to control the density of construction, in order to avoid the diffuse city spread and the congestion problems due to very high density.

Building Density $D(n / h a)=$ Dwelling $(n) /$ Total area $(h a)$

Absolute Compactness: It is expressed as a building volume per square meter of urban area. The value indicates the pressure of buildings in the grid of the city. It is the element which gives the idea of proximity: the ability to concentrate a lot of functions in a limited area.

Absolute Compactness C $(\mathrm{m} 3 / \mathrm{m} 2)=$ Building Volume $(\mathrm{m} 3) /$ urban area $(\mathrm{m} 2)$

Permeability index: The aim of this indicator is reduce impervious soil and to promote the natural water cycle. The filtration capacity is defined according to a coefficient related to the soil type, as can be seen in table 1.

The value is defined as IP: $\Sigma$ (area $x$ coefficient)/total area.

Percentage of roads: This indicator points out the attention to impact of the car on public space and other transport systems (bicycle and pedestrian). The indicator is expressed as follows:

Percentage of roads $(\%)=\sum$ road for motorized $(\mathrm{sm}) /$ total $\operatorname{road}(\mathrm{sm})$. 


\begin{tabular}{lcl} 
Surface & $\begin{array}{c}\text { Coef. } \\
\text { Impervious soil }\end{array}$ & $\begin{array}{l}\text { Surface description } \\
\text { Impervious to water and air without vegetation } \\
\text { such as asphalt, concrete slab and tiles. }\end{array}$ \\
\hline Partially impervious soil & 0,3 & $\begin{array}{l}\text { Soil pervious to water and air without vegetation } \\
\text { such as gravel or rocks. }\end{array}$ \\
\hline Semi-impervious soil & 0,5 & $\begin{array}{l}\text { Soil pervious to water and air, which allows } \\
\text { filtration, with vegetation such as sand, wood, slab } \\
\text { with loam. }\end{array}$ \\
\hline $\begin{array}{l}\text { Green area without } \\
\text { connection with natural soil }\end{array}$ & 0,5 & $\begin{array}{l}\text { Green roof or green area with a loam layer with a } \\
\text { thickness of less than } 80 \mathrm{~cm} \text {. }\end{array}$ \\
\hline $\begin{array}{l}\text { Green area with connection } \\
\text { with natural soil }\end{array}$ & 0,7 & $\begin{array}{l}\text { Green area with loam layer with thickness } \\
\text { exceeding } 80 \mathrm{~cm} \text {. }\end{array}$ \\
\hline $\begin{array}{l}\text { Green area on natural soil } \\
\text { Natural loam for flora and fauna growth }\end{array}$
\end{tabular}

Figure 6. Pervious coefficient relating to soil type

Source: Rueda, Indicadores de Sostenibilidad para el Plan de Sevilla. 2006.

Number of trees per built square metre: The intent of this indicator is to ensure the minimum number of trees in the urban area, according to the urban grid characteristic. This value should change with the urban typology. The indicator for the urban grid of suburban areas is calculated as follows:

Trees per sm: $n^{\circ}$ of trees/ area sm.

Relationship between Height and Wide: this is the most commonly used indicator to describe the urban morphology. The H/W ratio is the key element in the climate behavior since it influences: the solar radiation incoming (the SVF), the heat transfer for radiation and the convection in the canyon. The canyons analysis is shown in Figure 8. (See next page)

The following table presents the values obtained in these three case studies. The indicators evaluation is based on reference values, which are indicated in the last column below. The assessment is carried out according to the following scale: $\Delta$ good, $\leftrightarrow$ acceptable, $\boldsymbol{\nabla}$ unfavourable

\begin{tabular}{|c|c|c|c|c|}
\hline Indicator & Pavones & Fontarrón & Horcajo & Ref. \\
\hline Building Density (dw/h) & $\underset{\wedge}{66,67}$ & $\underset{\wedge}{142,58}$ & $\underset{\wedge}{102,65}$ & 60 \\
\hline Absolute Compactness (cm/sm) & $\begin{array}{c}3,94 \\
\nabla\end{array}$ & $\begin{array}{c}3,33 \\
\nabla\end{array}$ & $\begin{array}{c}4,87 \\
\leftrightarrow\end{array}$ & $5-7,5$ \\
\hline Permeability index (\% of sm/sm) & $\begin{array}{c}27 \% \\
\nabla\end{array}$ & $\begin{array}{c}23 \% \\
\nabla\end{array}$ & $\begin{array}{c}6 \% \\
\nabla\end{array}$ & $30 \%$ \\
\hline$\%$ of roads & $\begin{array}{c}57 \% \\
\nabla\end{array}$ & $\begin{array}{c}37 \% \\
\nabla\end{array}$ & $\begin{array}{c}59 \% \\
\nabla\end{array}$ & $25 \%$ \\
\hline Trees number per built sm & $\underset{\nabla}{0,09}$ & $\underset{\nabla}{0,15}$ & $\underset{\nabla}{0,07}$ & $1 \mathrm{t} / 20 \mathrm{sm}$ \\
\hline
\end{tabular}

Figure 7. Assessment indicators for the three case studies Source: compiled by the author.

Excluding these first indicators of urban density, the remaining four have values below the recommended by Rueda, showing a poor environmental quality for these urban areas. 

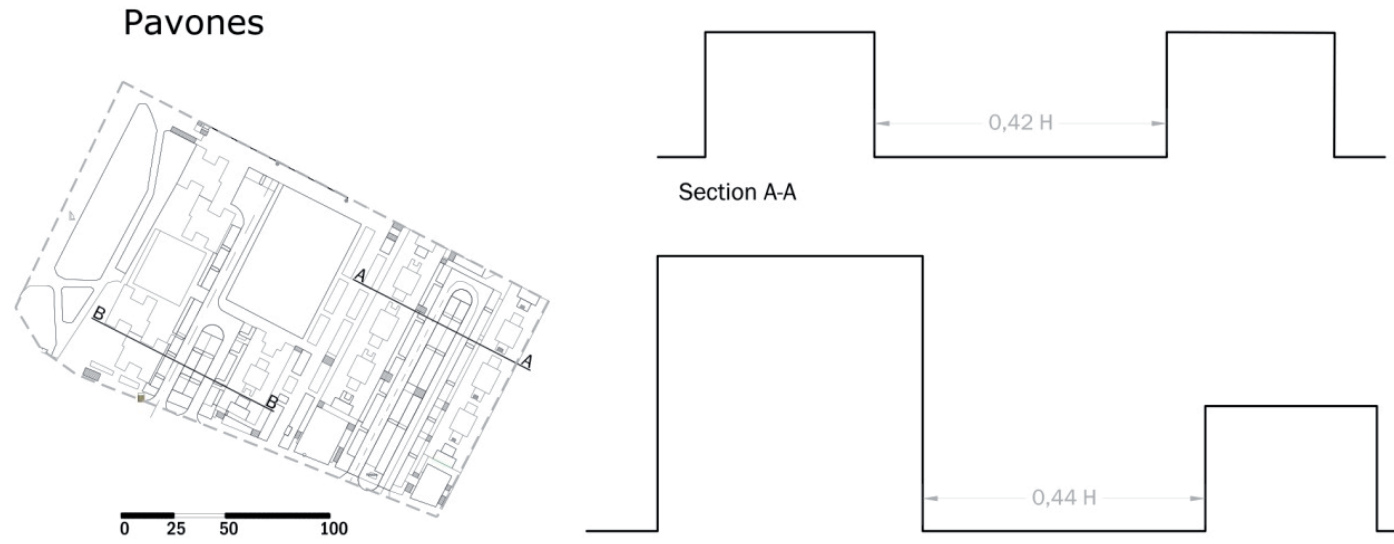

Section A-A

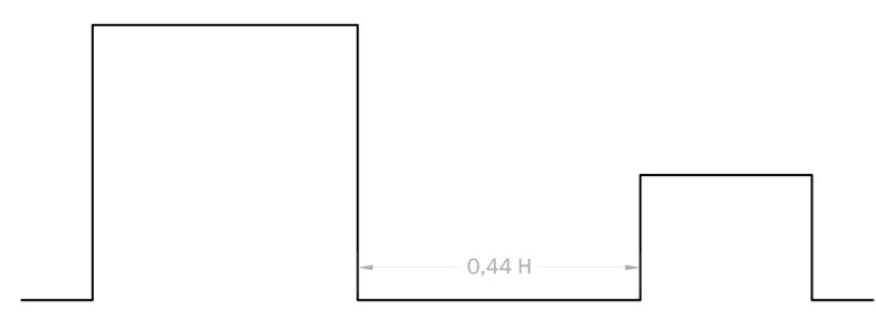

Section B-B

\section{Fontarrón}
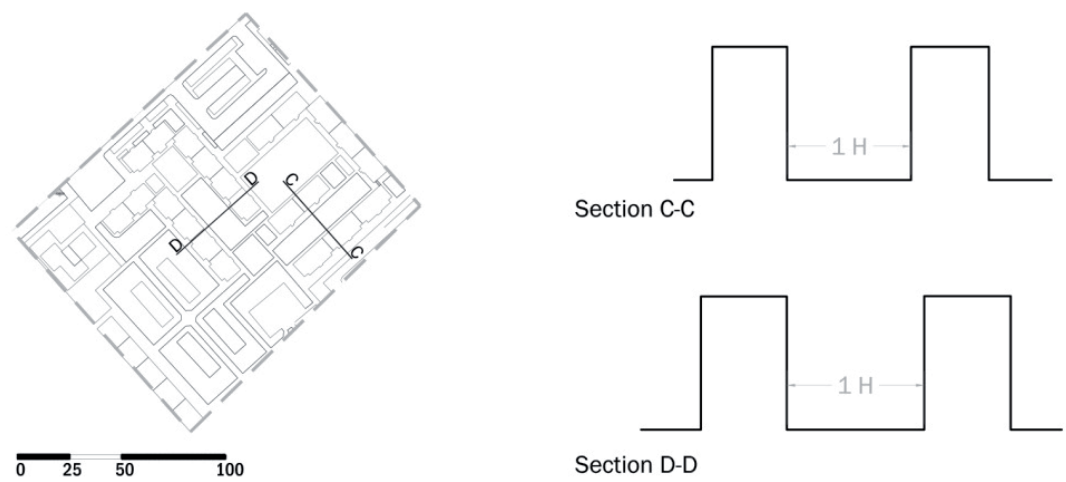

\section{Horcajo}
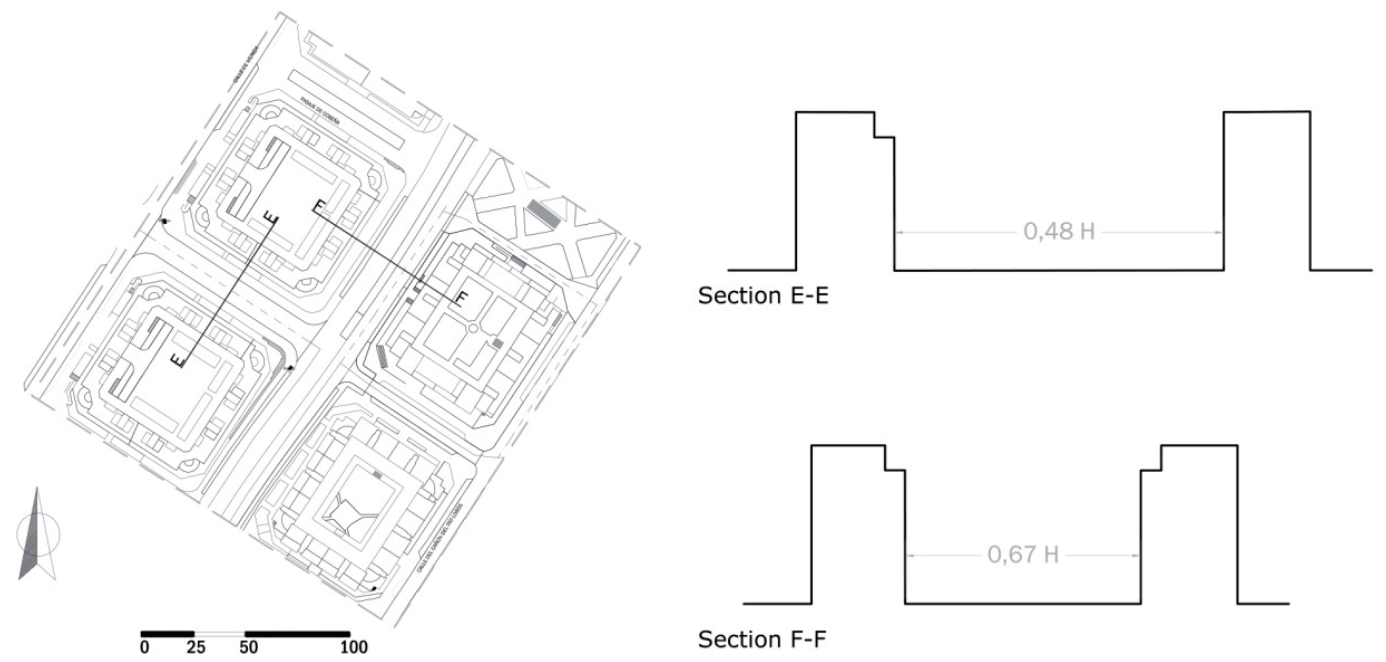

Section E-E

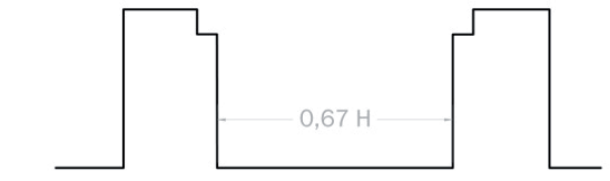

Section F-F

Figure 8. H/W analysis of Urban Canyon in the case studies Source: compiled by the author. 
The analysis of indicators, one by one, shows that the rationalist urban typology, with block buildings and lots of green space, may also allow higher densities, although the compactness will drop significantly. This shows that the pressure of buildings on the territory is very high.

In the case of Horcajo courtyard building typology, high density and high compactness was observed, however it is heavily lacking of biodiversity, the amount of green areas and soil permeability.

All three areas have a high percentage of roads, highlighting the dominance of the car over other transport systems.

The value that is far below the recommendations is the one that relates to the number of trees. It is not trustworthy, if not impossible; to achieve these values, because they should multiply by 10 the number of trees. Therefore, doubts on the applicability of these ranges to urban areas have been raised. Such a large number of trees would entail very low built density, very low compactness and high maintenance costs for irrigation and green spaces management.

The indicator analysis has allowed the characterization of three case studies and the definition of some critical issues. The indicator system therefore has the dual function of describing the area and guiding the design strategies in the project of urban regeneration.

This research includes a design methodology based on the comparison of different project scenarios. The calculation of the microclimate is achieved by using the methods of analytical calculation based on fluid dynamics concepts and radioactive budget in urban spaces.

\subsection{Use of numerical method}

From initial conditions determined by the current state of the case studies, there has been a numerical model that, through the use of IT tools has allowed the simulation of thermal behaviour and fluid-dynamic space. Different hypothetical scenarios have been performed by changing only one parameter from the initial model in each of them.

The microclimate can be analysed exclusively in terms of energy budgets in order to understand how energy flows that can be modified through open space designs. The energy balance of the Earth surface and the ambient air in the urban environment by the energy gain and losses, can be expressed as Energy gains=Energy losses + Energy storage (Figure 9) (Santamouris et al. 2001).

There are different approaches to modelling the climate of cities; the selection of numerical models involved the time and the length scale. The length scale for example can vary from a few metres to a few kilometres, and timescale from a few seconds to seasonal variations lasting months. It is practically impossible to solve all the scale in a single model with the present computational power available. Despite this, the use of computer allows to solve de differential equations numerically with appropriate boundary conditions, pressure and temperature profile on a predefined numerical grid (Robinson 2011). 


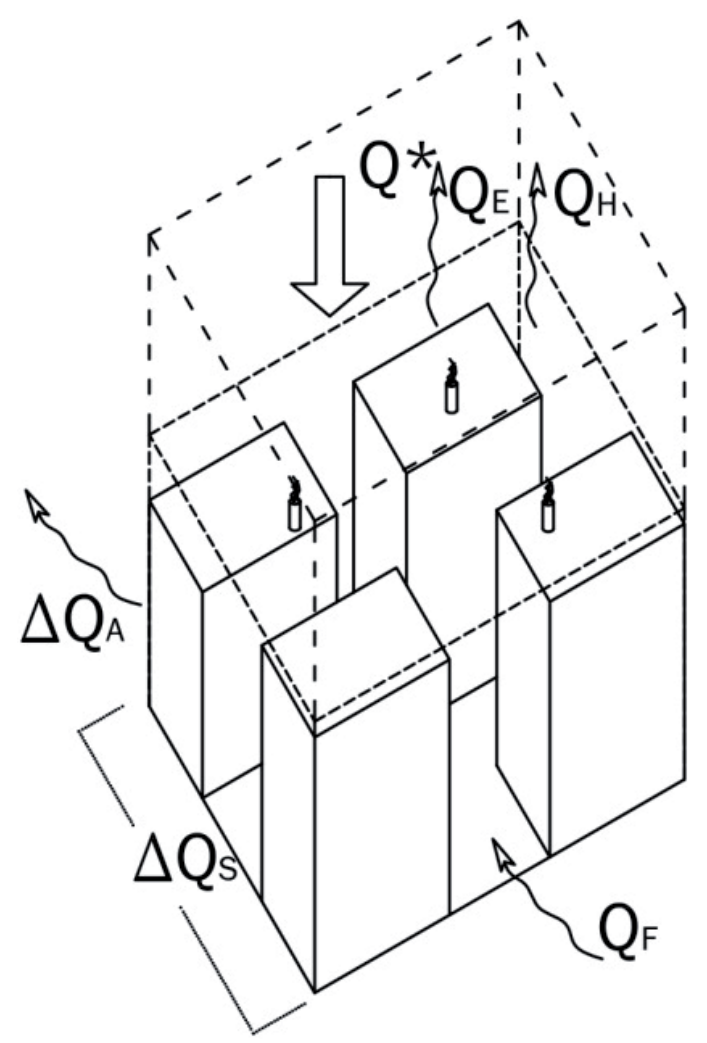

Figure 9. Schematic presentation of the energy fluxes in the urban environment Source: (Santamouris et al. 2001) elaborated by Author.

The simulation process is carried out with different calculation software: ENVImet 3.1. used for the determination of weather parameters, ECOTECT Analysis 2010 to calculate the Sky View Factors and solar radiation, Microsoft Excel to data elaboration and other as Autocad, Sketchup and Photoshop for the realization of 3D models and representation.

The software ENVI-met has been developed by Michael Bruse (2009) (Institute of Geography, Department of Geoinformatics, Environmental Modelling Group, University of Mainz) to simulate the interaction between surface-plant-air in an urban environment, based primarily on models of fluid dynamics and thermodynamics. The tool has been developed to allow the analysis of the effect of small scale changes in urban design (pattern, vegetation, building morphology, etc.) on microclimate under mesoscale conditions defined at the beginning (city climax, meteorological data, etc.). The basic concept of the analysis system is given by non-hydrostatic incompressible Navier-Stokes equations. The turbulence closure is based on the standard $E-\varepsilon$ model (Launder, Spalding 1974) that calculates the turbulent kinematic energy (E) and its dissipation rate $(\varepsilon)$.

All of these prognostic equations are extended to the vegetation which take into account mainly the LAD (Leaf Area Density) and the gradient of the involved variables (wind speed, humidity or temperature) (Figure 10) (Bruse 2004, Bruse, Skinner 1999, Bruse, Fleer 1998a). 


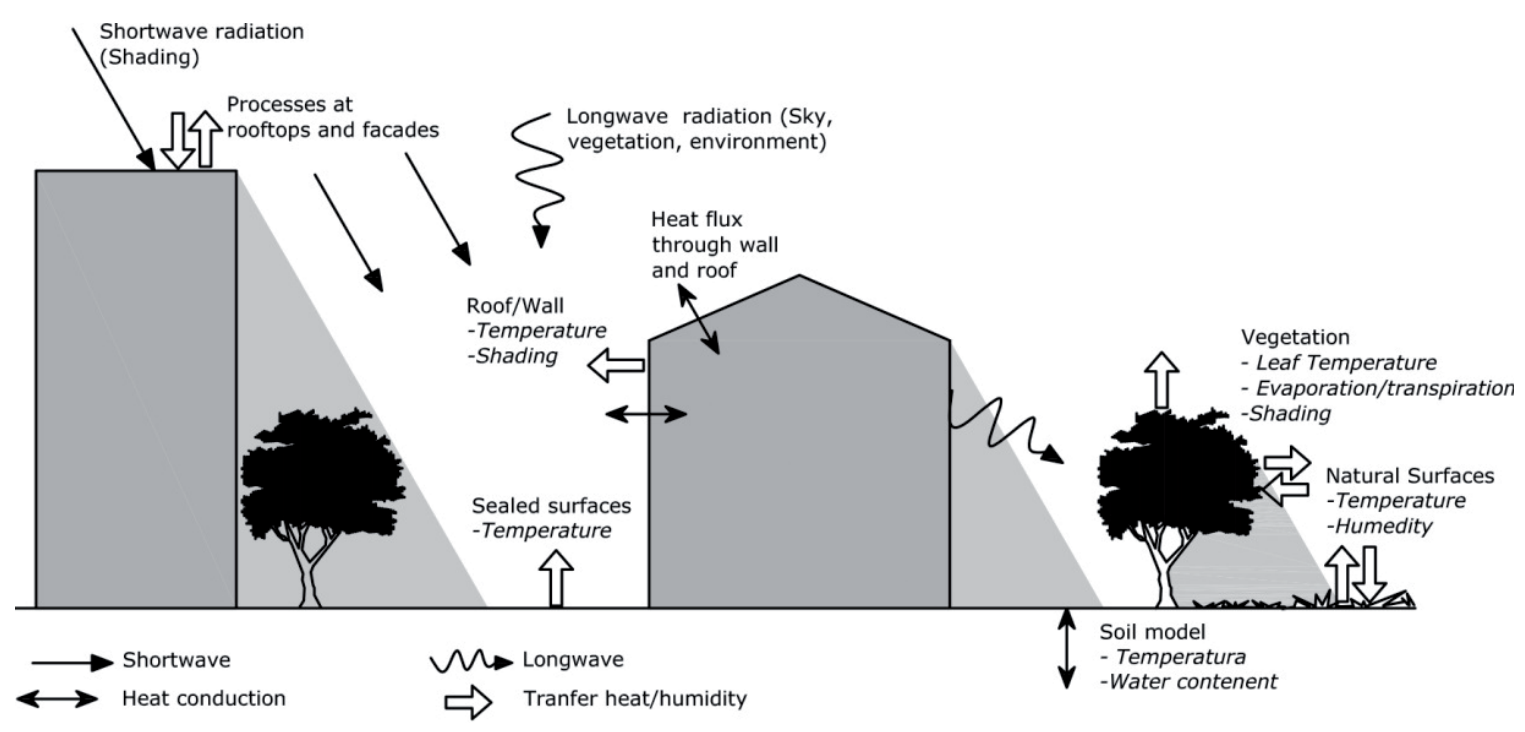

Figure 10. Envi-met model interaction between atmosphere and urban surfaces Source: (Bruse 2003) elaborated by Author.

The main advantages in the application of this system are:

1. Simplicity of use and low demand of time in the use of software,

2. A good representation of the transfers between vegetation and soil surface with a multilayer configuration,

3. The possibility of using a small horizontal and vertical grid with a precision up to 1 meter,

4. Existence of a low number of input parameters for the whole system vegetationsoil-atmosphere.

(Ali-Toudert, Mayer 2006, Bruse, Fleer 1998b, Hassid et al. 2000, Meyn, Oke 2009) At the same time a 3D model has been performed by software ECOTECT Analysis 2010 in order to analyse and characterize the case studies. The analysis with ECOTECT has been limited to the radioactive component. ECOTECT is a next generation software that links design program to a performance analysis and features for simulation energy, lighting, thermal, acoustic, analysis of solar and environmental impact. The tool has two purposes: to assist in the design phase, allowing the evaluation from the early stages of design, and to evaluate the final performance of the executive design.(Marsh 2010)

\subsection{Description of simulation model}

Below, a detail of the procedure to build the calculation models will be given. The software allows the user to define: 
- The mesoscale conditions by the indications of geographic location and meteorological settings;

- The geometry of model environment such as building, plant or soil detail;

- Simulation start date and time, time of simulation and time interval to write the model state.

The model domain is organised as a rectangular area which extends in $\mathrm{x}-, \mathrm{y}-$ and $\mathrm{z}-$ direction. The dimension and resolution of the grid should be defined by the user in accordance with the objective of simulation. The vertical grid could be equidistant or telescopic.

In this research work the real morphology of case studies, with extension between 2 and 4.5 hectares, has been overlapped on a square grid of size $d x=3 m, d y=3 m$, $\mathrm{dz}=3 \mathrm{~m}$ thus creating an equivalent model for the simulation.

The program allows the user to define buildings in plan and elevation, assigning the following features:

- Inside Temperature [K] $293\left(20^{\circ} \mathrm{C}\right)$

- Heat Transmission Walls $\left[\mathrm{W} / \mathrm{m}^{2} \mathrm{~K}\right] \quad 1.94$

- Heat Transmission Roofs $\left[\mathrm{W} / \mathrm{m}^{2} \mathrm{~K}\right] \quad 0.6$

- Albedo Walls 0.2

- Albedo Roofs 0.3

The simulations were performed using tipical conditions of summer and winter, simulating the results 24 hours every 180 minutes. In order to set the start climate data, the value recorded on 21 December 2010 (winter conditions) and on the 15th of August 2011 (summer conditions) from Madrid-Retiro meteorological station of the Spanish National Agency of Meteorology (AEmet) has been used.

For the evaluation of the case studies a first simulation during 24 hours, with time steps of 180 min, was carried out in order to compare the results with the values measured in situ. This initial study was also essential to identify the most critical hour during the day with respect to comfort conditions. It corresponds at the 15:00 hour in summer condition. The most critical condition has been used for the evaluation and comparison of numerous hypothetical project scenarios.

This choice was dictated at the first because the need to obtaining a hypotheses result easily comparable each other. Then because the mitigation of maximum discomfort conditions is essential (Candas 2005, Mirzaei, Haghighat 2010). 


\section{SIMULATION RESULTS}

\subsection{Case study simulation}

The description of the results obtained by the simulation is presented below. As regards calculation with ENVI-met, the results are displayed through the use of LEONARDO software that allows obtaining maps in which the values of temperature, wind speed and direction and isolines of relative humidity has been indicated. For a better interpretation of results, the three areas are described by means of schedules that contain (figure 11):

\section{Step 1. Simulation with Autodesk Ecotect Analysis 2010}

The 1.a shows the Orthophoto map of area and localization of case study. The image 1.b is the view of 3D model using for the simulation of the component of solar radiation and $\mathrm{SVF}^{3}$. In this model are defined the morphology of buildings, square and street and the position of trees. Materials properties are not introduced in this model. In the 1.c the Stereographic view of Sky View Factors is presented. The fish-eye photo shows the sky exposition and the year's sun path, so it is possible to know the exposition of the area at different times of year. The blue point identifies the sun position at $15^{\text {th }}$ August at 3:00 p.m. The results of the calculation has been reported in the comment box. The analysis of solar direct radiation has been in picture $1 \mathrm{~d}$. The simulation has been carried out in summer conditions and shows the amount of solar direct incident radiation in the case study area, taking into account distribution and morphology of buildings, and the presence of trees.

\section{Step 2. Realization of 3D model with ENVImet 3.1}

Image 2.a shows the Orthophoto map of the case study area. The model plan view is presented in image $2 \mathrm{~b}$. The model is organized in a $3 \times 3 \mathrm{~m}$ square grid; the arrangement and morphology of buildings are defined in 3D space; are also defined: the location and type of vegetation and soil finishing materials.

\section{Step 3. Presentation ENVI-met simulation results}

2.c is the plan view of climate simulation, the section plane is located at $1.2 \mathrm{~m}$ above the ground: this height is representative for the study of the occupants' comfort perception. The temperature is shown in the colour map; the vectors represent the wind direction and intensity, whilst the contour lines indicate the value of the relative humidity. In image 2.e the simulation results are shown in vertical section view. In table 2.d the maximum and minimum values recorded in the area are also displayed. The comparison between the maximum and minimum values gives us an area gradient, therefore, a vision of microclimatic variability. A different performance between winter and summer can be observed, the results show more homogeneous

\footnotetext{
${ }^{3}$ SVF. Sky View Factor
} 
condition in winter compared to summer. At the same time, it is possible to compare these different case studies and see which ones have more homogeneous performance and those in which the microclimatic conditions are very different. A general observation of the climate simulation result of each case study is described in the same schedule as seen in table 2.1.

\section{Step 4. Analysis of simulation result throughout a detailed view of different parts of the case study}

The detailed view of a singular zone of the case study is shown in image 3.a, plan view; and in 3.b: vertical section view. In box 3.c there is a brief description of a singular zone case study. Table 3.d shows the climatic data calculated in the measurement point. The measurement point is identified by $(x ; y)$ coordinates, related to the model's grid, and graphically in the plan view. The observation relating to the climatic performance of the zone is detailed in the 3.e box in figure 11 below.
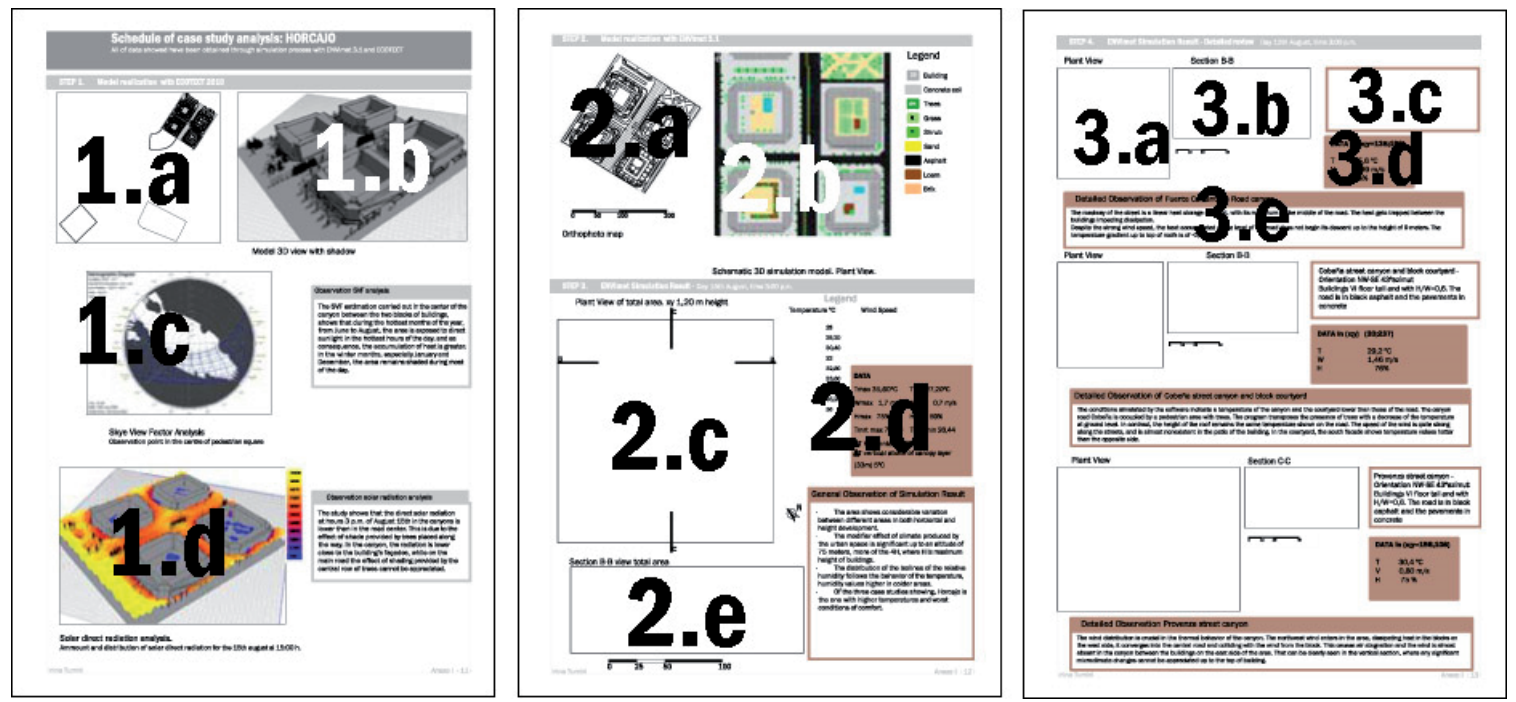

Figure 11. Schedules layout of case study analysis.

Source: compiled by Author.

The analysis of 3 case studies has been carried out for summer (step 3. and step 4.) and winter conditions (step 5. and step 6.). See Annex I for further details.

\subsection{Validation of the simulation model}

The review of climatic values obtained shows that the program has some limitations in simulating Madrid climatic conditions. In this comparison between the values of the simulation and the mean monthly values measured by the meteorological station the main incongruence is recorded in the relative humidity percentages that are higher than the real values. The comparison between simulating values and data collected by the Retiro meteorological station (AEMET) as can be seen in graphs in Figure 12. The main characteristics are described as follows: 


\section{Summer:}

- Temperatures are similar, although the minimum values are more uniform.

- Minimum temperature of the simulation is recorded at 6 a.m., two hours earlier than the real values.

- The maximum temperature recorded in the measurement is at $7 \mathrm{p} . \mathrm{m}$. while the output of ENVImet is at 3 p.m.

- The relative humidity obtained from the simulation program is higher than average values collected in the month of August.

Winter:

- The simulation temperature is lower than the measurement data.

- The simulation trend is not similar to the measured data trend, especially the highest temperature peak at 9 a.m.

- The relative humidity of the simulation program is significantly higher than real conditions.

The temperature profile clearly shows that, whilst in winter there is no connection between the simulated value and the real condition, in summer these two values have the same trend. These differences are related to a problem in the definition of winter condition of Madrid "default climax" used by ENVI-met. Unfortunately this software version does not allow any review or change of these climate conditions. Regarding the effectiveness of the simulation tool is possible to conclude that the results obtained can be considered applicable for the implementation of research since:

- It is limited to the summer conditions observations in relation to the maximum temperature

- The values obtained should not be taken as absolute values, although the comparison of scenarios.

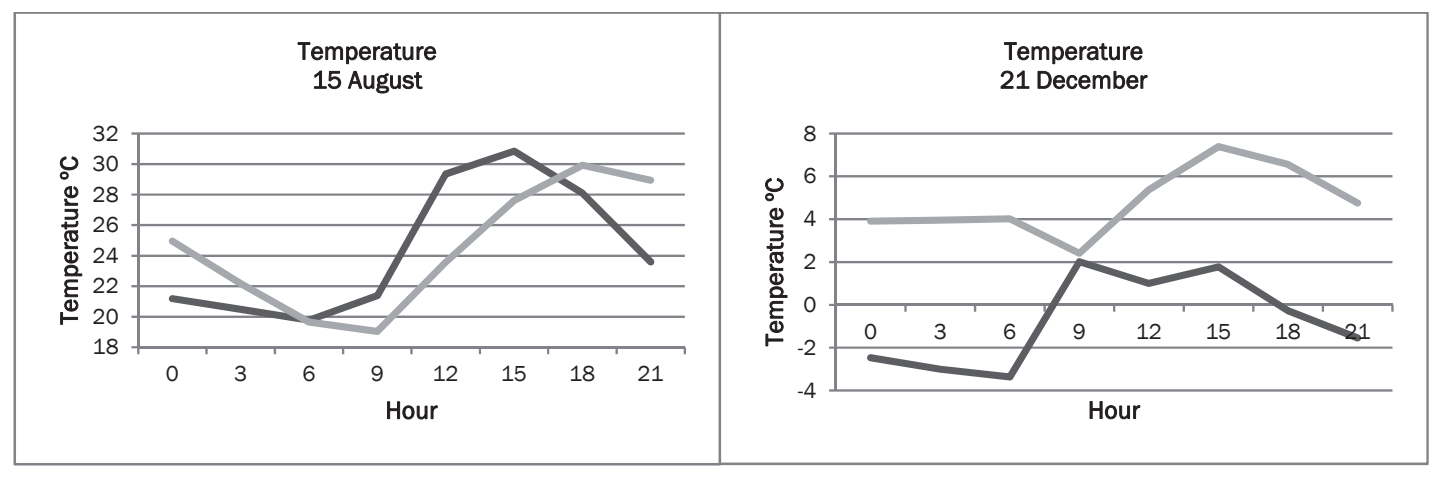

Legend: Simulated $\quad$ Measured

Figure 12. Comparison between the values obtained from the simulation and the monthly average values for winter and summer condition.

Data Source: Air Quality System of Madrid and the author 


\subsection{Discussion of Case Studies Analysis}

In the simulations performed in the three cases (Annex I), common elements can be observed:

- The urban environment creates microclimatic areas with outstanding features in the summer conditions. The most probable explanation is that the software places great emphasis on the effects generated by solar radiation in summer and very little in winter. The literature indicates that the effect of heat island in Madrid is more pronounced in winter (López Gómez et al. 1991). Take emphasis that the remote sensing of urban heat island is an study of urban space to the mesoscale level where many factors, amongst other anthropogenic inputs and the temperature inversion effect, have to be taken into account. Those factors are not considered at the microscale level. However, to improve the calculation method applicability to Madrid's climate, further study of the default climate using a simulation process is recommended.

- In spaces with dark colour impervious surfaces (asphalt), such as roads and parking, the heat storage take place, and it is more intense during summer. The result shows that the system is sensitive to the soil type, thus the tool can be used to support the materials selection

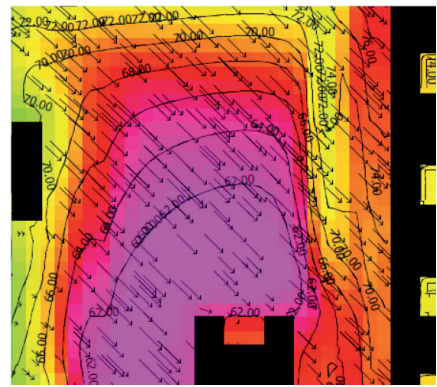

A

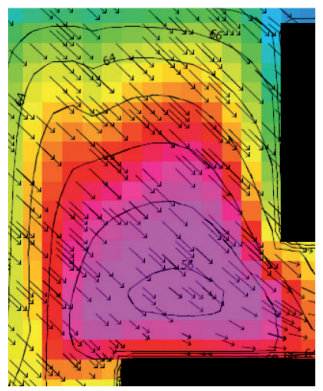

B

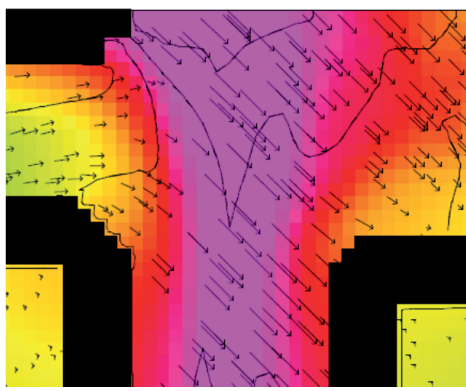

C

Figure 13. View of zone with dark asphalt soil in Pavones (A), Fontarrón (B) and Horcajo (C). The results highlight that in areas with dark soil the temperature is higher.

Source: Compiled by author. Elaborated with ENVImet 3.1.

- In open areas such as parking, heat dissipation occurs at low heights; while in canyons between buildings, heat dissipation capability depends on many factors: $\mathrm{H} / \mathrm{L}$ ratio, wind speed, orientation and exposure.

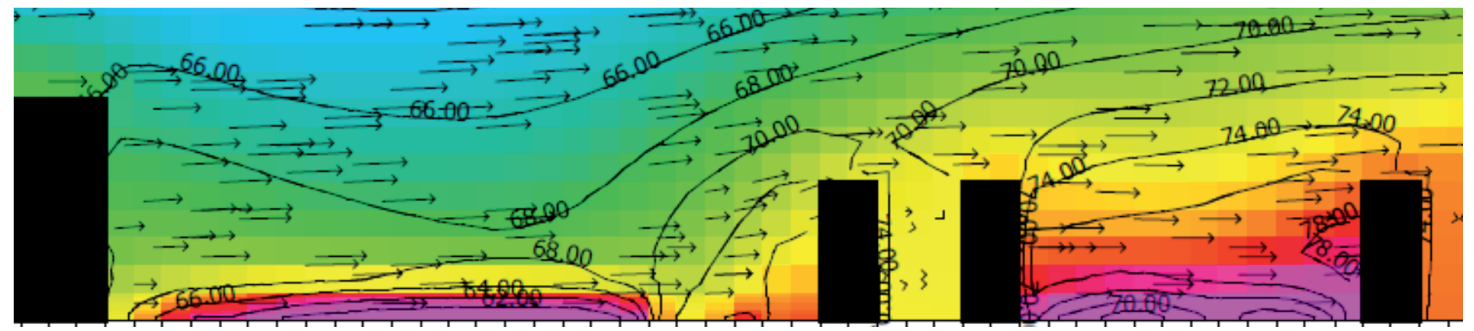

Figure 14. View of vertical section of Pavones case study.

Source: Compiled by author. Elaborated with ENVImet 3.1. For further details see Annex 1. 
- Green areas, especially with tall trees, are those where lower temperatures, higher humidity and mild winds are registered. The mitigating effect of vegetation is more relevant in summer. This result also seems coherent with the real behaviour of outdoor urban space because in winter the effects of shading and evapotranspiration produced by trees, which are mainly deciduous, are lower than in summer.

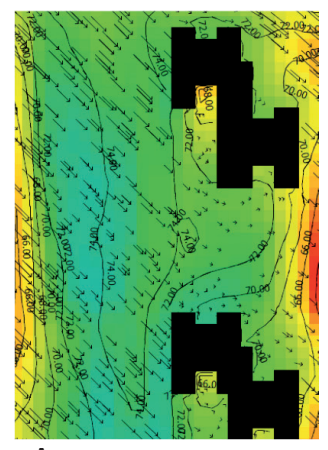

A

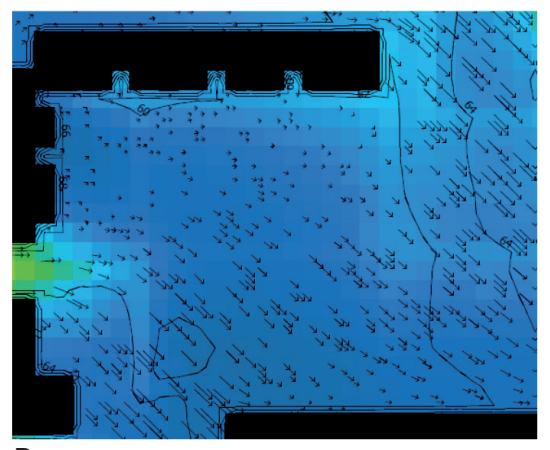

B

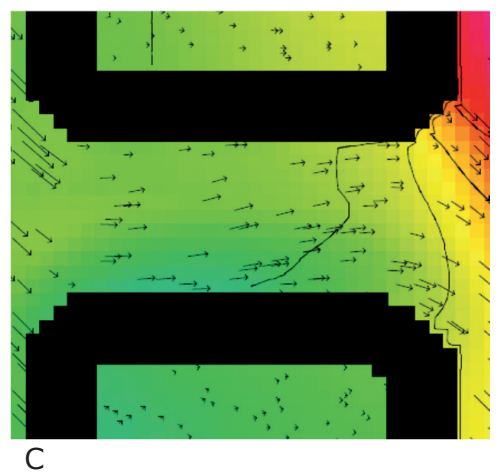

C

Figure 15. View of green areas of Pavones (A), Fontarrón (B) and Horcajo (C). Source: Compiled by author. Elaborated with ENVImet 3.1. For more details see Annex I.

The most significant differences between these three case studies are related as follows:

- Horcajo shows higher temperatures and most nonhomogeneous conditions between microclimatic zones, on the other hand, Fontarrón the least. The simulations show that the urban morphotypology of courtyard buildings creates unfavourable microclimate, with areas with significant thermal discomfort and where the trees along the roads do not produce the expected climatic mitigation effect. A rationalist urban typology, with buildings blocks, large use of pervious soils and use of vegetation on the free space between buildings, as Fontarrón, which shows better climatic conditions with wide cool zone in summer.

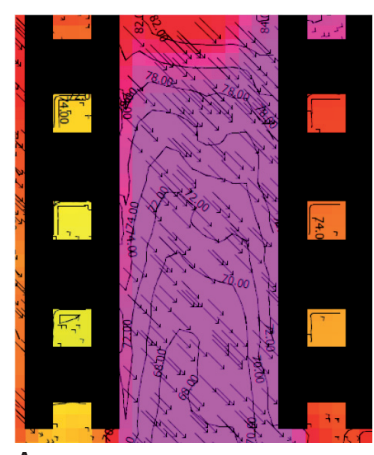

A

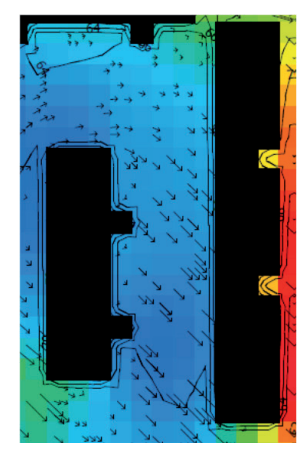

B

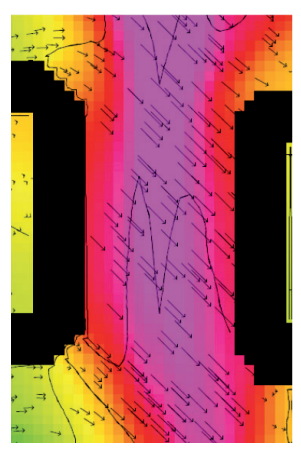

C

Figure 16. Example views of canyon in all case studies in summer conditions of: Pavones (A), Fontarrón (B) and Horcajo (C).

Source: Compiled by author. Elaboration made with ENVImet 3.1. For further details see Annex I. 
- In the canyons in between buildings with many trees there are no heat storage. Unlike what is observed in Horcajo and Pavones summer simulation results, the case study of Fontarrón shows that the free space between buildings are like an oasis of cooling.

- The analysis of the vertical sections shows that in Pavones and Fontarrón the urban space has a recognizable influence on the microclimate around to a height of $2 \mathrm{H}$, Horcajo up to $4 \mathrm{H}$. The sections show that in both cases, with open block building type, with differences between cases and between winter and summer conditions, heat dissipation mainly happened under buildings roof. The third case, a type of courtyard building, shows as well, a greater accumulation of heat in correspondence with the avenues, on the other hand the temperature descent occurs just surpassed the top of roof.

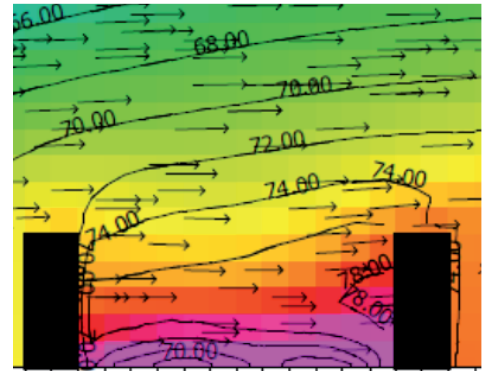

A

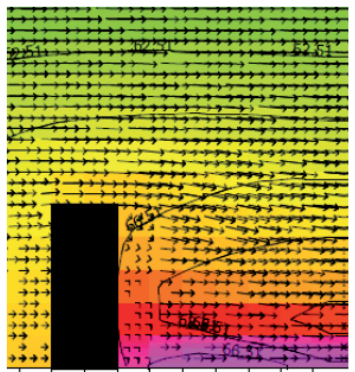

B

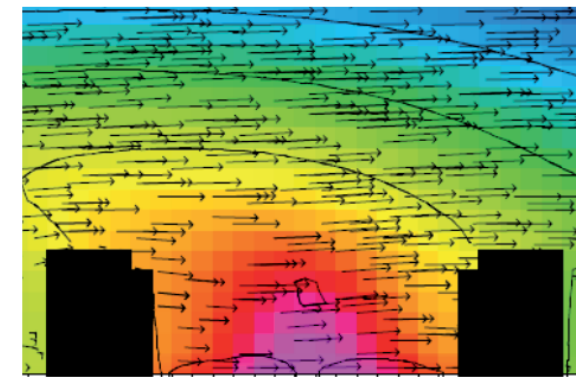

C

Figure 17. Vertical section of the canyon in the 3 case studies in summer conditions of :Pavones (A), Forntarrón (B) and Horcajo (C). Elaborated with ENVImet 3.1. For more details see Annex II

Source: Compiled by author. Elaboration made with ENVImet 3.1. For further details see Annex I.

In the simulations a direct relationship between climate performance and characterization indicators of the case studies ${ }^{4}$ cannot be observed. That occurs because the urban space performance is not only influenced by the amount of vegetation or building volume, but also by its spatial organization. For instance, Horcajo displays very different conditions from the other two cases, but the characterization indicators values are quite similar.

Take emphasis on: different thermal behaviour of the case studies in height, on heat accumulation in the canyons, and on heat island effect influence above the height of the Urban Boundary Layer (UBL) ${ }^{5}$. Regarding this first phenomenon, the major avenues are an important point of heat storage, which is hardly dissipated. In the Horcajo case study in Fuente Carrantona street, the heat storage causes a temperature rise of about $4^{\circ} \mathrm{C}$ in summer and $2.5^{\circ} \mathrm{C}$ in winter up to the roof height of the buildings. This phenomenon not only involves comfort in outdoor spaces but also the building energy consumption of buildings. With reference to the second aspect mentioned before, the simulations show that the heat island influence

\footnotetext{
${ }^{4}$ See the case studies characterization indicator described previously.

${ }^{5}$ Urban Boundary Layer. Start from rooftop and treetop level and extend up to the point where urban landscapes no longer influence the atmosphere (Wong 2007).
} 
dimension in courtyard buildings, is twice as height as the open block building typology This statement has important implications: i) at microscalar level on energy consumption and on open spaces comfort and ii) at mesoscalar level causing air pollution, particle concentration and photo-oxidation ${ }^{6}$.

Before carrying out the scenarios study, the comfort conditions in the three case studies were analysed throughout the entire day, in summer and winter conditions, with the aim to determine the most unfavourable conditions. The study of project scenarios will be based on the effects produced in the most unfavourable conditions in order to propose countermeasures for discomfort.

In order to evaluate the thermal comfort, the Universal Thermal Climate Index (UTCI) (Jendritzky et al. 2012, Bröde et al. 2012b, Bröde et al. 2012a, Havenith et al. 2012, Fiala et al. 2012) has been used. The UTCI is developed by the research activities compiled by COST Action 730, with the main objective of developing one internationally recognized model. It is based on physiological model that can describe thermal comfort condition in outdoor spaces and it can be available for different types of applications such as: urban planning, climate therapy, warning systems, tourists information, etc.(Jendritzky et al. 2012).

From studies based on different levels of comfort, UTCI have shown the best way to achieve the research objectives defined at the beginning: analysis of outdoor spaces, microclimatic aspects mainly related to a user and establish minimum quality ranges. The index allows the calculation of comfort conditions using climate values obtained from in situ measurements or analytical calculation. The UTCI follows the Equivalent Temperature (ET) concept, which involves an environment reference at $50 \%$ relative humidity (vapour pressure is capped at $20 \mathrm{hPa}$ ), in addition, air and radiant temperature equal air temperature (Bröde et al. 2012b). The physiological response has been calculated for a single person, considering clothing insulation after 30 and $120 \mathrm{~min}$ of exposition. This person is assumed to walk at $4 \mathrm{~km} / \mathrm{h}$ on ground level, the rate of metabolic heat production was assumed to be 2,3 MET $\left(135 \mathrm{w} / \mathrm{m}^{2}\right)$ (Fiala et al. 2012, Knez, Thorsson 2006, Knez et al. 2009, Kántor, Unger 2011, Bröde et al. 2012a). The UTCI equivalent temperature for a given combination of wind, radiation, humidity and air temperature is then defined as the air temperature of the reference environment that produces the same strain index value. As calculating the UTCI equivalent temperatures by repeatedly running the thermoregulation model could be too time-consuming for climate simulations and numerical weather forecasts, a fast calculation procedure has been developed and made available in the COST Action 730 web-page (http://www.utci.org/) (Jendritzky et al. 2012). The use of a numerical indicator makes the evaluation more objective. The value of the UTCI

\footnotetext{
6 Photo-oxidation. Secondary air pollutants, such as nitrogen dioxide $\left(\mathrm{NO}_{2}\right)$ and ozone $\left(\mathrm{O}_{3}\right)$, formed as a result of reaction between air pollutant as nitrogen oxidant (NOx) and volatile organic compounds (VOCs) and other naturally occurring constituents present in the air(Polidori 2006).

7 The UTCI is defined as the air temperature $(\mathrm{Ta})$ of the reference condition causing the same model response as the actual condition. The deviation of UTCI from air temperature depends on the actual values of mean radiant temperature (Tmrt), wind speed $(w)$ and humidity $(H)$. It may be written in mathematical terms as:
}

(Bröde P. el all. 2011) 
provides a numeric index measure of the thermal sensation and a rating scale as a benchmark. The UTCI is categorised in term of thermal stress ranking. The assessment scale is shown in Figure 18.

\begin{tabular}{|c|c|}
\hline UTCI $\left({ }^{\circ} \mathrm{C}\right)$ range & Stress Category \\
\hline above +46 & extreme heat stress \\
\hline+38 to +46 & very strong heat stress \\
\hline+32 to +38 & strong heat stress \\
\hline+26 to +32 & moderate heat stress \\
\hline+9 to +26 & no thermal stress \\
\hline+9 to 0 & slight cold stress \\
\hline 0 to -13 & moderate cold stress \\
\hline-13 to -27 & strong cold stress \\
\hline-27 to -40 & very strong cold stress \\
\hline below -40 & extreme cold stress \\
\hline
\end{tabular}

Figure 18. UTCI Assessment Scale: UTCI is categorized in terms of thermal stress.

Reference: Glossary of Terms for Thermal Physiology (2003). Journal of Thermal Biology 28, 75-106 (http://www.utci.org)

The following tables show the results of simulation observed in the three cases in three different observation points during 24 hours. The results are shown by steps of 3 hours.

Pavones: parking area

\begin{tabular}{|c|c|c|c|c|c|c|c|c|c|c|}
\hline \multicolumn{4}{|c|}{ Simulation: August 15th } & \multicolumn{4}{|c|}{ Simulation: December 21th } \\
\hline $\mathrm{h}$ & $\begin{array}{c}\mathrm{Ta} \\
{ }^{\circ} \mathrm{C}\end{array}$ & $\begin{array}{c}\text { Tmrt } \\
\mathrm{K}\end{array}$ & $\begin{array}{c}\mathrm{RH} \\
\%\end{array}$ & $\begin{array}{c}\mathrm{W} \\
\mathrm{m} / \mathrm{s}\end{array}$ & $\begin{array}{c}\text { UTCI } \\
\mathbf{}^{\circ} \mathrm{C}\end{array}$ & $\begin{array}{c}\text { Ta } \\
{ }^{\circ} \mathrm{C}\end{array}$ & $\begin{array}{c}\text { Tmrt } \\
\mathrm{K}\end{array}$ & $\begin{array}{c}\mathrm{RH} \\
\%\end{array}$ & $\begin{array}{c}\mathrm{W} \\
\mathrm{m} / \mathrm{s}\end{array}$ & $\begin{array}{c}\mathbf{U T C I} \\
\mathbf{0} \mathbf{C}\end{array}$ \\
\hline 0 & 21,18 & 288,27 & 86 & 1,4 & $\mathbf{2 0 , 4}$ & $-2,47$ & 265 & 100 & 1,22 & $\mathbf{- 5 , 7}$ \\
\hline 3 & 20,48 & 286,95 & 86 & 1,15 & $\mathbf{1 9 , 6}$ & -3 & 264 & 100 & 1,21 & $\mathbf{- 6 , 2}$ \\
\hline 6 & 19,78 & 286,27 & 86 & 1,13 & $\mathbf{1 9 , 1}$ & $-3,37$ & 264 & 100 & 1,2 & $\mathbf{- 7}$ \\
\hline 9 & 21,39 & 333,62 & 80 & 0,88 & $\mathbf{3 3 , 6}$ & 2,02 & 269,7 & 80 & 1,14 & $\mathbf{- 4 , 8}$ \\
\hline 12 & 29,35 & 340,7 & 62 & 0,96 & $\mathbf{4 0 , 1}$ & 1 & 276 & 89 & 1,18 & $\mathbf{1 , 3}$ \\
\hline 15 & 30,85 & 343,27 & 59, & 1,13 & $\mathbf{4 1 , 7}$ & 1,78 & 275,7 & 96 & 1,2 & $\mathbf{1 , 8}$ \\
\hline 18 & 28,1 & 336,36 & 68 & 1,25 & $\mathbf{3 8 , 2}$ & $-0,27$ & 267,03 & 100 & 1,1 & $\mathbf{- 2 , 6}$ \\
\hline 21 & 23,6 & 290,38 & 77 & 1,2 & $\mathbf{2 2 , 9}$ & $-1,54$ & 265,7 & 100 & 1,22 & $\mathbf{- 4 , 4}$ \\
\hline
\end{tabular}


Fontarrón: parking area

\begin{tabular}{|c|c|c|c|c|c|c|c|c|c|c|}
\hline \multicolumn{6}{|c|}{ Simulation: August 15th } & \multicolumn{5}{|c|}{ Simulation: December 21th } \\
\hline h & $\begin{array}{l}\text { Ta } \\
{ }^{\circ} \mathrm{C}\end{array}$ & $\begin{array}{l}\text { Tmrt } \\
\mathrm{K}\end{array}$ & $\begin{array}{l}\text { RH } \\
\%\end{array}$ & $\begin{array}{l}\mathrm{W} \\
\mathrm{m} / \mathrm{s}\end{array}$ & $\begin{array}{l}\text { UTCI } \\
{ }^{\circ} \mathrm{C}\end{array}$ & $\begin{array}{l}\mathrm{Ta} \\
{ }^{\circ} \mathrm{C}\end{array}$ & $\begin{array}{l}\text { Tmrt } \\
\mathrm{K}\end{array}$ & $\begin{array}{l}\mathrm{RH} \\
\%\end{array}$ & $\begin{array}{l}\mathrm{W} \\
\mathrm{m} / \mathrm{s}\end{array}$ & $\begin{array}{l}\text { UTCI } \\
{ }^{\circ} \mathrm{C}\end{array}$ \\
\hline 0 & 23,52 & 288 & 66 & 0,54 & 22 & $-3,31$ & 264,8 & 100 & 0,7 & $-3,3$ \\
\hline 3 & 22,29 & 287,12 & 70 & 1,3 & 20,5 & $-3,59$ & 264,24 & 100 & 0,7 & $-3,6$ \\
\hline 6 & 21,91 & 295,62 & 66 & 0,5 & 22,9 & $-4,01$ & 263,7 & 100 & 0,74 & $-4,1$ \\
\hline 9 & 23,15 & 337,99 & 59 & 0,7 & 34,9 & 0,99 & 272,67 & 80 & 0,79 & 0,6 \\
\hline 12 & 26,42 & 345,77 & 61 & 0,6 & 39,2 & 0,66 & 324,88 & $\begin{array}{c}90, \\
9\end{array}$ & 0,74 & 20,8 \\
\hline 15 & 27,6 & 348,1 & 61 & 0,6 & 40,0 & 0,32 & 275,4 & 99 & 0,73 & 2 \\
\hline 18 & 26,8 & 325,42 & 62 & 0,65 & 34,5 & $-1,3$ & 266,88 & 100 & 0,74 & $-1,9$ \\
\hline 21 & 24,51 & 290,51 & 64 & 0,5 & 23,4 & $-1,3$ & 265,65 & 100 & 0,73 & $-2,2$ \\
\hline
\end{tabular}

Horcajo: road

\begin{tabular}{|c|c|c|c|c|c|c|c|c|c|c|}
\hline \multicolumn{4}{|c|}{ Simulation: August 15th } & \multicolumn{4}{|c|}{ Simulation: December 21th } \\
\hline $\mathrm{h}$ & $\begin{array}{c}\mathrm{Ta} \\
{ }^{\circ} \mathrm{C}\end{array}$ & $\begin{array}{c}\mathrm{Tm} \mathrm{K} \\
\mathrm{K}\end{array}$ & $\begin{array}{c}\mathrm{RH} \\
\%\end{array}$ & $\begin{array}{c}\mathrm{W} \\
\mathrm{m} / \mathrm{s}\end{array}$ & $\begin{array}{c}\text { UTCI } \\
\mathbf{}^{\mathbf{C}}\end{array}$ & $\begin{array}{c}\text { Ta } \\
{ }^{\circ} \mathrm{C}\end{array}$ & $\begin{array}{c}\text { Tmrt } \\
\mathrm{K}\end{array}$ & $\begin{array}{c}\mathrm{RH} \\
\%\end{array}$ & $\begin{array}{c}\mathrm{W} \\
\mathrm{m} / \mathrm{s}\end{array}$ & $\begin{array}{c}\mathbf{U T C I} \\
\mathbf{0} \mathbf{C}\end{array}$ \\
\hline 0 & 24,4 & 290 & 97 & 2,02 & $\mathbf{2 4 , 5}$ & 1,32 & 266,61 & 100 & 1,9 & $\mathbf{- 4 , 2}$ \\
\hline 3 & 22,79 & 288,76 & 98 & 1,99 & $\mathbf{2 2 , 3}$ & 0,9 & 266,2 & 100 & 2 & $\mathbf{- 5}$ \\
\hline 6 & 21,5 & 287,7 & 98 & 1,95 & $\mathbf{2 0 , 6}$ & 0,6 & 265,9 & 100 & 2,04 & $\mathbf{- 5 , 4}$ \\
\hline 9 & 28,73 & 297,26 & 97 & 1,64 & $\mathbf{3 3}$ & 5,18 & 277,87 & 84 & 1,86 & $\mathbf{2 , 9}$ \\
\hline 12 & 34,3 & 343,2 & 84 & 1,68 & $\mathbf{4 9 , 4}$ & 4,6 & 274,6 & 99 & 1,9 & $\mathbf{3 , 4}$ \\
\hline 15 & 35,4 & 335,65 & 84 & 1,8 & $\mathbf{5 0 , 3}$ & 3,95 & 282,6 & 100 & 1,95 & $\mathbf{5 , 8}$ \\
\hline 18 & 32,22 & 299,65 & 93 & 1,9 & $\mathbf{2 7 , 9}$ & 2,31 & 267,73 & 100 & 1,96 & $\mathbf{- 3 , 3}$ \\
\hline 21 & 27 & 292 & 96 & 2,02 & $\mathbf{2 8 , 5}$ & 1,7 & 267,08 & 100 & 1,98 & $\mathbf{- 1}$ \\
\hline
\end{tabular}

Figure 19. Climate data and evaluation of UTCI thermal comfort index for the 3 case studies calculated in summer and winter conditions.

Source: Compiled by author using ENVImet and UTCIa002.exe. 
As seen in these tabulated values, discomfort conditions occur more often in summer than in winter:

- In summer discomfort conditions for heat stress occur from 9 a.m. to 9 p.m., corresponding to the part of the day that citizens use public space. In the remaining hours thermal comfort status has achieved, showing that there is a very sudden change of a condition from no thermal stress to strong heat stress in a very short time lapse.

- In winter, thermal perception is mostly equal to moderate cold stress in the night hours and slight cold stress during the day, reached the status of comfort in Fontarrón at 12 a.m.

Considering that the time of major occupation of outdoor space, goes from 9 am to 9 $\mathrm{pm}$, the simulations indicate that the most unfavourable conditions for the enjoyment of public space occur in summer and especially at 3 p.m. Furthermore, taking into account the mortality related to outdoor thermal condition, suggests that the mortality excess due to heat occurs without any lag time, whilst cold related mortality have a lag of some days (Hoppe 2002; Jendritzky, de Dear, and Havenith 2011) the study of comfort has been limited to the most unfavourable condition of heat stress occurring on August 15 at 3 p.m.

\subsection{Results of scenarios simulation}

The research methodology is established to define the guidelines for environmental design of urban spaces and is based on critical analysis of climatic behaviour of project scenarios. The climate parameters have been obtained with the support of thermal simulation tools Envi-met. During the scenario proposals project the following elements have been taken into account:

- The capability and sensitivity of simulation tool to models the urban space.

- The characteristics of the case studies according to the analysis of indicators.

- The microclimatic condition specially in relation to comfort conditions.

- The formal and structural degradation of urban space that justifies the need for the neighbourhood renovation.

Also, various scenarios resulting from the application of some of the project proposals put forward by the previous work, have been foreshadowed (Higueras et all. 2010). A series of simulations of different scenarios, designed to reform urban space without change the morphology of the buildings, have been conducted. Different models have been made by changing one parameter in each simulation in order to study the influence of each variable, regarding the climate values and, the users comfort. The simulations have been limited to study the summer conditions since they are the worst comfort conditions.

The strategies can be divided into two different approaches: a) modification of urban green spaces b) modification of surface materials. 
With regard to the green spaces, different scenarios are performed with different amount of green areas and with the use of different species. In terms of materials, solutions that allow greater permeability of the soils and the use of cool pavements are tested, through the introduction of new solutions in the soil database. Finally, the results of each simulation have been compared with the current state. The study of different solutions is shown in the analysis schedules. Each case study was analysed by areas, showing the result obtained from the application of the different strategies on three urban spaces:

- The parking area, because the land reserved for parking at ground level represents a significant proportion of public space.

- The canyons between buildings are usually considered as the remaining space in the urban design, despite the fact that the thermal processes in this volume of air has a decisive effect on the urban microclimate and energy consumption of buildings.

- The pedestrian squares, because it is the space of citizen coexistence, where it is more important to ensure comfort conditions in order to promote social relationship.

The information of scenarios comparison is organized in schedules that show the current status and then the results of different project scenarios. The current status schedule (the layout view is presented in the figure 20) shows a detailed description of specific portion of case study. There also contain: in 4.a satellite image of the area under study and the result of climatic simulation in top plan view (4.b) and vertical section view (4.c). The physic and climate current status is described in a 2 columns table (4.d): in the first one climate data and comfort status; in the second one general explanation of area. The general observation of climate performance obtained by simulation result has been detailed in the 4.e text box.

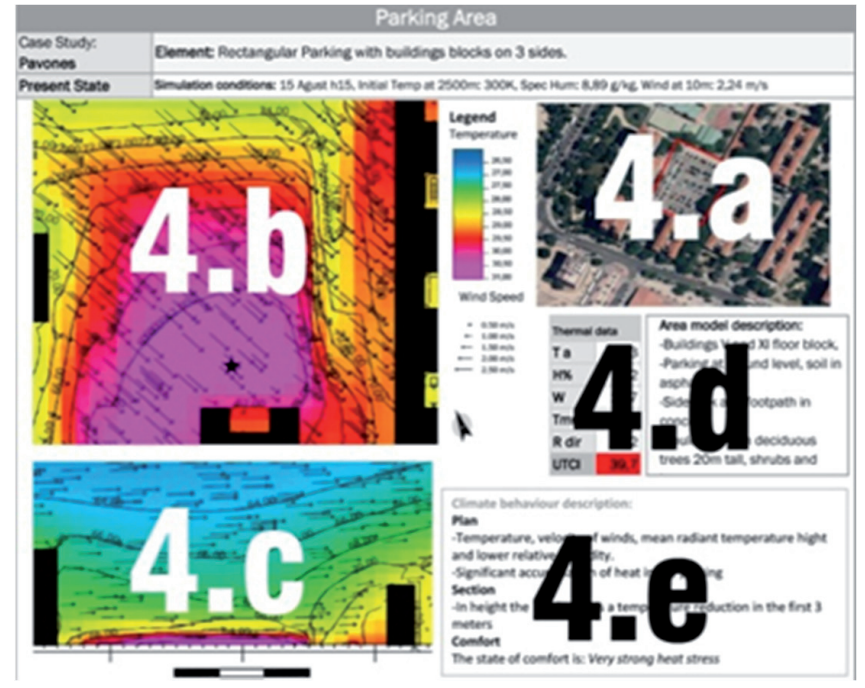

Figure 20. Current status schedules layout.

Source: Elaborated with ENVImet 3.1 and Microsoft Excel by the author. 
At the top of the next schedule there is a description of hypothetical project scenario. Then some maps show the simulation result indicated as follows: plan (5.a) and section (5.b) view where the temperature, wind speed and relative humidity isolines. The Thermal data table shows the atmosphere temperature $\left(\mathrm{Ta},{ }^{\circ} \mathrm{C}\right)$, relative humidity $(H, \%)$, Wind speed $(W, m / s)$, mean radiant temperature $\left(T m r t,{ }^{\circ} C\right)$, direct radiation $(R$ dir, $W / m)$ and UTCI index $\left({ }^{\circ} \mathrm{C}\right.$ equivalent) calculated in the same point (indicated in the Current State map with $\mathbf{m}$ ). In the Observation table there is a short explanation of the simulation result, especially comparing it with the current state

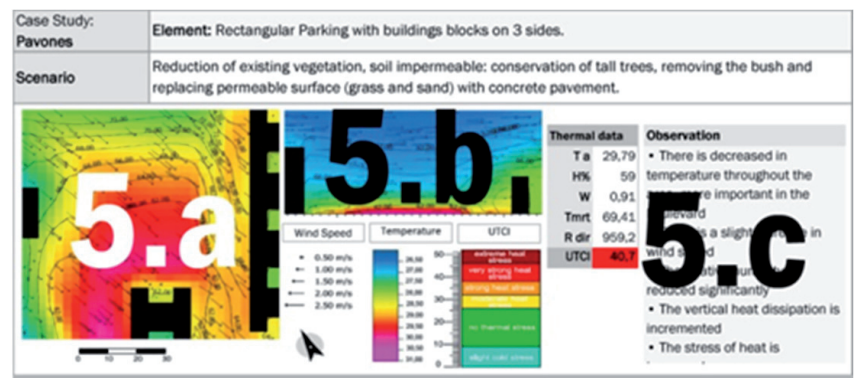

Figure 21. Scenario schedules layout.

Source: Elaborated with ENVImet 3.1 and Microsoft Excel by the author.

\subsection{Discussion of Scenarios Simulation Result}

The design of these proposed solutions are based on two points: a) the amount of vegetation, and $b$ ) the modification of surface materials. Considering the differences between the results obtained from each case study simulation, the general conclusions drawn from the observation of results are described below. Then the analysis of design scenarios, based on the comparative study of the current sate thermal comfort conditions with the project scenario, is described. The evaluation is realized using the comfort index UTCI and the thermal stress characteristic values scale. The assessment of strategies is the result of the difference between the UTCI current state and the UTCI scenario, expressed graphically as follows:

\begin{tabular}{lccccccc} 
SUTCI & -6 & -4 & -2 & $-1 \leq 0 \leq 1$ & 2 & 4 & 6 \\
\hline & 0 & 0 & 0 & 0 & 0 & 0
\end{tabular}

Regarding the choice of materials, the first solution proposed takes into account with the increase of impervious surfaces at the expense of natural surfaces and the reduction of vegetation. In general, it is observed: i) the decrease in temperature of about $1{ }^{\circ} \mathrm{C}$, ii) a relative humidity decreased due to reduction of pervious surfaces, and consequently the evaporation, iii) the wind changes differently depending on each case. It should be highlighted that the most important result is the reduction of the heat dissipation height. In all cases, a reduction of temperature in vertical section occurs, probably due to ventilation. The comfort conditions do not show an improvement in open spaces, such as car parks and squares, unlike the canyons where the thermal sensation improves. 


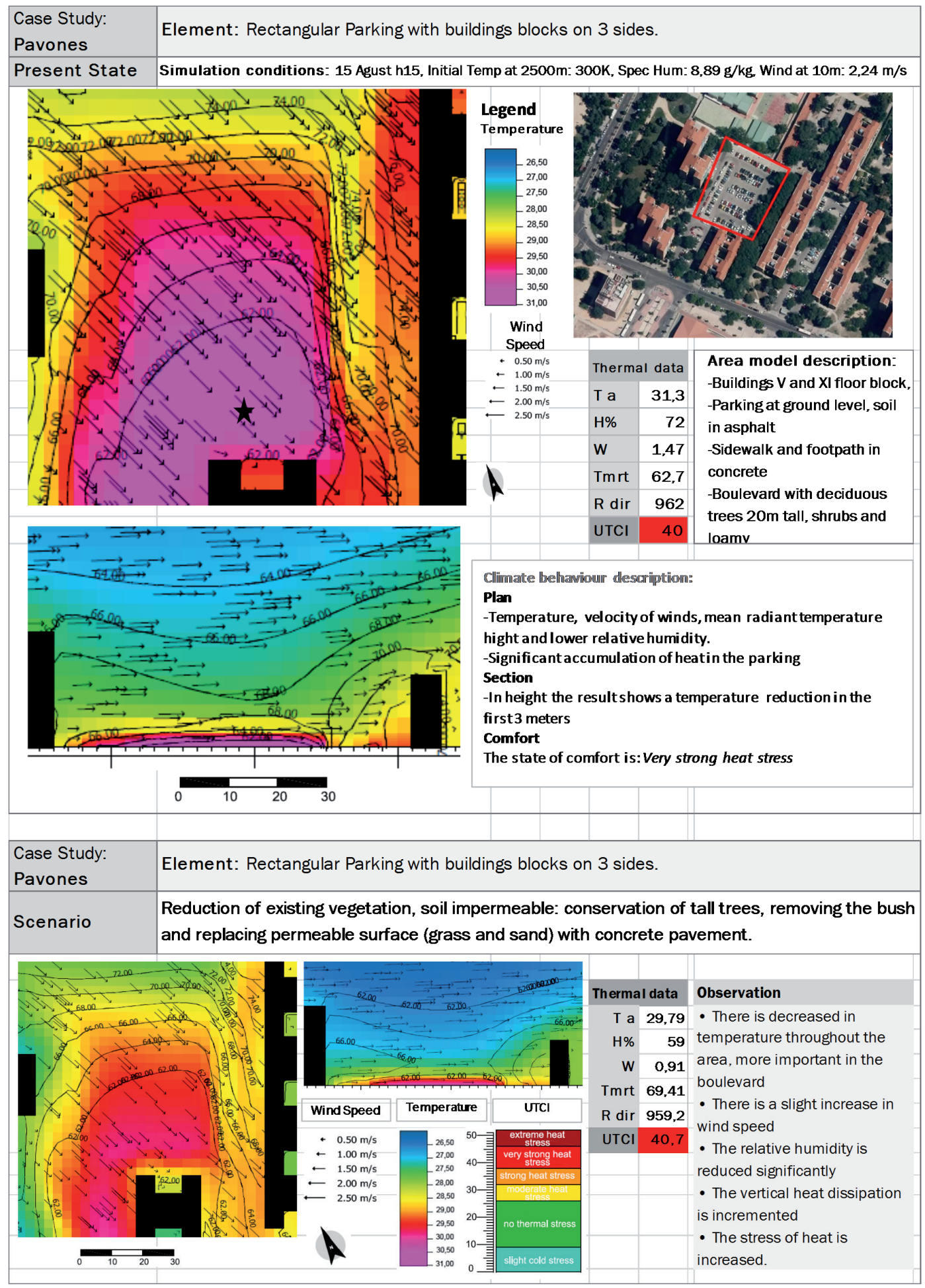

Figure 22. Parking in Pavones case study. Comparison between current state and "Reduction of existing vegetation, use of impervious soil" scenario hypotesis.

Souce: Compiled by Author 


\begin{tabular}{|c|c|c|c|}
\hline & Current State UTCI & Scenario UTCI & Comparison \\
\hline $\begin{array}{l}\text { Rectangular Parking with } \\
\text { buildings block on } 3 \text { sides. }\end{array}$ & 40 & 40,7 & ○ \\
\hline $\begin{array}{l}\text { Rectangular parking with } \\
\text { buildings block on } 2 \text { sides. }\end{array}$ & 40,3 & 39,3 & 0 \\
\hline $\begin{array}{l}\text { Rectangular parking with } \\
\text { buildings block on } 1 \text { side. }\end{array}$ & 40,5 & 39,3 & - \\
\hline $\begin{array}{l}\text { Canyon, buildings block } \\
\text { typology, N-S oriented, } \\
H / W=0,43\end{array}$ & 42 & 41,8 & ○ \\
\hline $\begin{array}{l}\text { Canyon, buildings block } \\
\text { typology, W-E oriented, } \\
\mathrm{H} / \mathrm{W}=1\end{array}$ & 37,7 & 38,2 & ○ \\
\hline $\begin{array}{l}\text { Canyon, buildings block } \\
\text { typology, N-S oriented, } \\
\mathrm{H} / \mathrm{W}=1,1\end{array}$ & 37,5 & 29,5 & 00 \\
\hline $\begin{array}{l}\text { Canyon, closed block building } \\
\text { typology, W-E oriented, } \\
H / W=0,6\end{array}$ & 33,9 & 30,9 & $\circ$ \\
\hline $\begin{array}{l}\text { Rectangular square with } \\
\text { trees, an EW orientation, } \\
\text { building on } 3 \text { sides }\end{array}$ & 40,1 & 39 & - \\
\hline $\begin{array}{l}\text { Rectangular square with } \\
\text { trees, an NS orientation, } \\
\text { building on } 4 \text { sides }\end{array}$ & 37,3 & 39,3 & 0 \\
\hline $\begin{array}{l}\text { Rectangular Square, } \\
\text { orientation NW-SE, closed } \\
\text { block building on } 2 \text { sides }\end{array}$ & 43,8 & 44,4 & ○ \\
\hline
\end{tabular}

Figure 23. Comparative assessment of thermal comfort feeling obtained by green space reduction application in different case studies. Elaborated with ENVImet 3.1, UTCI_a002.exe and Microsoft Excel.

Source: Compiled by Author.

New materials, called cool materials, have been introduced in the software database in order to check the result produced for its application in the urban environment. The materials used are: eco-block pavement for pedestrian areas and parking, white asphalt (Synnefa et al. 2011, Santamouris et al. 2011, Santamouris et al. 2012) and high reflective asphalt: PerfectCool ${ }^{8}$ (Wan et al. 2009) for the roads. As shown in experimental research on these materials (Santamouris et al. 2012, Santamouris et al. 2011, Karlessi et al. 2009, Synnefa et al. 2011), the system shows that a reduction

8 PerfectCool is the pavement coating developed by the Public Works Research Institute, Nippo Corporation Co, Miracool Co. Ltd, Kanematsu Corporation Co., and the Tokyo Institute of Technology. The material is based on principle that increasing the reflectance of the pavement surfaces, less heat will be absorbed, thereby lowering daytime temperature of the pavements. PerfectCool consist of dark, low reflective color pigments mixed with high infra-red heat reflective pigments and fine hollow ceramic particles to reduce thermal conduction and heating of the paint (Wan et al. 2009). 
of temperature, and higher values have been obtained for the application of white asphalt. It results in the decrease of temperature in both horizontal and vertical section: the homogenization of microclimate conditions by reducing the gradient in the study area can be appreciated. Despite all, the value of UTCI increases, which indicates that citizen comfort gets worse. This is the result of the increased value of Tmrt obtained by ENVI-met simulation process. More thoroughly studies of the result have been attempted. The instructions provided in the software guide and literature has been consulted, but it has not been possible to obtain the extensive description of calculation procedure. The confirmation of the value of Tmrt estimated is open to future developments.

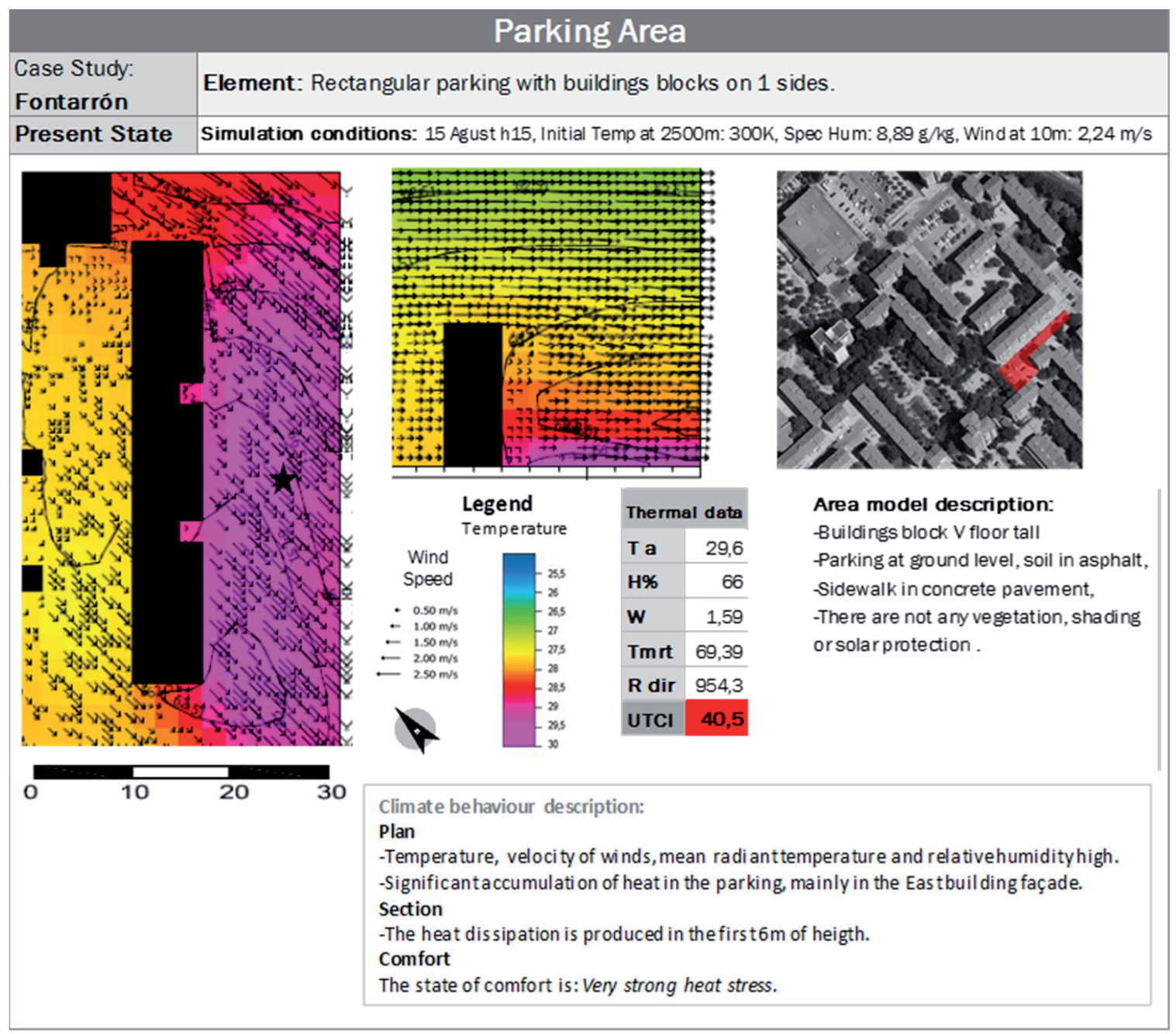

Figure 24. Parking area in Fontarrón case study I. Comparison between current state and use of cool materials scenario hypotesis.

Source: Compiled by Author. 


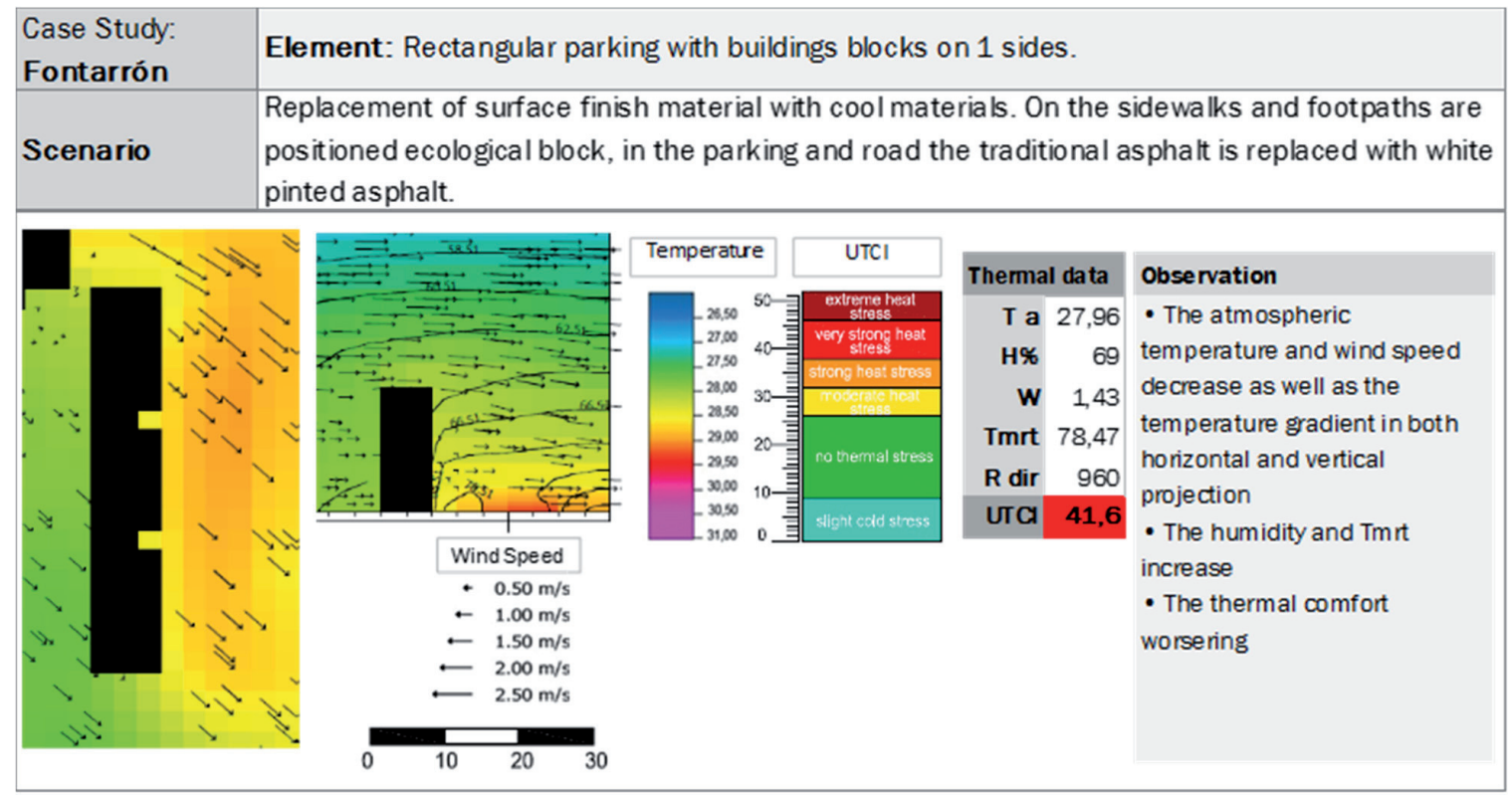

Figure 25. Parking area in Fontarrón case study II. Comparison between current state and use of cool materials scenario hypotesis.

Source: Compiled by Author.

\begin{tabular}{|c|c|c|c|}
\hline & Current State & Scenario & Comparison \\
\hline $\begin{array}{l}\text { Rectangular parking with } \\
\text { buildings block on } 2 \text { sides. }\end{array}$ & 40,3 & 40,9 & 0 \\
\hline $\begin{array}{l}\text { Rectangular parking with } \\
\text { building blocks on } 1 \text { side. }\end{array}$ & 40,5 & 41,6 & 0 \\
\hline $\begin{array}{l}\text { Canyon, building block } \\
\text { typology, } \\
\text { W-E oriented, } \\
\mathrm{H} / \mathrm{W}=1\end{array}$ & 37,7 & 36,7 & 0 \\
\hline $\begin{array}{l}\text { Canyon, building block } \\
\text { typology, } \\
\mathrm{N}-\mathrm{S} \text { oriented, } \\
\mathrm{H} / \mathrm{W}=1,1\end{array}$ & 37,5 & 36,8 & 0 \\
\hline $\begin{array}{l}\text { Rectangular square with trees, } \\
\text { building on } 3 \text { sides }\end{array}$ & 40,1 & 36,3 & 0 \\
\hline $\begin{array}{l}\text { Rectangular square with trees, } \\
\text { building on } 4 \text { sides }\end{array}$ & 37,3 & 37,2 & 0 \\
\hline
\end{tabular}

Figure 26. Comparative assessment of thermal comfort feeling obtained by replacing the existing soil with cool materials reduction applied in different case studies.

Source: Elaborated by the author with ENVImet 3.1, UTCI_a002.exe and Microsoft Excel. 


\begin{tabular}{|c|c|c|c|}
\hline \multicolumn{4}{|c|}{$\begin{array}{l}\text { Scenario: Replacement of material surface finishing with Perfect Cool and } \\
\text { ecological block }\end{array}$} \\
\hline & Current State & Scenario & Comparison \\
\hline $\begin{array}{l}\text { Rectangular Parking with } \\
\text { buildings block on } 3 \text { sides. }\end{array}$ & 40 & 42,5 & - \\
\hline $\begin{array}{l}\text { Canyon, building block } \\
\text { typology, } \\
\text { W-E oriented, } \\
\text { H/W }=1\end{array}$ & 37,7 & 33 & 0 \\
\hline $\begin{array}{l}\text { Rectangular Square, closed } \\
\text { block building in } 2 \text { sides }\end{array}$ & 43,8 & 43,2 & - \\
\hline
\end{tabular}

Figure 27. Comparative assessment of thermal comfort feeling obtained by replacing the existing soil with cool materials reduction applied in different case studies.

Source: Elaborated by the author with ENVImet 3.1, UTCI_a002.exe and Microsoft Excel.

A simulation has been performed by using water as a material, with the purpose of checking the operation of software, because the use of a deep water tank is not an applicable solution to the regeneration of urban space. The output result is a decrease of temperature, the Tmrt, and the improvement of comfort.

To evaluate the effect of vegetation use in urban spaces, different scenarios have been chosen:

- A reduction of existing vegetation, leaving only the tallest trees.

- An increase of vegetation through the use of grass in the ground of pedestrian areas and parking.

- A use of shrubs or tall trees.

The reduction of vegetation produces worsening comfort conditions. Only in two cases the result is an improvement of comfort due to the reduction of the Tmrt and relative humidity. As indicated above, this result should be subject of further studies.

The opposite result is obtained by increasing the amount of vegetation and green areas, since it originates a general decrease of temperature, a relative humidity increase and reduction of the UTCI value. Depending on the area and the solution, different results have been obtained. The use of grass reduces the temperature and increases relative humidity, but the effect on comfort is not very relevant. The introduction of shrubs, 1.5 meters tall, does not show significant changes from the initial state. The use of tall trees shows an amelioration of urban microclimate. The output of calculation shows that increasing the amount of trees up to $30 \%$ of the surface, causes a reduction of: temperature, and winds speed; on the other hand relative humidity is increased. Above all, the reduction of direct sunlight is meaningful for heat stress amelioration. 


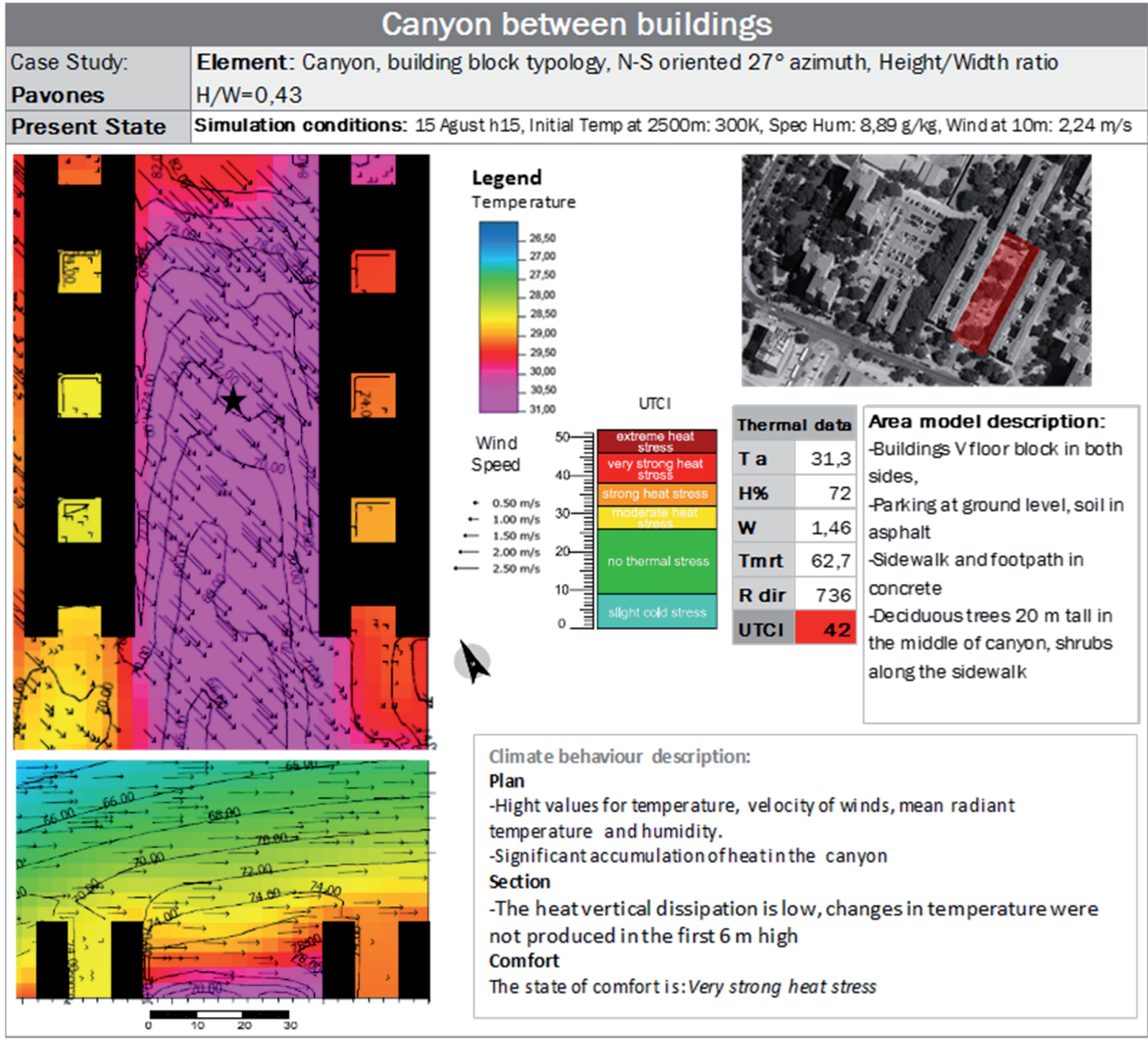

\begin{tabular}{|l|l|}
\hline $\begin{array}{l}\text { Case Study: } \\
\text { Pavones }\end{array}$ & $\begin{array}{l}\text { Element: Canyon, building block typology, N-S oriented } 27^{\circ} \text { azimuth, Height/Width ratio } \\
\mathrm{H} / \mathrm{W}=0,43\end{array}$ \\
\hline Scenario & In the pedestrian areas replacement of impermeable surfaces with grass. Roadways in asphalt. \\
\hline
\end{tabular}

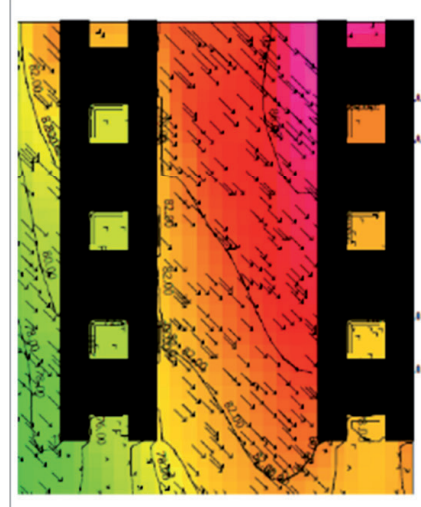

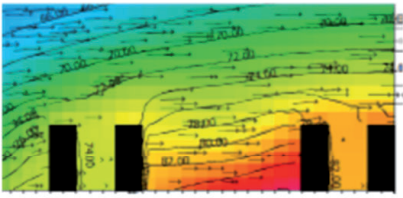

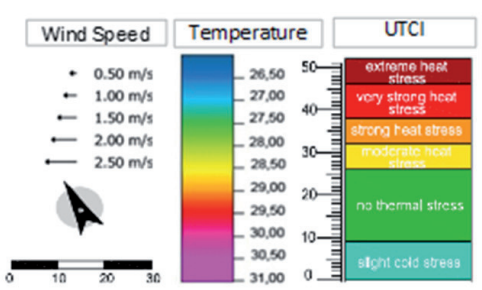

\begin{tabular}{|c|c|c|}
\hline \multicolumn{2}{|c|}{ Thermal data } & \multirow{2}{*}{$\begin{array}{l}\text { Observation } \\
\text { - Sensitive temperature }\end{array}$} \\
\hline T a & 29,45 & \\
\hline H\% & 85 & \multirow{5}{*}{$\begin{array}{l}\text { decrease particularly in the } \\
\text { side NE } \\
\text { - Significant increase in } \\
\text { relative humidity } \\
\text { - The wind speed decreases }\end{array}$} \\
\hline $\mathbf{w}$ & 0,98 & \\
\hline Tmrt & 54,28 & \\
\hline & 7384 & \\
\hline UTCI & 391 & \\
\hline & & $\begin{array}{l}\text { as you move into the canyon } \\
\text { - There is high heat dissipatio }\end{array}$ \\
\hline
\end{tabular}




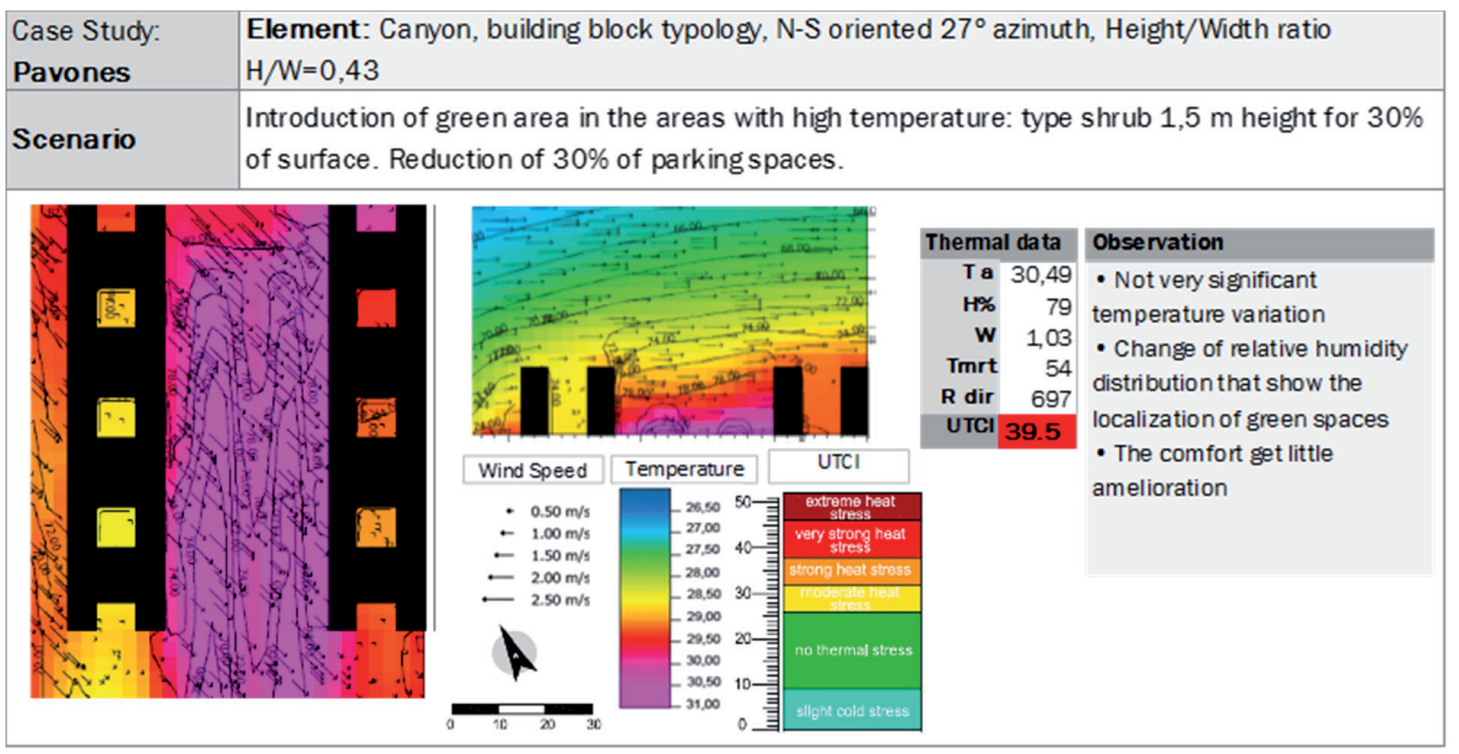

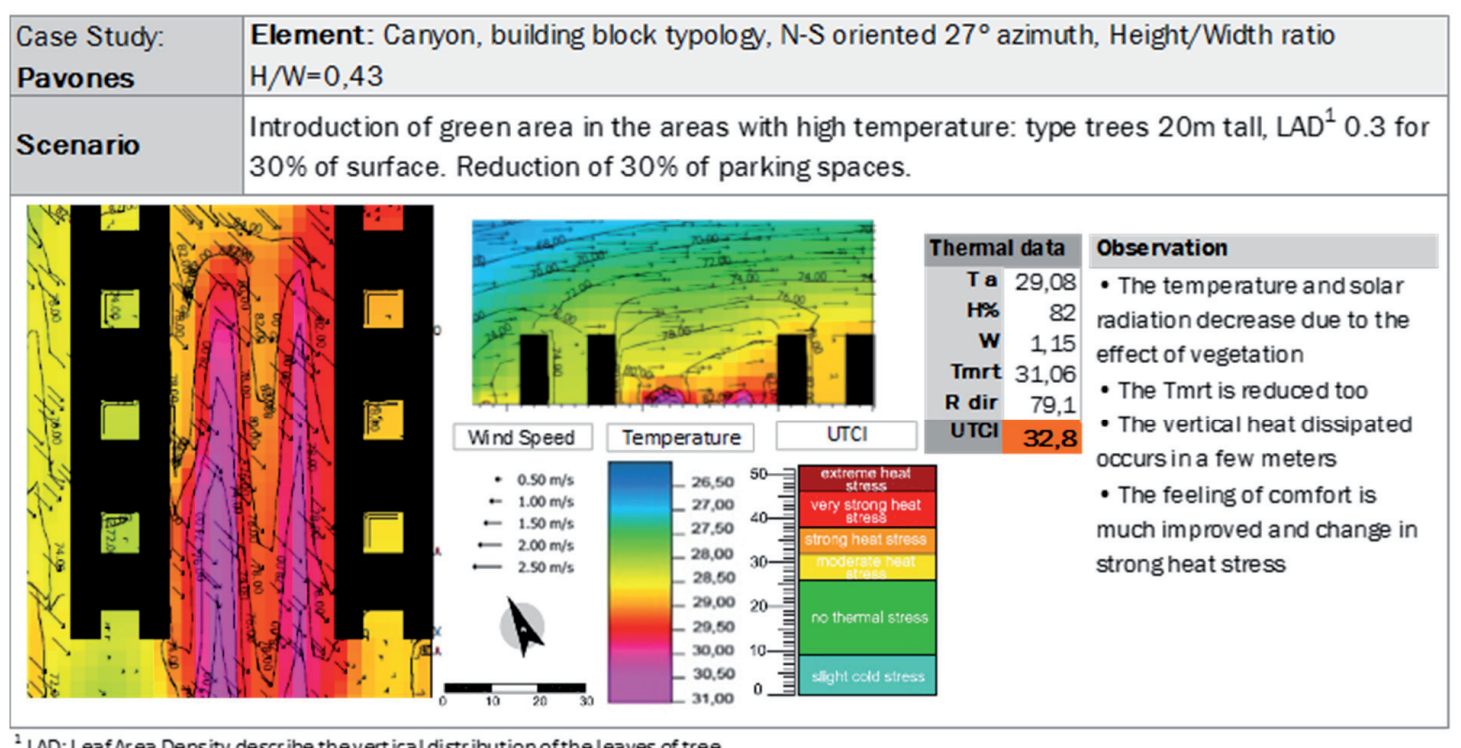

${ }^{1}$ LAD: Leaf Ar ea Density descr ibe thevert ical distr ibution of the leaves of tree

Figures 28 and 29. Canyon in Pavones case study. Comparison between current state and three different hypothesis of scenarios where there is a green area increase.

Source: Compiled by Author. 


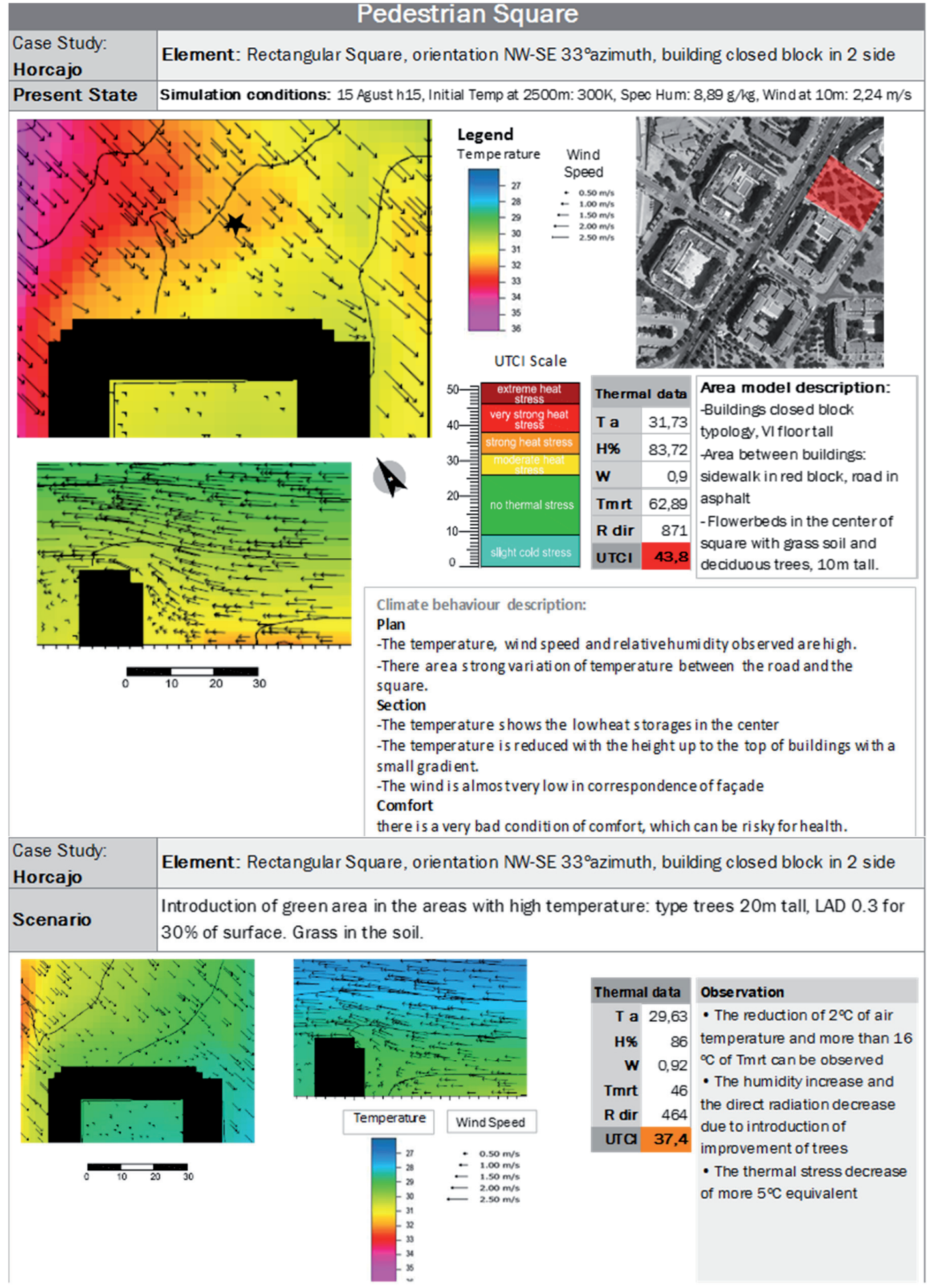

Figure 30. Square area in Horcajo case study. Comparison between the current state and the scenario with the green areas increase.

Source: Compiled by Author. 


\begin{tabular}{|c|c|c|c|}
\hline \multicolumn{4}{|c|}{$\begin{array}{l}\text { Scenario: Introduction of } 1,5 \mathrm{~m} \text { height shrub for } 30 \% \text { of surface. } \\
\text { Reduction of } 30 \% \text { of parking spaces. }\end{array}$} \\
\hline UTCI $\left({ }^{\circ} \mathrm{C}\right):$ & Current State & Scenario & Comparison \\
\hline $\begin{array}{l}\text { Rectangular Parking with } \\
\text { buildings block on } 3 \text { sides. }\end{array}$ & 40 & 41,9 & ○ \\
\hline $\begin{array}{l}\text { Rectangular parking with } \\
\text { buildings block on } 2 \text { sides. }\end{array}$ & 40,3 & 39,2 & O \\
\hline $\begin{array}{l}\text { Rectangular parking with building } \\
\text { blocks on } 1 \text { side. }\end{array}$ & 40,5 & 37,4 & ○ \\
\hline $\begin{array}{l}\text { Canyon, building block typology, } \\
\mathrm{N}-\mathrm{S} \text { oriented, } \mathrm{H} / \mathrm{W}=0,43\end{array}$ & 42 & 39,5 & ○ \\
\hline $\begin{array}{l}\text { Canyon, building block typology, } \\
W-E \text { oriented, } H / W=1\end{array}$ & 37,7 & 36,7 & ○ \\
\hline $\begin{array}{l}\text { Canyon, building block typology, } \\
\mathrm{N}-\mathrm{S} \text { oriented, } \mathrm{H} / \mathrm{W}=1,1\end{array}$ & 37,5 & 36,8 & - \\
\hline $\begin{array}{l}\text { Canyon, closed block building } \\
\text { typology, } \mathrm{W}-\mathrm{E} \text { oriented, } \mathrm{H} / \mathrm{W}=0,6\end{array}$ & 33,9 & 33,7 & ○ \\
\hline
\end{tabular}

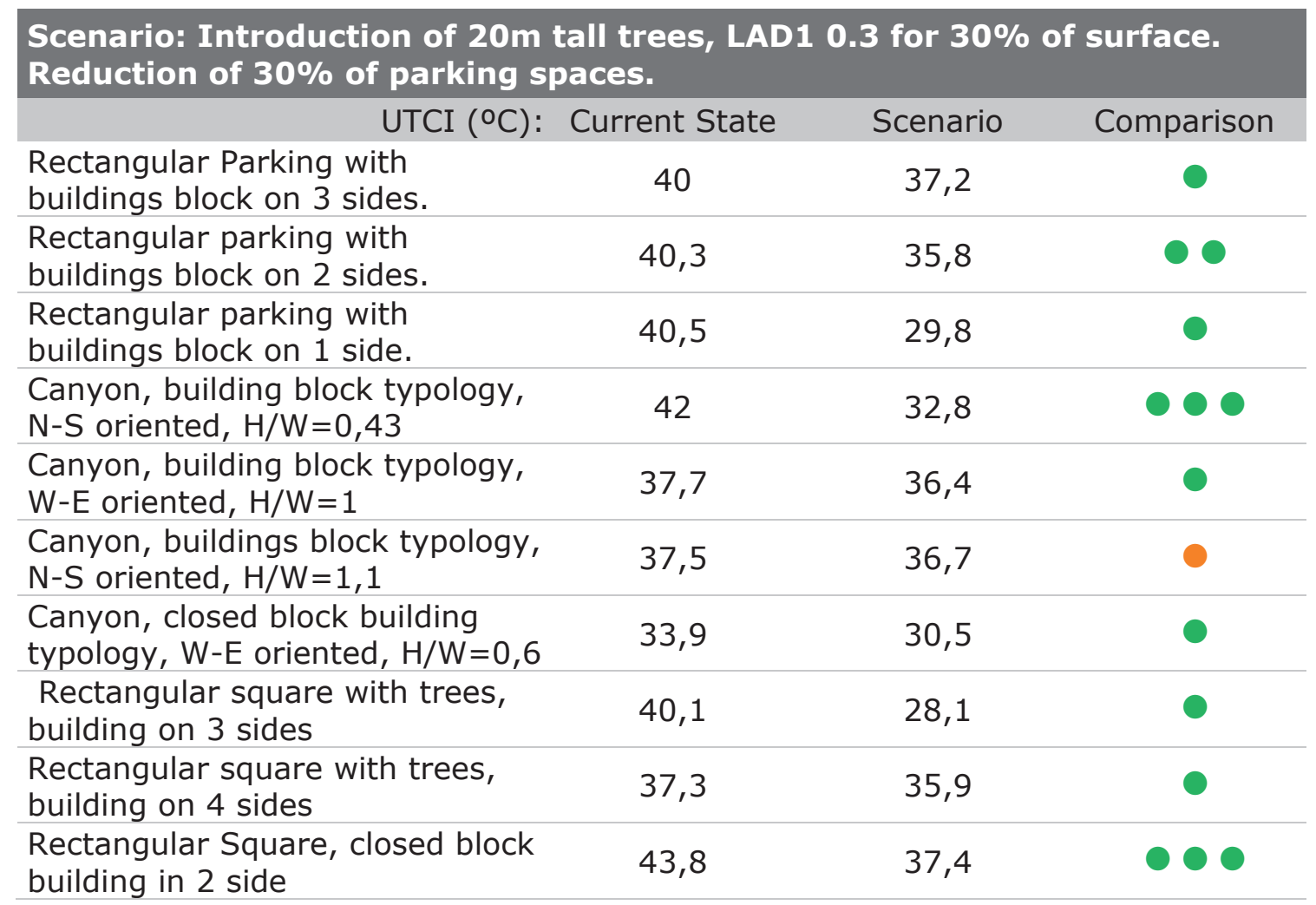

Figures 31 and 32. Comparative assessment of thermal comfort obtained by the increase of green areas in different cases study. It is elaborated with ENVImet 3.1, UTCI_a002.exe and Microsoft Excel. Source: Elaborated by the author with ENVImet 3.1, UTCI_a002.exe and Microsoft Excel. 
The comparative study of scenarios project has allowed the creation of a summary table, the abacus, where the evaluation parameter is the comfort index UTCI. The aim of this summary table is to provide a support tool, easy to be used for the designer in the urban spaces refurbishment projects towards greater environmental quality. The designer can choose among the options evaluated, which allows the greatest benefit in terms of the user comfort.

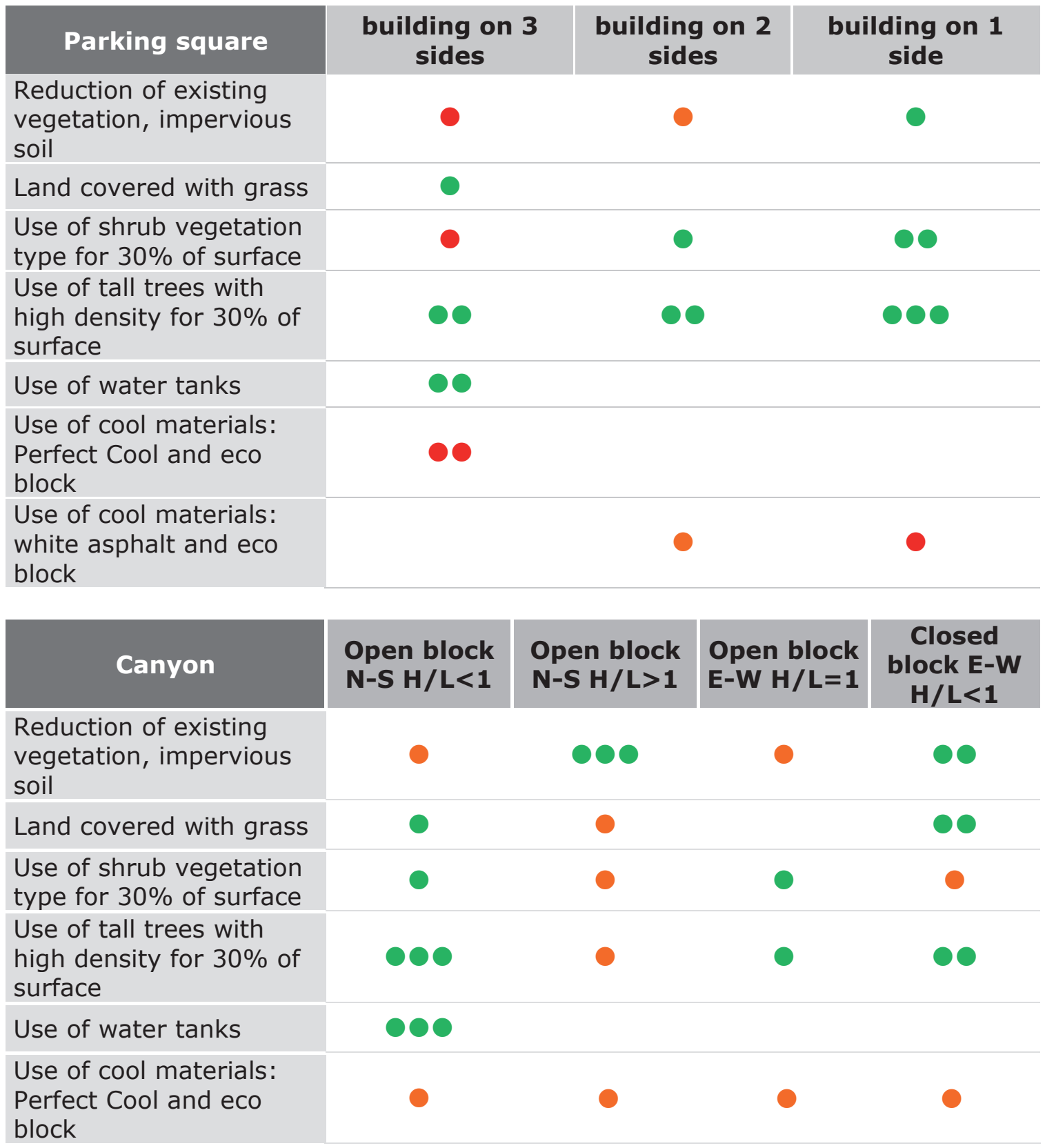




\begin{tabular}{|c|c|c|c|c|}
\hline & quare & $\begin{array}{c}\text { E-W } \\
\text { Orientation } \\
\text { building in } 3 \\
\text { sides }\end{array}$ & $\begin{array}{c}\mathrm{N}-\mathrm{S} \\
\text { Orientation } \\
\text { building in } 4 \\
\text { sides }\end{array}$ & $\begin{array}{c}\text { E-W } \\
\text { Orientation } \\
\text { building in } 1 \\
\text { side }\end{array}$ \\
\hline $\begin{array}{l}\text { Reducti } \\
\text { vegetat } \\
\text { soil }\end{array}$ & $\begin{array}{l}\text { of existing } \\
\text { impervious }\end{array}$ & 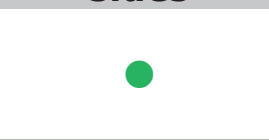 & - & - \\
\hline $\begin{array}{l}\text { Use of } \\
\text { high de } \\
\text { surface }\end{array}$ & $\begin{array}{l}\text { trees with } \\
y \text { for } 30 \% \text { of }\end{array}$ & 000 & 0 & 000 \\
\hline $\begin{array}{l}\text { Use of } \\
\text { Perfect } \\
\text { block }\end{array}$ & $\begin{array}{l}\text { materials: } \\
\text { l and eco }\end{array}$ & 0 & 0 & 0 \\
\hline \multirow{2}{*}{$\triangle \mathrm{UTCl}$} & -6 & -2 & $\leq 1$ & 6 \\
\hline & 00 & 0 & 0 & 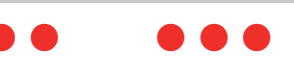 \\
\hline
\end{tabular}

Figures 33 to 36 . Summary table where the evaluation parameter is the comfort index UTCI. Source: Elaborated by the author.

The results may differ from each other, because the comfort depends on climatic parameters interaction: temperature, wind, humidity and mean radiant temperature. The countermeasure produces a different result on comfort for each urban zone. For instance, reduction of vegetation produces worsening the initial condition to the exclusion of canyon with $\mathrm{H} / \mathrm{W}<1$ in closed block buildings, or the use of shrub in the same case produce an amelioration, in others, no change in the parking with building in its 3 sides, causes the worsening of comfort. Despite this, the usual performance can be related to the use of green areas. In all cases, the use of tall trees produces an improvement of thermal sensation. Therefore, we can conclude that the use of green areas in urban space is a countermeasure efficient and applicable to different urban typology. 


\section{CONCLUSION}

The initial objective of the doctoral thesis was to define guidelines for the regeneration of public space taking into account the improvement of user thermal comfort. In order to achieve this goal, an analytical approach has been established. The comparative analysis of different design scenarios, allowed the evaluation of several constructive solutions applied to urban context of the $20^{\text {th }}$ Century city. The research offers a new methodological approach to the bioclimatic design of urban space, introducing a character of greater objectivity in the definition of project strategies.

The verification of the initial hypotheses has guided the research development. The study of micro-level urban space, using analytical calculation approach, shows that outdoor thermal performance, hence the well-being perception of users, can be modified throughout the renovation project. This can be achieved changing two elements: vegetation and finishing materials; without changing morphology or buildings orientation, different microclimatic conditions can be obtained.

\section{Indicators for the space and climatic analysis}

The first specific aim would define a system of indicators to characterize urban space, considering that six numerical indicators have been selected from the literature review, it should be pointed out that it is worth mentioning Rueda's sustainability indicators (Rueda 2006). The limited number of indicators, associated with a target of acceptability, has allowed the easy characterization and diagnosis of the study areas. However, during the course of the work, the need of an additional indicator on the urban structure has emerged. In addition to the H/W ratio, a qualitative indicator about type of urban morphology should be added.

The definition of microclimatic characterization parameters has been a key element, without which urban spaces analysis and evaluation of scenarios would have not been realized. From the beginning, it was decided to seek an index capable of representing the state of well-being by the environmental conditions.

Throughout a review of the literature regarding the topic and the assessment work of a case study in Madrid with different parameters, the UTCI index has been selected as the indicator for this research. The index responds to diverse requirements:

- It is a numerical value.

- It links the environmental conditions with physiological response of the human body.

- It considers the adaptive component.

- It is suitable for its implementation in Madrid.

- It defines a temperature equivalent and comfort standard allowing a wide range of evaluation. 
The use of the index is appropriate in the study of Madrid microclimate. UTCI is so versatile and easy to obtain that can be usefully applied for future studies on thermal comfort in open spaces. Moreover, the definition of a numerical evaluation scale allows the comparative analysis of similar scenarios, which is not possible for example, with graphic systems such as bioclimatic maps (Givoni 1998, Olgyay 1969, Ashrae 2005).

\section{Evaluation of the simulation tool}

The analytical calculation has been realized throughout the use of simulation software. The first observation that can be extracted from the study regards limitations in the use of calculation software. Amongst consulted tools, it was found that ENVImet 3.1 meets the following compromise between: 3D model complexity, output type and runtime. However, during use, many bugs and limitations have been revealed as indicated below:

1. No similarity between results and typical climate values of Madrid. Simulation results are not close to the mean values: maximum and minimum temperature or daily seasonal distribution, wind speed and radiation. Although, the most outstanding feature value is relative humidity; since it reaches its double value and it even triples the monthly average values collected in Madrid. The change in the starting values with the measured data by the Meteorological Station have not been enough to solve this problem.

2. Besides the selection of the climate system, there are other design limitations that compromise the simulation model:

- Lack of flexibility in the buildings morphology definition, surface materials and internal temperature.

- Incapability in simulating sunshades systems or/and the effect of evaporative cooling effect due to microclimate or fountains.

- Inability to account anthropogenic inputs such as traffic or heating.

- Little sensitivity to small changes in urban space such as replacement of paving.

- Uncertainty of the accuracy of the software calculation, especially in relation to the radioactive component and the Tmrt calculation.

Mistakes made on the simulation calculus performed by the tool, were detected during the research work so that it limits its applicability. However, the methodology can be considered valid for:

a) Its application to summer

b) A comparative analysis of different scenarios. 
The methodology of the 3D model numerical simulation and a comparison of different project scenarios can be considered a valid support in the decision-making phase for the following reasons:

1) Less expenditure of time compared to other systems.

2) Less economic investment, due to the software is an open source and does not require powerful hardware.

3) Friendly use, the involvement of highly specialized personnel is not required.

This study should be limited to the comparative analysis between scenarios rather than absolute values. However, the numerical analysis highlights some salient observations that may be of practical application in real projects.

\section{Urban morphology}

At first, simulations show that urban morphology of courtyard buildings have more unfavourable microclimatic performance rather than open block building typology, especially in summer conditions due to: higher values of temperature, unfavourable conditions in both horizontal and vertical views, as well a higher differential between zones. Open block building typology allows more capability and flexibility on intervention in outdoor space, consequently increases the capacity to incorporate measures to improve environmental quality.

As a result of the study, it is possible to conclude that urban rationalist morphology in buildings blocks and wide public green spaces, is the most commonly used in Madrid suburban built-up areas until early 1980s, which can be successfully regenerated. The large amount of space between buildings allows a free in design, thanks to which, it is possible to implement several strategies to improve thermal comfort conditions. In general, it can be observed that making a few changes, such as pavement replacement and path redesign, it is possible to improve readability and quality of open space with little investment.

\section{Recommendations for land use in renovation works}

The research work carried out, was limited to the study of two types of urban morphology:

i) building blocks

ii) courtyard buildings

And the variation of two parameters:

a) vegetation

b) finishing materials. 
The exploration series are not wide enough to define the guidelines for different situations that can take place in an urban refurbishment. Even so, it is possible to make some general considerations which may be used as a guideline for designers.

The replacement of surfaces with high reflectance materials is a solution that must be applied thoughtfully. In fact, if on one side the increase of the material albedo allows obtaining lower temperature on surface and air, on the other side causes the increase of the reflected radiation. From the point of view of summer energy consumption, the environmental temperature reduction is definitely a good achievement. But as regards the user thermal comfort sensation, this solution does not produce positive results. From the simulations made, the application of cool materials does not show an improvement of the comfort feeling, or even, it can be counterproductive.

The results regarding the change of soil are not trustworthy, but there is no doubt that the increase of green spaces, especially with the introduction of tall trees improved microclimatic conditions, thus the comfort of people.

The simulations results show that the increase of green areas in open space has a positive impact on microclimatic conditions. Among the various options, it is always better to opt for the use of tall trees with high leaf density, rather than grass or shrubs.

The scenario that proposes: reduction of parking spaces at ground level, replacement of paved areas with high reflectance materials or permeable surfaces combined with a significant increase in the presence of green areas (more than $30 \%$ of the surface) is the solution that best meets the needs of thermal comfort. It is also worth to emphasize the beneficial effect of the vegetation presence in urban space in terms of air and environment quality.

Although not listed among the starting objectives, another conclusion that can be obtained from this work is that the outdoor space features, such as the amount and type of vegetation and materials used, influences microclimatic conditions, energy buildings consumption and people comfort. Environmental quality maintenance and energy conservation in our cities should be among the main objectives of the Government, who should reflect them in their actions. In suburbs, unoccupied space, sometimes superabundant, has created degraded and low quality areas (instituto Juan Herrera UPM 2010).

But the privatization proposal tout-court can further damage environmental quality, in addition to depriving citizens of their space. To avoid these problems, the assignment of public space to the private agents should be complemented by legislation. It should aim to preserve and/or improve thermal and environmental quality. For instance, the transfer could be provided for free with the condition of: maintaining or increasing the amount of green areas and pervious surfaces, prohibiting tall trees cut down, and employing cool materials to replace existing soil, etc. 


\section{Design Guide Line}

Regarding to the definition of strategies for environmental design of urban spaces refurbishment, the work achieve a first approximation for the realization of tool that could be supportive in the early stages of decisions making phase, to guide the project towards the improvement of the thermal conditions and comfort.

Nowadays, the existent tools and guides present important limitations: at the first they have been thought for new construction projects, so their application in renovation is very limited. Regarding countermeasures for the outdoor space, in some cases does not set a clear reference to the climatic characteristics of the place, nor to typological features of built space.

Finally some certification systems and design guides, put on the same level the use of green areas and the employment of low emissivity materials such as coolmaterials. This is without taking into account the various effects produced after taking the measure related above, especially regarding the user comfort.

Environmental certification systems, such as LEED (credit SS 7.1) gives the same score to different strategies such as the use of shading systems o high reflection pavements, without taking into account that each measure generates totally different processes. Even the Italian system certification ITACA, assigns the same weight $(20 \%)$ to "use of green areas" or "use of high reflective surfaces", without considering the combined effect of shading and evapotranspiration provided by the vegetation.

Although is not set into the starting objective, other result is the definition of objective methodology for heat island countermeasure evaluation. The assessment is based on quantitative calculation obtained by simulation process in different context conditions.

The abacus, based on parametric study results, gives an indication about the effectiveness of different countermeasures, friendly and easy to use also for nonexperts. This research is a first approach for the development of a tool that could be supportive of urban refurbishment works, to guide decision making from earlier stages towards thermal performance and comfort improvement. To realize a complete abacus that could be an effective support, the evaluation of a wide number of case studies and project scenarios should be carried out. Due to remaining doubts about the trustworthy of the software and the singularity of each urban space, the abacus must be used just as a rough guide. The final evaluation should always be made case by case.

The conflict between the need to consider as many parameters as possible and the reduction of variables involved, in order to simplify the calculation, has not been solved yet. However, the availability of computer systems has allowed breakthroughin the energy simulation, and the ability to perform complex models. Nowadays, there are a lot of tools capable to support and guide the design process, but is the designer who must choose between them the most appropriate, case by case and phase by phase. The meet point between the accuracy of model and the difficulty of preparatory process should be decided according to specific needs. In this work we have tried to 
propose tools that do not require highly professional skilled or expensive equipment. The systems employed, although a specific training may be required, they could be used by technicians or administrative bodies with a reasonable expenditure of time.

It is proper mentioned that research methodology throughout the analysis of case studies has not the purpose to formulate universal laws regarding the observed data. It is a phenomena exploration among the possibilities offered by modern tools, which can be used to introduce new research hypothesis and to guide design decisionmaking and policy in urban areas.

The practical application of this research is made for the decision making process. After site characterization, definition of critical points and targets, the planner must choose between applicable measures those that will improve the quality of space. The more researches related to thermal performance of urban space are made, the deeper knowledge in the processes that regulate microclimate conditions will be multiplied. As more researches related to thermal performance of urban spaces multiply and have deep knowledge in the processes that regulate microclimate conditions. So that strategic guidelines and policy interventions to regulate the space and safeguard the thermal comfort of their users might be made. Thus, as already exists for buildings, specific regulations for bioclimatic urban areas renovation must be made in order to improve the city sustainability and quality of the citizen's life. 


\section{RECOMMENDATIONS FOR FURTHER WORK}

Despite numerous studies on the determination of microclimatic conditions of the urban space have been conducted during several decades, these researches are usually focused on the definition of guidelines for the design of new urban developments. In some cases, it is possible to find references for the analysis of the traditional city, coming to the diagnosis at the most, but without looking for the possible solutions for the outdoor space. Concerning urban regeneration, it exists broad referential knowledge on historic buildings renovation, architectural modern heritage and city centre segment. Nevertheless, in relation to the regeneration of suburban areas the state of the art is very poor and scarce.

The theme of the thesis, the climatic amelioration of the $20^{\text {th }}$ century city, is a topic of great interest, especially in relation to the needs to promote urban sustainability. Besides, the thesis could be a reference in the research background which is absolutely lacking in this aspect. The current energy and economic crisis, forces us to rethink the city model, which has to be more sustainable, efficient, and preservative of natural resources, considering the territory as the main source of life. The change towards this new model cannot be achieved regardless of the regeneration of the deprived, inefficient and out of standard neighbourhoods.

The opening of a new research line in this field is needed to fulfil the referential gap and be supportive not only to researchers, but also to designers, public agents and stakeholders. Certainly another line of research should be dedicated to the improvement of the calculation model. Focused on this direction, recommendations for future actions in research developments are:

1. Allow reviewing and modification of default climate used by the software. That could also allow the introduction of data from local measurement weather stations and urban climate maps.

2. In the new ENVI-met 4 version some of the limitations of 3D models have been solved allowing the more elaborated models realization.

3. Provide users the complete calculation equations used for the tool. If this information was accessible, expert users can check the operation of software and have a feedback with developers.

The methodology should be applied to many case studies, with different climatic conditions and city morphology, aiming to test it and improve the reliability of the results and its applicability. This could create an assortment of varied casuistry, enough to extend the strategies abacus, including the main urban typologies used in Spain. The abacus may provide, from initial project stages, strategic guidelines for improving the thermal environment quality of urban public space. 


\section{BIBLIOGRAPHY}

AKBARI, H; POMERANTZ, M. \& TAHA, H. (2001). "Cool Surfaces and Shade Trees to Reduce Energy use and Improve Air Quality in Urban Areas", Solar Energy, vol. 70, no. 3, pp. 295310.

ALI-TOUDERT, F; \& MAYER, H. (2006). "Numerical Study on the Effects of Aspect Ratio and Orientation of an Urban Street Canyon on Outdoor Thermal Comfort in Hot and Dry Climate", Building and Environment, 2, vol. 41, no. 2, pp. 94-108.

ANDREU, A. R. (2009). La crisis del neoliberalismo1.

ASHRAE. (2005). ASHRAE Handbook. Fundamentals. Atlanta:

BORJA, J.\& MUXI, Z. (2000). El Espacio Público: Ciudad Y Ciudadanía. Barcelona: Xarxa de Municipis - Electa.

BRÖDE, P. et al. (2012a). "Deriving the Operational Procedure for the Universal Thermal Climate Index (UTCI)", International Journal of Biometeorology, vol. 56, no. 3, pp. 481-494.

BRÖDE, P. et al. (2012b). "Predicting Urban Outdoor Thermal Comfort by the Universal Thermal Climate Index UTCI-a Case Study in Southern Brazil", International Journal of Biometeorology, vol. 56, no. 3, pp. 471-480.

BRUQUETAS CALLEJO, M., et al. (2005). "La Regeneración De Barrios Desfavorecidos", Documentos De Trabajo (Laboratorio De Alternativas), no. 67, pp. 1.

BRUSE, M. (2004). ENVI-Met Website. Online: http://www.envimet.com.

BRUSE, M. \& FLEER, H. (1998a). "Simulating Surface-plant-air Interactions Inside Urban Environments with a Three Dimensional Numerical Model", Environmental Modelling \& Software, vol. 13, no. 3, pp. 373-384.

BRUSE, M. \& SKINNER, C. J. (1999). Rooftop Greening and Local Climate: A Case Study in Melbourne.

BRUSE, M. \& FLEER, H. (1998). "Simulating Surface-plant-air Interactions Inside Urban Environments with a Three Dimensional Numerical Model", Environmental Modelling and Software, 10, vol. 13, no. 3-4, pp. 373-384.

CANDAS, V. (2005). To be Or Not to be Comfortable: Basis and Prediction, Volume 3, pp. 207215.

CÁRDENAS JIRON, L. (2012). "Caracterización de patrones bioclimáticos en tejidos urbanos residenciales", 82, Instituto Juan de Herrera, Departamento de Urbanística y Ordenación del Territorio, Escuela técnica Superior de Arquitectura de Madrid. Recurso on-line disponbile en: http://polired.upm.es/index.php/ciur/article/view/1840/1841 [Última consulta 30/08/2013].

CUCHÍ, A. \& SWEATMAN, P. (2011). Una visión-país para el sector de la edificación en españa. hoja de ruta para un nuevo sector de la vivienda. Barcelona: GBCe-CONAMA. 
D. STANNERS, P. (1995). Europe's Environment - the Dobrish Assessment. Copenhaguen: D. STANNERS \& P. Bourdeau ed.

DE LA CRUZ MERA, Á. (2010). La renovación urbana integral: una apuesta de futuro. Málaga (España).

DIMOUDI, A. \& NIKOLOPOULOU, M. (2003). "Vegetation in the Urban Environment: Microclimatic Analysis and Benefits", Energy and Buildings, vol. 35, no. 1, pp. 69-76.

FARIÑA TOJO, J. (2003a). "Ciudades Menos Insostenibles", Boletín CF S, no. 25.

FARIÑA TOJO, J. (2003b). "Sostenibilidad y racionalidad de los procesos de urbanización", Boletín CF S, no. 24.

FARIÑA TOJO, J. (2001). "Naturaleza urbana", Boletín CF S, no. 15.

FARIÑA TOJO, J. \& NAREDO, J. (2010). Libro Blanco de la sostenibilidad en el planeamiento urbanístico español. Madrid: Ministerio de Vivienda.

FIALA, D. et al. (2010). "UTCI-Fiala Multi-Node Model of Human Heat Transfer and Temperature Regulation", International Journal of Biometeorology, pp. 1-13.

FIORETTI, R. et al. (2010). "Green Roof Energy and Water Related Performance in the Mediterranean Climate", Building and Environment, 8, vol. 45, no. 8, pp. 1890-1904.

FLORENCIA RODRÍGUEZ, M. (2001). "La política de erradicación en el asentamiento Rodrigo Bueno Costanera Sur", Mundo Urbano, Diciembre 2001, vol. 34.

GAJA I DÍAZ, F. (2009). "Urbanismo sostenible, urbanismo estacionario. Ideas para la transición", Revista Digital Universitaria. DGSAC-UNAM, vol. 10.

GIRIDHARAN, R., et al. (2007). "Urban design factors influencing heat island intensity in highrise high-density environments of Hong Kong", Building and Environment, 10, vol. 42, no. 10, pp. 3669-3684.

GIVONI, B. (1998). Climate considerations in building and urban design. New York: Van Nostrand Reinhold.

GÓMEZ DE PEROZO, N. (2012). "Estrategias para el control microclimático del espacio entre edificaciones en clima cálido - húmedo", 91, Instituto Juan de Herrera, Departamento de Urbanística y Ordenación del Territorio, Escuela técnica Superior de Arquitectura de Madrid. Recurso on-line disponbile en: http://polired.upm.es/index.php/ciur/article/view/2394/2475 [Última consulta 30/08/2013].

HASSID, S., et al. (2000). "The effect of the Athens heat island on air conditioning load", Energy and Buildings, vol. 32, no. 2, pp. 131-141.

HAVENITH, G. et al. (2012). "The UTCI-Clothing Model", International Journal of Biometeorology, vol. 56, no. 3, pp. 461-470.

HIGUERAS, E. (2011). "Urbanismo bioclimático", Cuadernos De Investigación Urbanística, 24, Instituto Juan de Herrera, Departamento de Urbanística y Ordenación del Territorio, Escuela 
técnica Superior de Arquitectura de Madrid. Recurso on-line disponbile en: http://polired.upm.es/index.php/ciur/article/view/238/234 [Última consulta 30/08/2013]

IDEA (INSTITUTO PARA LA DIVERSIFICACIÓN Y AHORRO DE LA ENERGÍA). (2000). Guía del planeamiento urbanístico energéticamente eficiente. Madrid: IDEA

INSTITUTO JUAN HERRERA (ETSAM-UPM). (2010). Plan especial de mejora del medio ambiente urbano de los Polígonos $A$ y $C$ de Moratalaz. Documento de aprobación inicial. Madrid: Ayuntamiento de Madrid.

INTERGOUVERNAMENTAL PANEL ON CLIMATE CHANGE. (2013). IPCC Fourth Assessment Report: Climate Change 2007. Electronic resource available from: http://www.ipcc.ch/publications and_data/ar4/wg1/en/tssts-2-5.html.

JENDRITZKY, G; DE DEAR, R. \& HAVENITH, G. (2012). "UTCI-Why another Thermal Index?", International Journal of Biometeorology, pp. 1-8.

KÁNTOR, N; \& UNGER, J. (2011). "The most problematic variable in the course of humanbiometeorological comfort assessment-the mean radiant temperature", Central European Journal of Geosciences, vol. 3, no. 1, pp. 90-100.

KARLESSI, T. et al. (2009). "Development and testing of thermochromic coatings for buildings and urban structures", Solar Energy, 4, vol. 83, no. 4, pp. 538-551.

KNEZ, I. \& THORSSON, S. (2006). "Influences of culture and environmental attitude on thermal, emotional and perceptual evaluations of a public square", International Journal of Biometeorology, vol. 50, no. 5, pp. 258-268.

KNEZ, I., et al. (2009). "Psychological mechanisms in outdoor place and weather assessment: towards a conceptual model", International Journal of Biometeorology, vol. 53, no. 1, pp. 101111.

LAUNDER, B. \& SPALDING, D. (1974). "The numerical computation of turbulent flows", Computer methods in applied mechanics and engineering, 3, vol. 3, no. 2, pp. 269-289.

LEFEBVRE, Henri. (1973). La Rivoluzione Urbana. Roma: Armando.

LÓPEZ GÓMEZ, A., et al. (1991). El clima urbano: teledetección de la isla de calor en Madrid. Madrid: CSIC.

MARSH, A. (2010). Autodesk-Ecotect (Version 5.6).

MEYN, S. \& OKE, T. (2009). "Heat fluxes through roofs and their relevance to estimate of urban heat storage", Energy and Buildings, 7, vol. 41, no. 7, pp. 745-752.

MIRZAEI, P. \& HAGHIGHAT, F. (2010). "Approaches to study urban heat island - abilities and limitations", Building and Environment, 10, vol. 45, no. 10, pp. 2192-2201.

NAREDO, J. M. (2005). "Instrumentos financieros y económicos para la sostenibilidad urbana", Boletín CF S, no. 29/30.

NAREDO, J. M. (2003). "Instrumentos para paliar la insostenibilidad de los sistemas urbanos", Boletín CF S, no. 24. 
NIACHOU, A. et al. (2001). "Analysis of the green roof thermal properties and investigation of its energy performance", Energy and Buildings, 9, vol. 33, no. 7, pp. 719-729.

NIKOLOPOULOU, M. (2004). Designing open spaces in the urban environment: a bioclimatic approach. Athens: Centre for Renewable Energy Sources, EESD, FP5.

NIKOLOPOULOU, M. \& LYKOUDIS, S. (2007). "Use of outdoor spaces and microclimate in a mediterranean urban area", Building and Environment, vol. 42, no. 10, pp. 3691-3707.

NIKOLOPOULOU, M. \& LYKOUDIS, S. (2006). "Thermal comfort in outdoor urban spaces: analysis across different european countries", Building and Environment, vol. 41, no. 11, pp. 1455-1470.

OCHOA, J.M. (1999). La vegetación como instrumento para el control microclimático.

OKE, T. R. (1980). Thermal environment in urban areas. Stockhölm: Swedish Council for Building Research.

OKE, T. R. (1988). "Street design and urban canopy layer climate", Energy and Buildings, 3/22, vol. 11, no. 1-3, pp. 103-113.

OLGYAY, V. (1969). Desing with Climate. New Jersey: Princeton University Press (3rd ed). P

POLIDORI, P. (2006). I Quaderni della formazione ambientale. Milano: APAT

ROBINSON, D. (2011). Computer modelling for sustainable urban design: physical principles, methods and applications. London: Earthscan.

ROGERS, R.; and GUMUCHDJIAN, P. Ciudades Para Un Pequeño Planeta. GG, 2000.

RUEDA, Salvador. Plan Especial De Indicadores De Sostenibilidad Ambiental De La Actividad Urbanística De Sevilla. Gerencia de Urbanismo. Ayuntamiento de Sevilla ed. Barcelona: , 2006.

SAMAALI, Mehrez, et al. Analysis of a 3D Boundary Layer Model at Local Scale: Validation on Soybean Surface Radiative Measurements. Atmospheric Research, 2007, vol. 85, no. 2, pp. 183-198.

Sánchez de la Flor, Francisco; and ALVAREZ DOMINGUEZ, Servando. Modelling Microclimate in Urban Environments and Assessing its Influence on the Performance of Surrounding Buildings. Energy and Buildings, 2004, vol. 36, no. 5.

SANTAMOURIS, M., et al. Energy and Climate in the Urban Built Environment. . SANTAMOURIS, M. ed., Athens, Greece: University of Athens, 2001. ISBN 1-873936-90-7.

SANTAMOURIS, M., et al. Using Cool Paving Materials to Improve Microclimate of Urban areasDesign Realization and Results of the Flisvos Project. Building and Environment, 2012, vol. 53, pp. 128-136.

SANTAMOURIS, M.; SYNNEFA, A. and KARLESSI, T. Using Advanced Cool Materials in the Urban Built Environment to Mitigate Heat Islands and Improve Thermal Comfort Conditions. Solar Energy, 2011. 
SHASHUA-BAR, L.; and HOFFMAN, M. E. The Green CTTC Model for Predicting the Air Temperature in Small Urban Wooded Sites. Building and Environment, 2002, vol. 37, no. 12, pp. $1279-1288$.

SMITH, Claire; and LEVERMORE, Geoff. Designing Urban Spaces and Buildings to Improve Sustainability and Quality of Life in a Warmer World. Energy Policy, 12, 2008, vol. 36, no. 12, pp. 4558-4562. ISSN 0301-4215.

STEEMERS, Koen; and STEANE, Mary A. Environmental Diversity and Architecture. London: Spon Press, 2004. ISBN 0-415-31478-X.

SYNNEFA, A., et al. Experimental Testing of Cool Colored Thin Layer Asphalt and Estimation of its Potential to Improve the Urban Microclimate. Building and Environment, 2011, vol. 46, no. 1 , pp. $38-44$.

SYNNEFA, A.; SANTAMOURIS, M.and AKBARI, H. Estimating the Effect of using Cool Coatings on Energy Loads and Thermal Comfort in Residential Buildings in various Climatic Conditions. Energy and Buildings, 11, 2007, vol. 39, no. 11, pp. 1167-1174. ISSN 0378-7788.

TORRES PÉREZ, F. La Integración De Los Inmigrantes Y Algunos De Los Desafíos Que Nos Plantea. Talasa, 2002.

TUMINI, Irina. El Microclima Urbano En Los Espacios Abiertos. Estudio De Casos En Madrid. Madrid: ETSAM-UPM, 2013.

TURÉGANO ROMERO, José A. Arquitectura Bioclimática Y Urbanismo Sostenible. . Prensas Universitarias de Zaragoza ed., , 2009.

VALENZUELA RUBIO, M. Ciudades Y Sostenibilidad: El Mayor Reto Urbano Del Siglo XXI. Lurralde: Investigación Y Espacio, 2009, no. 32, pp. 405-436.

VOOGT, J. How Researchers Measure Urban Heat Islands, 2007.

WAN, W. C., et al. A Study on the Effectiveness of Heat Mitigating Pavement Coatings in Singapore. , 2009.

WONG, Eva. Reducing Urban Heat Islands: Compendium of Strategies. Climate Protection Partnership Division, 2007.

WONG, M. S., et al. A Simple Method for Designation of Urban Ventilation Corridors and its Application to Urban Heat Island Analysis. Building and Environment, 2010a, vol. 45, no. 8, pp. 1880-1889.

WONG, Nyuk Hien, et al. Thermal Evaluation of Vertical Greenery Systems for Building Walls. Building and Environment, 3, 2010b, vol. 45, no. 3, pp. 663-672. ISSN 0360-1323.

\section{Acknowledgements}

This research has been developed in the framework of the ECOURBAN project "Methodology for the energy and environmental impact assessment and the ecodesign of urban areas", co-funding by the Spanish Ministry for Science and Innovation (Spanish National Plan for Scientific Research, Development and Technological Innovation 2008-2011 - Ref. number ENE2010-19850). 


\section{ANNEX I}

\section{Schedule of case study analysis: PAVONES}

All of data showed have been obtained through simulation process with ENVImet 3.1 and ECOTECT

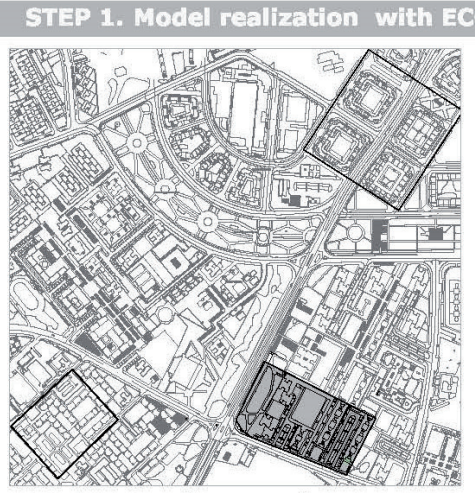

Localization of case study

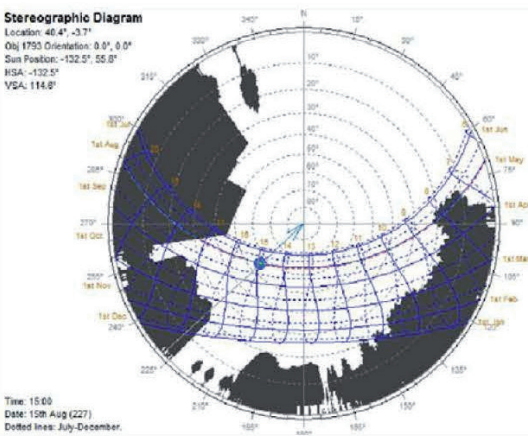

Skye View Factor Analysis

Observation point in the centre of parking area

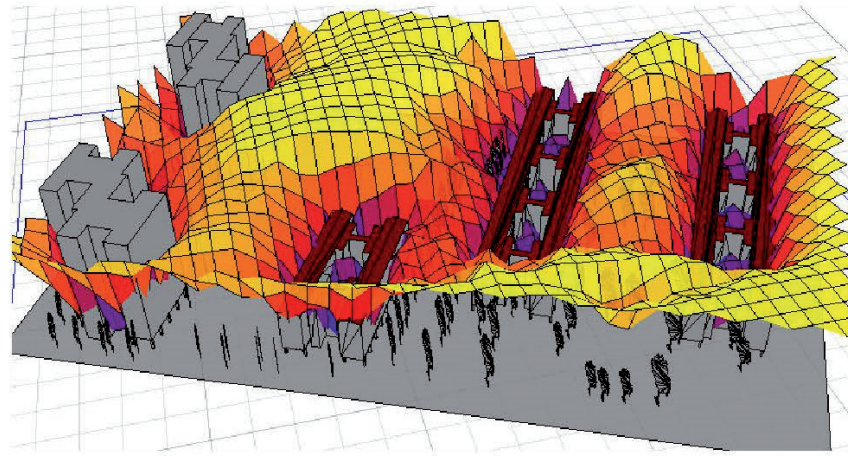

Solar direct radiation analysis.

Ammount and distribution of solar direct radiation for the 15th august al 15:00 h.

\section{Observation SVF analysis}

The study with ecotec is limited to analyze the component of the direct solar radiation in the summer condition, simulated on the 15th of August. The Stereographic diagram of SVF,

measured in the center of the parking, shows that the area is exposed to the sun for the most of the year. Emphasize that in the middle of the day (11 a.m.- 4 p.m.) the point is not shaded in any month of the year.
Observation solar radiation analysis Direct solar radiation is greater at the parking area. In the area of the boulevard the radiation incident amount on the buildings is reduced by shading effect due to trees. The shading effect also occurs in the canyon, but it is lower than in the boulevard. 


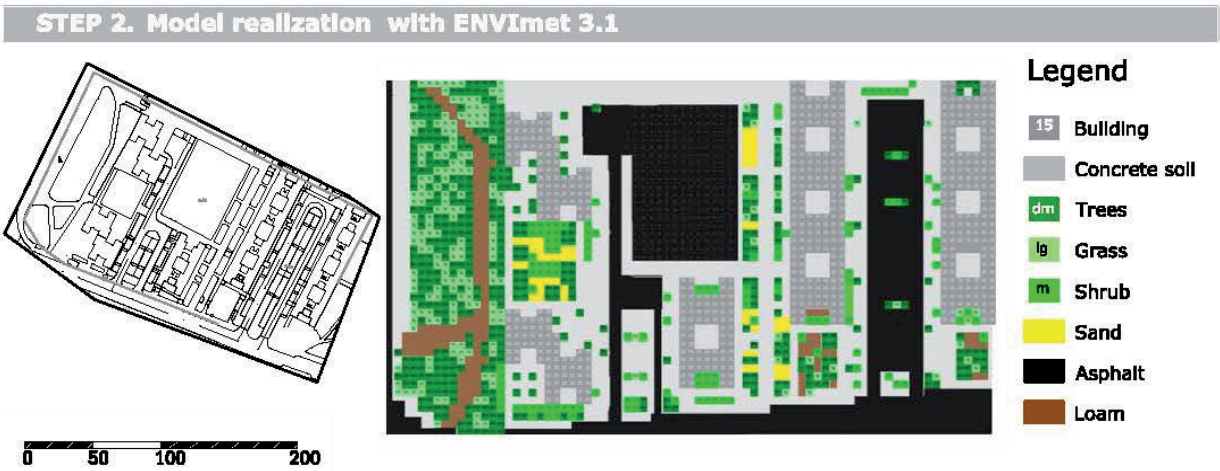

Orthophoto map

Schematic 3D simulation model. Plant View

\section{SIEP 3. ENVImat Simulation Reault - Day 15th august, time 1.5h}

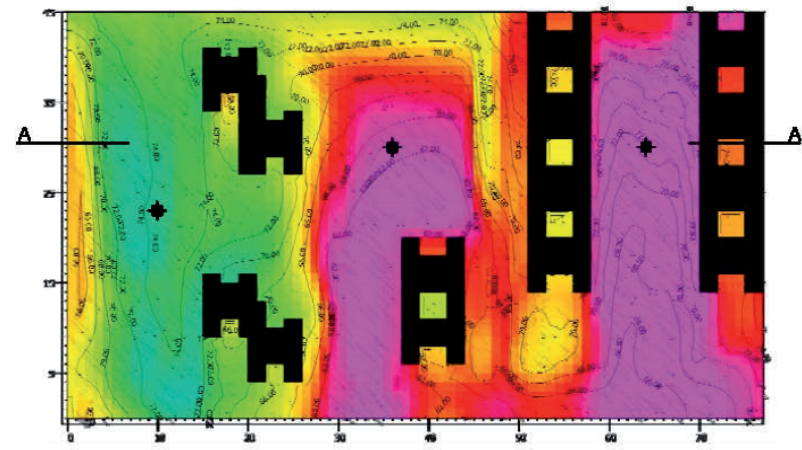

Plant View of total area. xy $1,20 \mathrm{~m}$ height

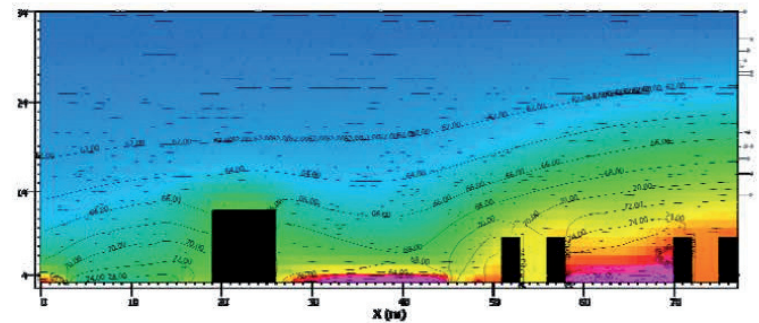

Section A-A view total area
Legend

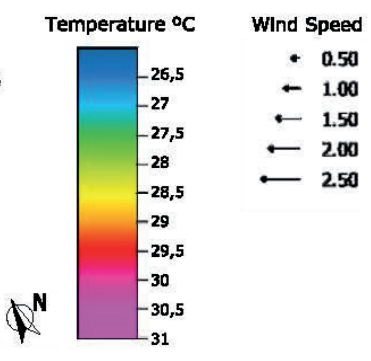

\section{DATA}

$\operatorname{Tmax} 31,60^{\circ} \mathrm{C} \quad \operatorname{Tm} \ln 27,20^{\circ} \mathrm{C}$ Wmax $1,7 \mathrm{~m} / \mathrm{s}$ Wmin $0,7 \mathrm{~m} / \mathrm{s}$ Hmax $75 \% \quad H$ mln $59 \%$ Tmrt max 70,29 Tmrt min 26,44 $\Delta T$ hortzontal $4,40^{\circ} \mathrm{C}$ $\Delta T$ vertical above of canopy layer $(33 \mathrm{~m})$ $5^{\circ} \mathrm{C}$

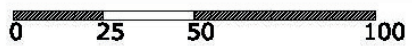

\section{General Observation of Simulation Result}

The simulation result shows no homogeneity in microclimatic conditions. Temperature, wind speed and relative humidity are strongly influenced by the location of buildings and land use:

-The difference between maximum and minimum temperature is above $4{ }^{\circ} \mathrm{C}$. The cold zone is localized at the parks,

while the hot zones are located in correspondence with the parking and the canyon between buildings in line.

-Above the 48 meters of altitude, corresponding to $2 \mathrm{H}$ height of the tallest building, the influence of the urban

-Above the 48 meters of altitude, corresponding to $2 \mathrm{H}$ height of the tallest building, the influence of the urban
environment in the microclimate Is inslgnificant. The canyon has a more pronounced influence than the Isolated bullding.

- From the helght of $2 \mathrm{H}$ temperature and relative humldity decreases proportlonally with helght whlle the winds speed did
. not change. 


\section{SIEP 4, ENVumet Simulation Result - Detalled review}
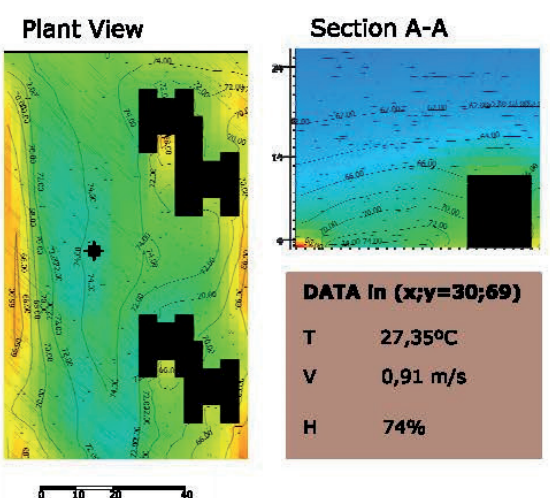

DATA in $(x ; y=30 ; 69)$

T $27,35^{\circ} \mathrm{C}$

V $0,91 \mathrm{~m} / \mathrm{s}$

H $\quad 74 \%$

\section{Green Area:}

green area with tall trees, declduous and coniferous soil with grass and natural terrain, paths in clay and gravel.

\section{Detailed Observation of Green Area}

The park area has mild temperatures more than the entire area. The wind speed is average and the relattve humldity is high. Observed conditlons are generally stable, with no abrupt changes. Even in vertically the air conditions are almost homogeneous. Only there is a slight increase in temperature closed to the building. The simulation shows the presence of the road in the east border, characterized by a higher bemperature and low humidity. In high heat dissipation is observed at low altitudes.

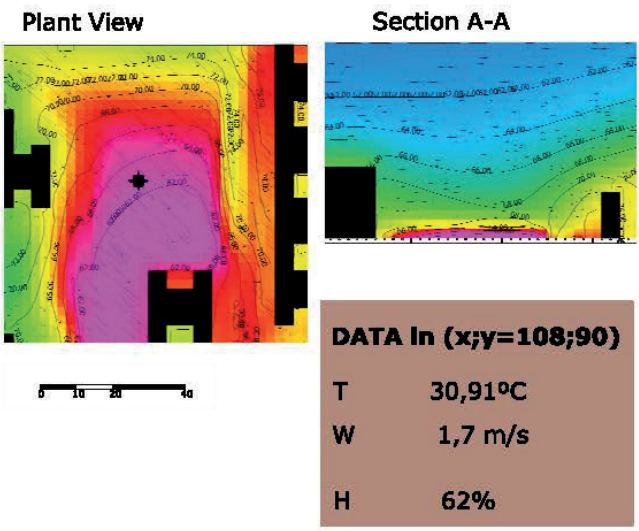

Plant View

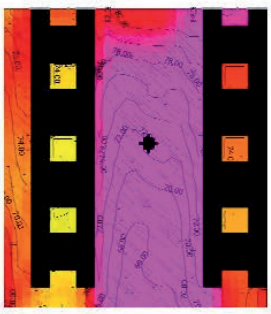

$\overbrace{10}^{2}$
Section A-A

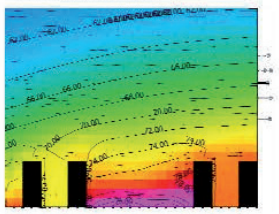

DATA in

$(x+y=192 ; 90)$

$\mathrm{T}$

$31,20^{\circ} \mathrm{C}$

$1,32 \mathrm{~m} / \mathrm{s}$

$\mathrm{H}$

$72 \%$
Parking Area:

Parking area at ground level, soil in asphalt. In the left side there is $\mathbf{1 1}$ storeys building, in the south and east sides there are $\mathbf{5}$ storeys buildings. On the east side the parking is bordered by the tree-lined boulevard.

\section{Detailed Observation of Parking Area}

The parking area shows higher temperature, velocity of winds, mean radiant temperature and lower relative humidity than the rest of area. Take emphasize on that the simulation shows a significant accumulation of heat, but this heat is dissipated within a few meters of altutude. In helght the result shows a temperature reduction in the first 3 meters with a gradlent of $-0.62{ }^{\circ} \mathrm{C} / \mathrm{m}$. The Boulevard with trees shows significant mitigating effect microclimatic conditions. This influence can be clearty seen in the distribution of temperatures and relative humldity In plant view as well as in the vertical section.

Canyon between bulldings In IIne: Building block 5 storeys tall, $\mathrm{H} / \mathrm{W}=0,43$, parking at ground level, soll in asphalt with deciduous trees $20 \mathrm{~m}$ tall in the middle of canyon.

\section{Detailed Observation of Canyon}

In the canyon between buildings the simulation shows high temperature, high wind speeds and low humldity. Unllke the parking, the vertical heat dissipation occurs at higher elevations. In the first 3 meters of helght the temperature with an average temperature gradlent of $-0.2{ }^{\circ} \mathrm{c} / \mathrm{m}$ up to the top of the bulldings roofs. The southwest facade and courtyard Is warmer than the Northeast. 


\section{STEP 5. ENVImet SImulation Result - Day 21th december, time 15:00 h}
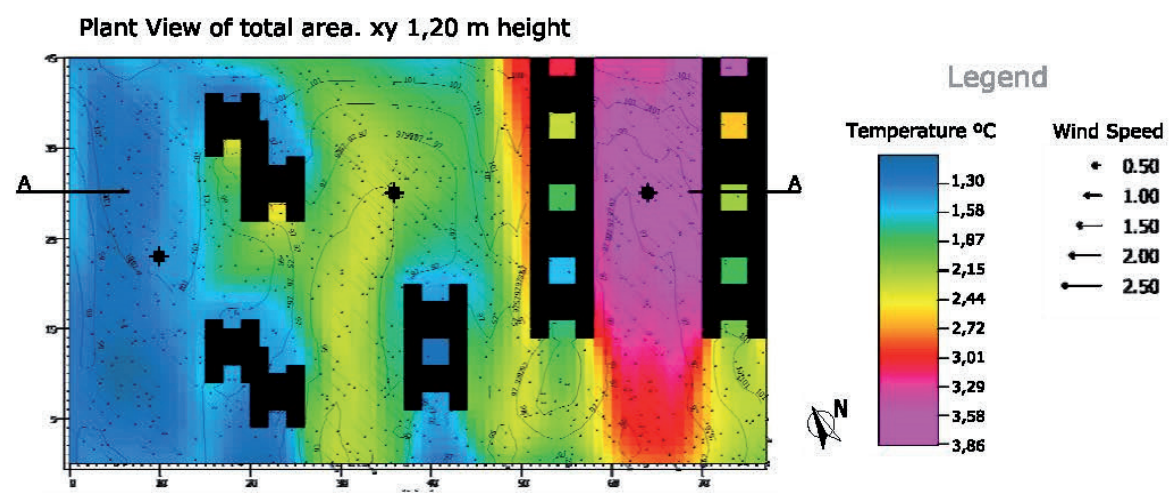

Section A-A view total area
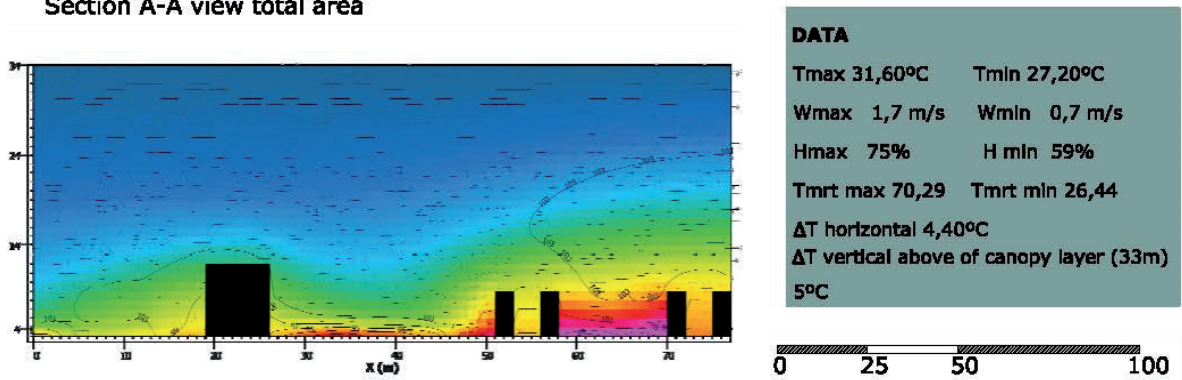

\section{General Observation of Simulation Result}

-In winter conditions, the microdimatic differences in the area are lower than in the summer, the simulation shows a more homogeneous behavior.

-The influence of vegetation on temperature reduction is lower than the simulation carried out in summer condition.

- The vertical section shows that the Influence of urban structure on the temperature ises above $\mathbf{6 0}$ meters, corresponding more than $2 \mathrm{H}$ helght of the tallest bullding. 


\section{Schedule of case study analysis: FONTARRON}

All of data showed have been obtained through simulation process with ENMmet 3.1 and ECOTECT

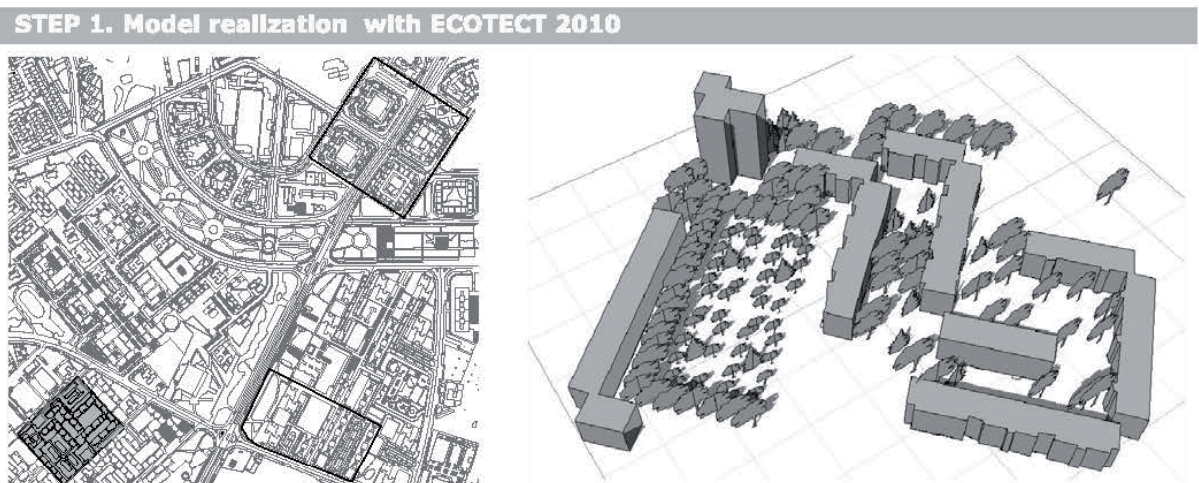

Model 3D vlew with shadow

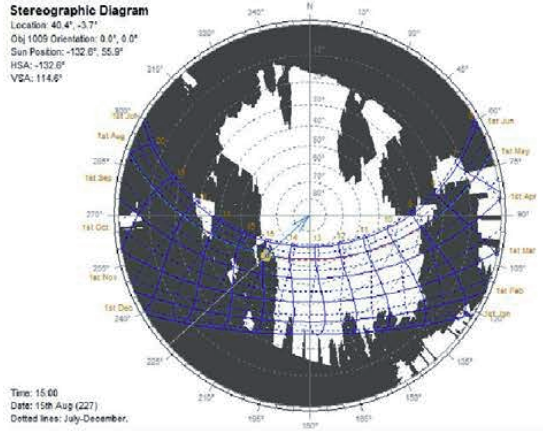

Skye View Factor Analysis

Observation point in the centre of pedestrian square
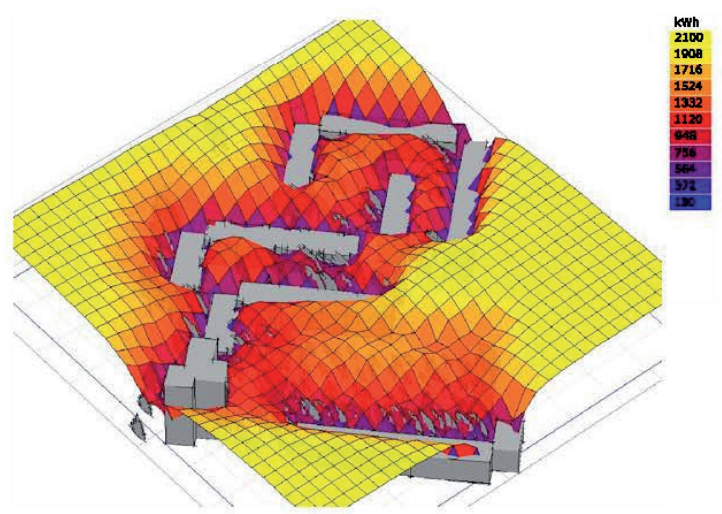

Solar direct radiation analysis.

Ammount and dlstribution of solar direct radlatlon for the 15th august al 15:00 h.

\section{Observation SVF analysis}

The study with ecotec is IImited to analyze

the component of the direct solar radiation in

the summer condition, simulated on the 15th

of August. The Stereographlc dlagram of SVF,

measured In the center of the parking, shows

that the area is exposed to the sun for the

most of the year. Emphasize that in the

middle of the day ( $11 \mathrm{a} . \mathrm{m} .-4$ p.m.) the polnt is not shaded in any month of the year.
Observation solar radiation analysis

Direct solar radiation in the pedestrian are between the buildings is less than that in the surrounding areas, where the presence of tall trees is lower. The trees provide a sunscreen to the facades of buildings and the area of the canyon. The canyon with east-west is the one with the least direct incoming solar radiation during the hours of naximum radiation. 

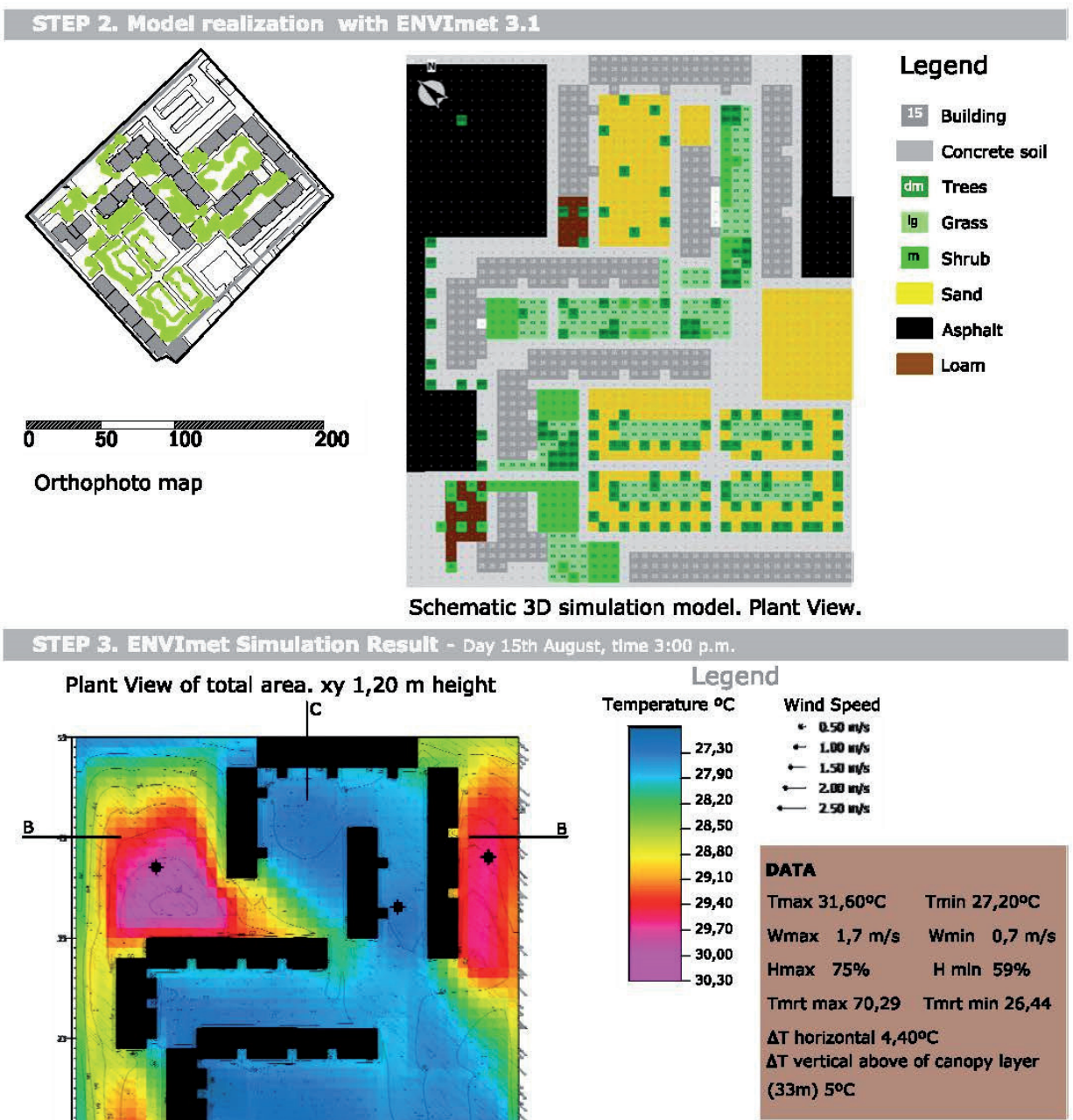

General Observation of Simulation Result

-From the simulation this case study shows a lower average temperature and a more homogeneous distribution than the other two cases. The microclimatic difference on plant and vertical is the lowest and the Influence of the urban structure on microclimate is low.

-The heat accumulation areas are clearly the parking areas that are formed as black bodies without sunscreen.

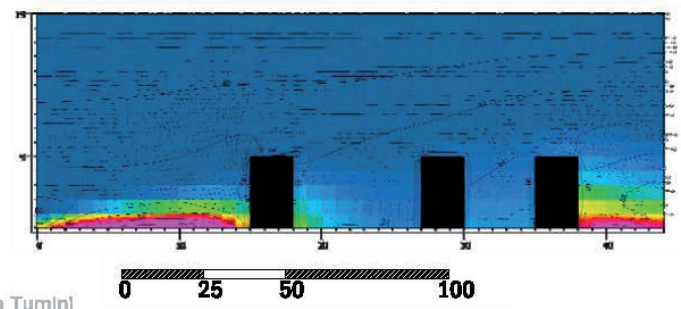

- The canyons, characterized by the presence of green gardens and tall trees, are areas with lower temperature and low wind speed.

- The temperature is quite homogeneous throughout the area, remains constant in the canyons and pedestrian square with trees. Only

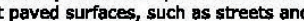
parking, can be distinguished. 
SIEP 4. ENVImet Slmulation Result - Detailed review Day 15th August, time 3:00 p.m.

Plant Vlew

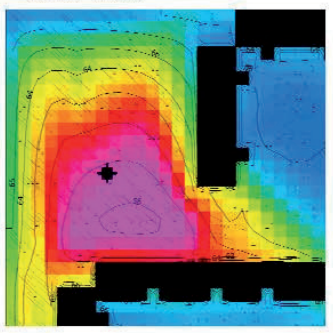

Section B-B

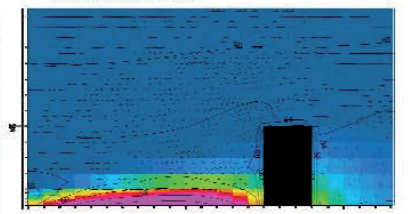

${ }_{10020}^{10}$

\section{Parking Square:}

Parking at ground level, soil in black asphalt without trees or shading. Flve floor bulldings in the south and east side.

DATA in
(x;y=24;120)
T $\quad 30^{\circ} \mathrm{C}$
V $\quad 1,44 \mathrm{~m} / \mathrm{s}$
H
T7\%

\section{Detailed Observation of Parking Area NW}

From the simulation condition In summer, the parking proves that is a clearly point of heat accumulation. Here can be observed that the temperatures are hlgher throughout the study area. The accumulation of heat is produced only In low helght, the disslpation occurs In the first three meters with a gradlent of $-1,05{ }^{\circ} \mathrm{C} / \mathrm{m}$. The wind speed Is high due to absence of barrlers or obstructions, whlle the relatlive humldity Is lowest than In the rest area.

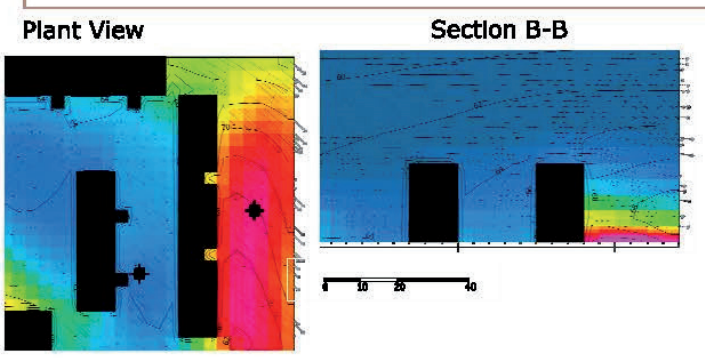

\section{Line Parking area and canyon} Orlentation NE-SW:

Parking at ground level, soll in black asphalt without trees or shading. Five floor building in the west side.

\begin{tabular}{lll} 
DATA in (x,y) & $(123,123)$ & $(96,117)$ \\
\hline & $29,6{ }^{\circ} \mathrm{C}$ & $27,68{ }^{\circ} \mathrm{C}$ \\
W & $1,56 \mathrm{~m} / \mathrm{s}$ & $0,77 \mathrm{~m} / \mathrm{s}$ \\
H & $66 \%$ & $65 \%$
\end{tabular}

\section{Detalled Observation of LIne Parking area and canyon Orlentatlon NE-SW}

The calculation result shows a very Important difference In microclimatic conditlons between the parking area and the canyon. The parking area shows temperature and wind speed high and relative humldity low. On the contrary, the area of the canyon shows temperature and wind speed low. This is mainly due to the presence of vegetation between bulldings. In the vertical development, the parking shows a rapld temperature decrease with a diss/pation gradient about $-0,72{ }^{\circ} \mathrm{C} / \mathrm{m}$. In the canyons the vertical varlation is negliglble, while it is quite Important the increase of the wind speed up the top of bulldings.

Plant View

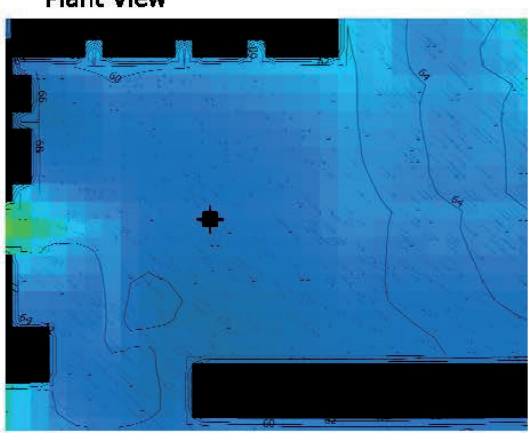

\section{Section C-C}

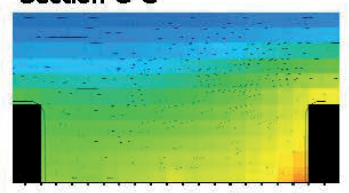

$\longrightarrow$
Garden Square

Square with flowerbeds with grass and small trees, in the edge Horse chestnut trees $15 \mathrm{~m}$ tall are located. Five floor buildings in the border.

DATA In $(\mathrm{X} ; \mathrm{y}=69 ; 39)$

T $\quad 27,50^{\circ} \mathrm{C}$

v $\quad 0,70 \mathrm{~m} / \mathrm{s}$

H $\quad 61 \%$

\section{Detailed Observation of Canyon}

The area of the pedestrlan square garden shows the most comfortable conditlons throughout the area. The presence of trees is manifested in: a) lower temperature 2) low wind speed 3) average value of humidity. From the graphics, the channeling of wind In the gap between the two bulldings on the left side can be seen. That causes an Increasing of wind speed, while it is almost zero at the north façade. 


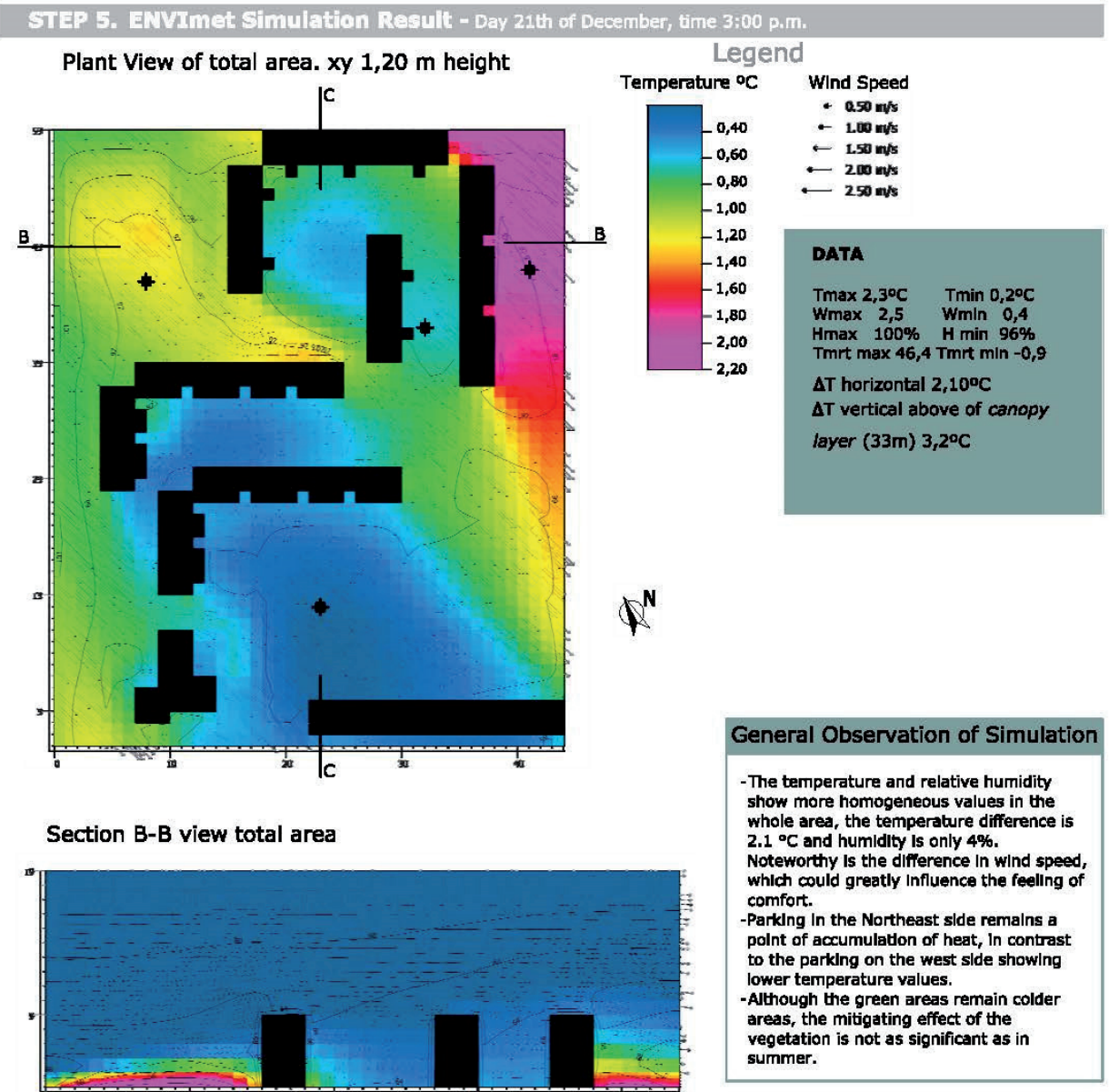

Section C-C view total area

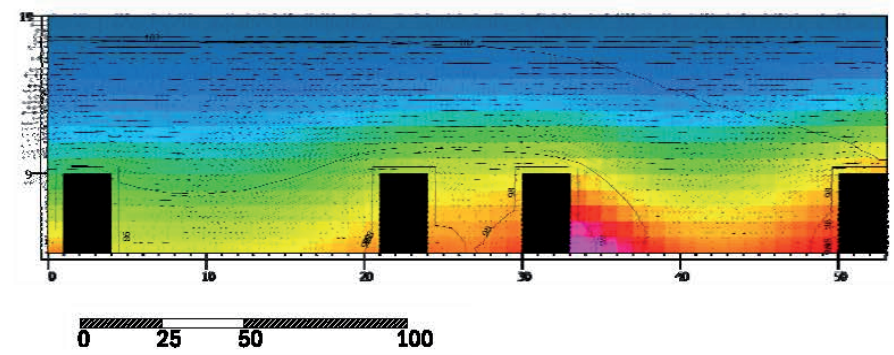




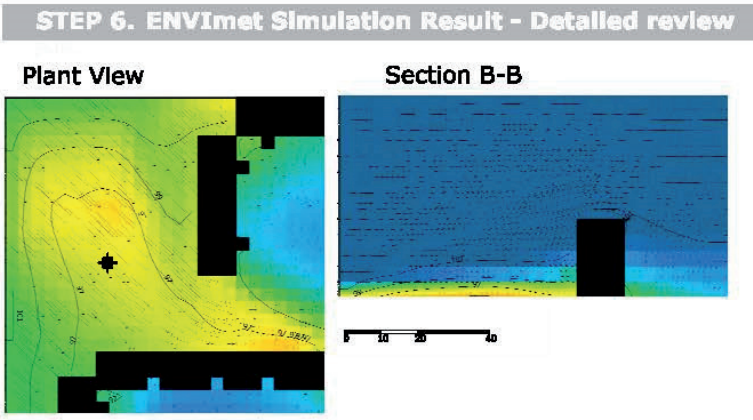

Day 21 Decembre, time 3:00

\section{Parking Square:}

Parking at ground level, soil in black

asphalt without trees or shading.

Flve floor bulldings in the south and

east side.

\begin{tabular}{|c|c|}
\hline DA & $n(x ; y)=2$ \\
\hline $\mathbf{T}$ & $1,19^{\circ} \mathrm{C}$ \\
\hline$w$ & $1,52 \mathrm{~m} / \mathrm{s}$ \\
\hline H & $95 \%$ \\
\hline
\end{tabular}

\section{Detailed Observation of Parking Area NW}

In the parklng area, the temperature values are sllghtly hlgher than In pedestrlan areas. Unllke than the condltion shown in summer, in winter this zone is not the hottest of area. The effect of temperature reduction can be detected especlally in the vertical section that shows the accumulated heat is dissipated in the first 2 meters of altitude.

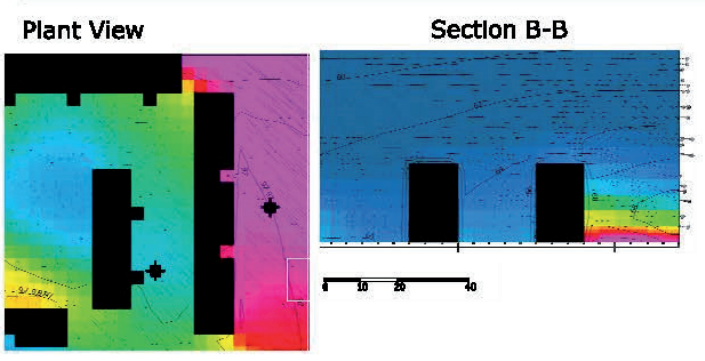

\section{Line Parking area and canyon}

Orlentation NE-SW:

Parking at ground level, soll in black

asphalt without trees or shading. Five floor building in the west side.

DATA in (xFy) $(123,123)$
$\begin{array}{lll}\text { T } & (96,117) \\ W & 2,05{ }^{\circ} \mathrm{C} & \text { T } 0,65{ }^{\circ} \mathrm{C} \\ W & 1,63 \mathrm{~m} / \mathrm{s} & \text { W } 0,75 \mathrm{~m} / \mathrm{s} \\ \text { H } & 97 \% & \text { H } 99 \%\end{array}$

Detailed Observation of Line Parking area and canyon Orientation NE-SW

The parking area is the hottest of case study. The calculation process shows a heat storage, more important in correspondence of West façade. In the canyon area the behavlour is the same described for the summer condictions.

Plant View

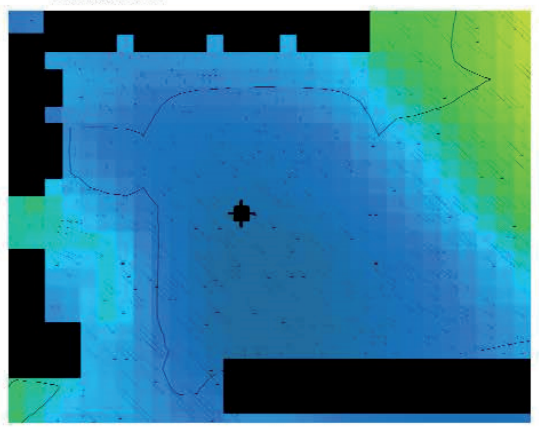

\section{Section C-C}

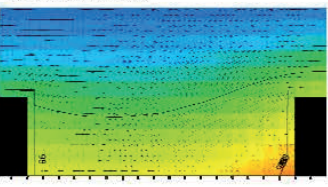

$\underset{10}{20-20}$
Garden Square:

Square with flowerbeds with grass and small trees, in the edge Horse chestnut trees

$15 \mathrm{~m}$ tall are located. Five

floor buildings in the border.

DATA In $(x+y=69 ; 39)$

T $\quad 0,24^{\circ} \mathrm{C}$

$0,75 \mathrm{~m} / \mathrm{s}$

$99 \%$

\section{Detailed Observation of Canyon}

In winter condltions the area of pedestrlan square garden shows the same behavlor of the summer: a)lower temperatures b) low wind speed c) relative humidity in the average value of the area. In winter, the low wind speed reduces the feelling of dlscomfort. 

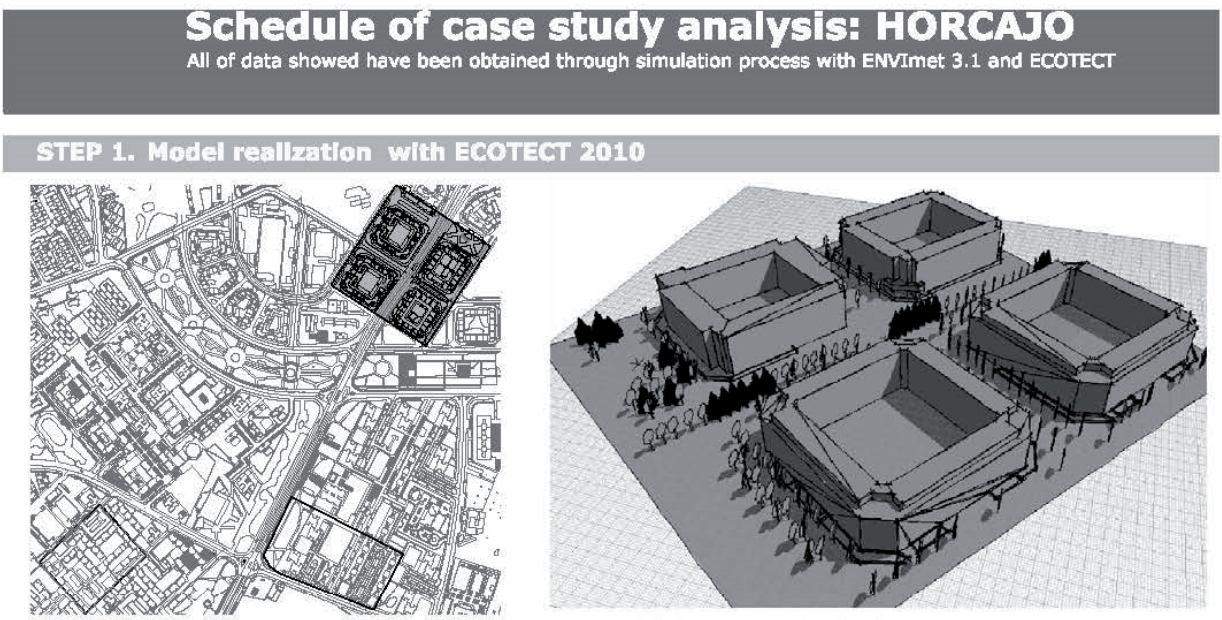

Model 3D vlew with shadow

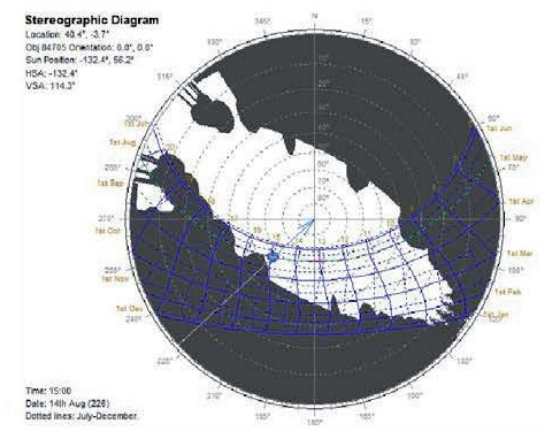

Skye View Factor Analysis

Observation point in the centre of pedestrian square

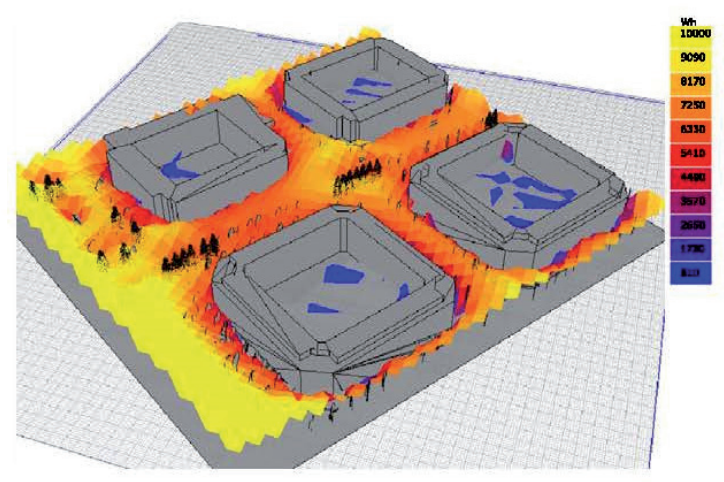

Solar direct radiation analysis.

Ammount and dlstribution of solar direct radlation for the 15th august al 15:00 h.

\section{Observatlon SVF analysis}

The SVF estimation carrled out In the center of the canyon between the two building

blocks, shows that during the hottest months of the year, from June to August, the area is exposed to direct sunllght in the hottest hours of the day, and as consequence, the

accumulation of heat is greater. In the winter months, especlally January and December, the area remains shaded during the most of the day.

\section{Observation solar radiation analysis}

The study shows that in the canyons the direct solar radiation at $3 \mathrm{p} . \mathrm{m}$. in August 15th is lower than in the road center. Thl is due to the effect of shade provided by trees placed along the way. In the canyon, the radlation is lower close to the bullding's façades, whlle on the maln road the effect of shading provided by the central row of trees cannot be appreciated. 


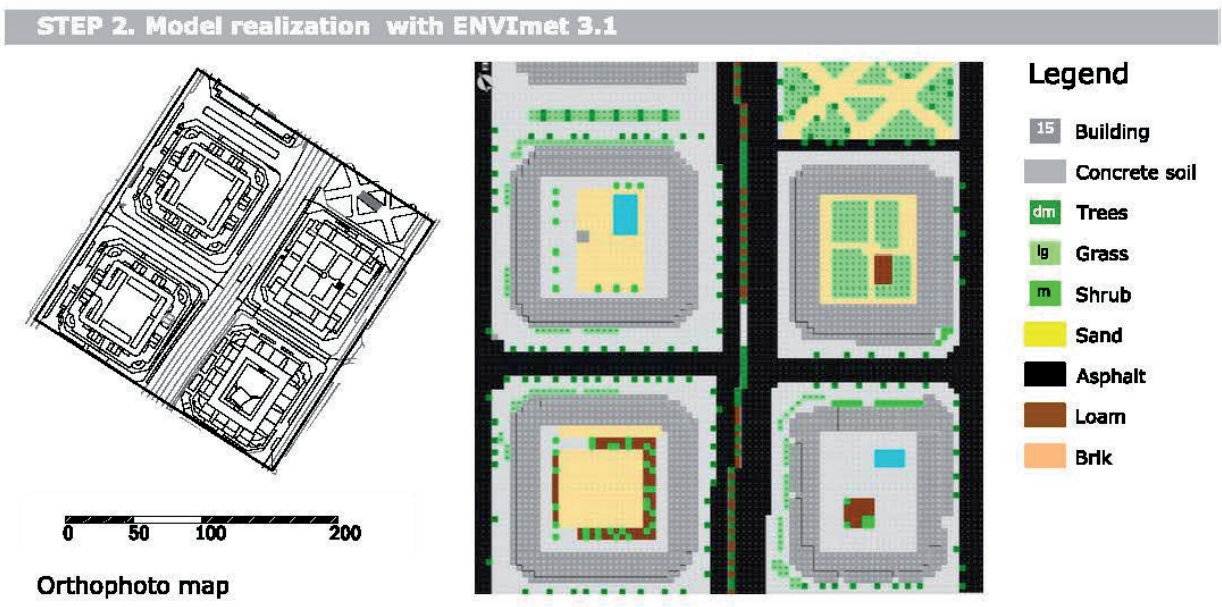

Schematic 3D simulation model. Plant View.

STEP 3. ENVImet Simulation Result - Day 15th August, time 3:00 p.m.

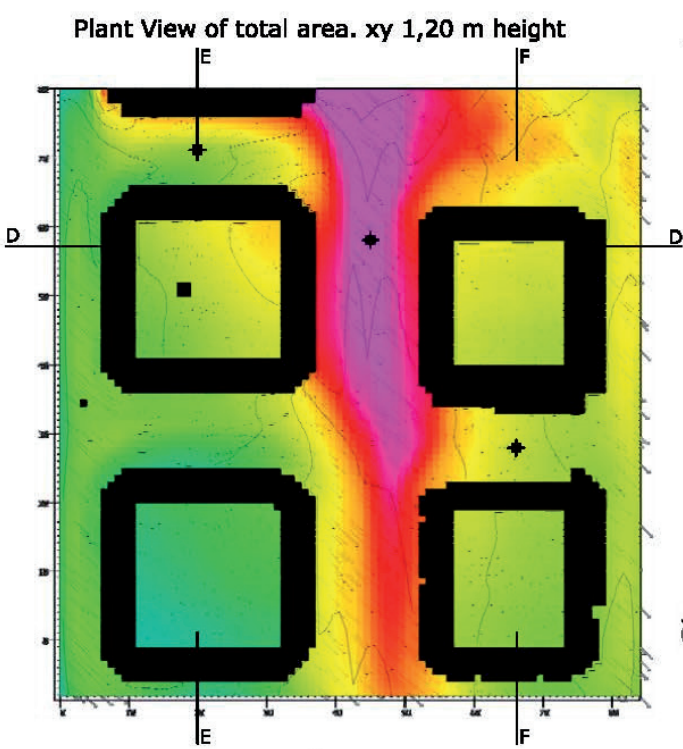

Section D-D view total area

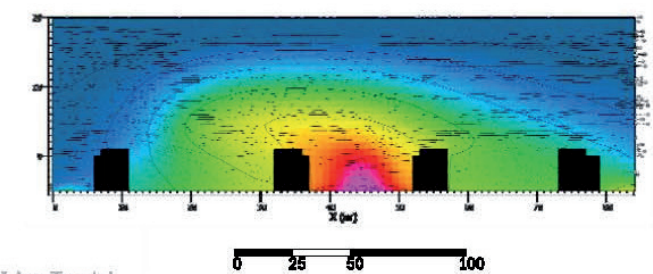

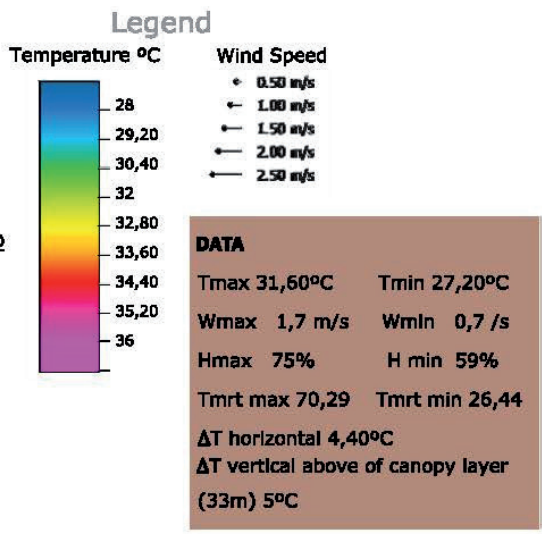

General Observation of Simulation Result

$Q^{N}$-The case result shows considerable variation between different areas in both horlzontal and helght development.

-The urban morphology affect the microcllmate whith strong effect up to an altitude of 75 meters, more of the $4 \mathrm{H}$, where $\mathrm{H}$ is maximum height of buildings.

-The distribution of the relative humidity isolines follows the trend of the temperature: humldity values higher in colder areas.

-Of the three case studles analyzed, Horcajo is the one with higher temperatures and worst conditions of comfort. 
STIP 4. ENVumet Sinulation Result - Detalled review Day 15th August, time 3:00

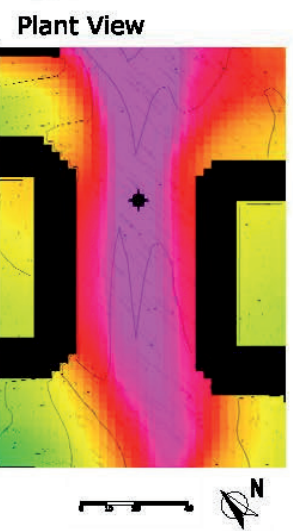

Section D-D

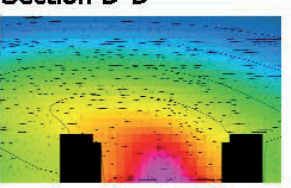

Fuente Carrantona Road canyon - Orfentation NE-SW 430azimut

Fast-flowing road to 4 lanes, ground in black asphalt. On

the sides of the road are placed isolated trees of small

ports and the average height of the buildings is 6 storeys.

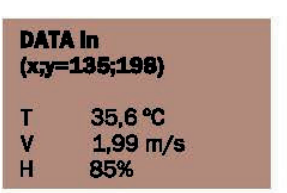

Detalled Observation of Fuente Carrantona Road

The roadway of the street is a llnear heat storage element, were its maximum is in the middle of the road. The heat gets trapped between the bulldings Impeding dissipation.

Desplte the strong wind speed, the heat accumulation at the road level remain constant up to the height of 9 meters. The temperature gradlent from ground up to roofs is of $-0,12{ }^{\circ} \mathrm{C} / \mathrm{m}$

Plant View

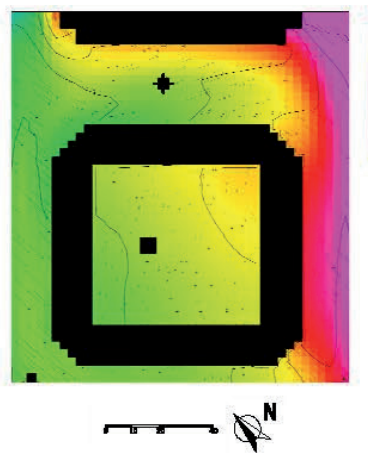

Section E-E
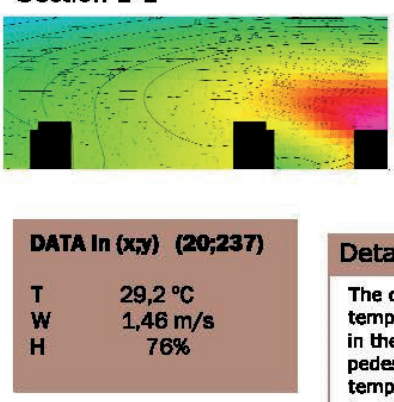

Detailed Observation of Cobeña street canyon

The conditlons simulated by the software Indlcate that the temperature in the canyon and In the courtyard Is lower than in the road. The Cobeña street canyon is coccupied by a pedestrlan area with trees. The presence of trees result in temperature decrease at ground level. The speed of the wind Is qulte strong along the streets and above roofs, and calm In the canyon and courtyeard. In the courtyard, the south facade shows temperature values hotter than the opposite side.

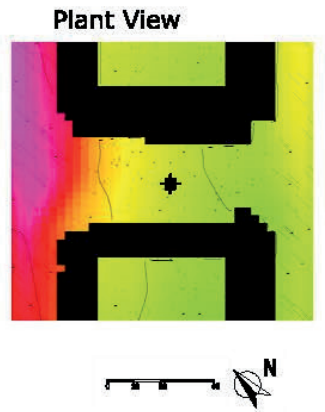

S
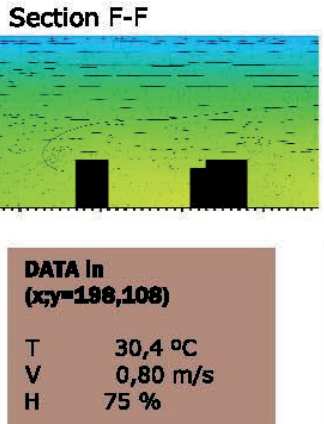

Provenza street canyon - Orlentation NW-\$E 43\%azlmut: Courtyeard bulldings 6 storeys tall and with

$H / W=0,6$. The road in black asphalt and pavements in concrete

Detalled Observation Provenza street canyon

The wind distribution is crucial in the thermal behavior of the canyon. The northwest wind enters In the area, dissipating hea in the blocks on the west slde, It converges Into the central road and colldig whe the wind from the block. Thls causes calm wind and alr stagnaton in the canyon between the bulldings on the east side of the area. That can be clearly seen in the vertical section, where any signifacant microdimate changes cannot be appreciated up to the top of building. 


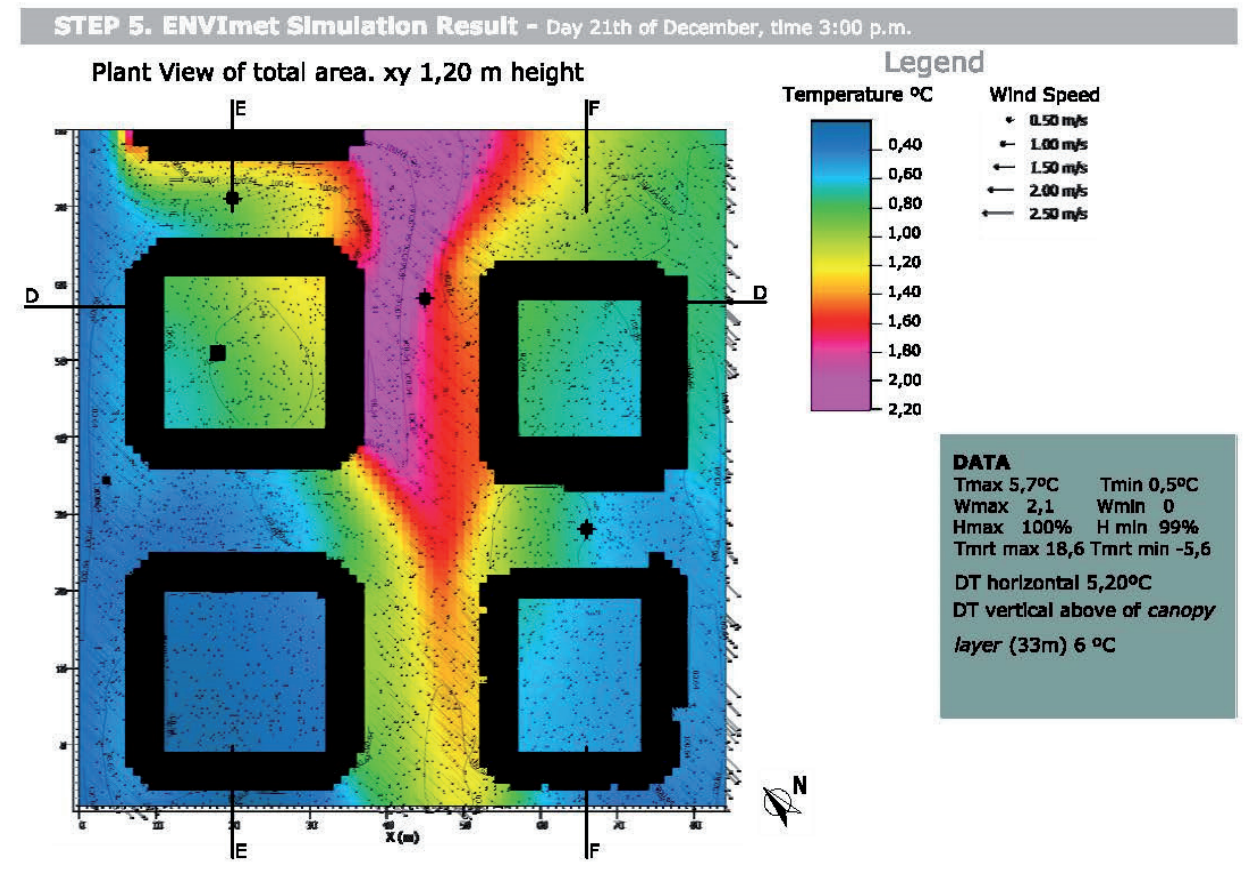

Section D-D view total area

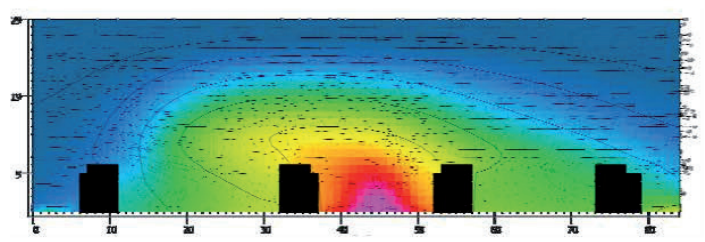

Section E-E view total area

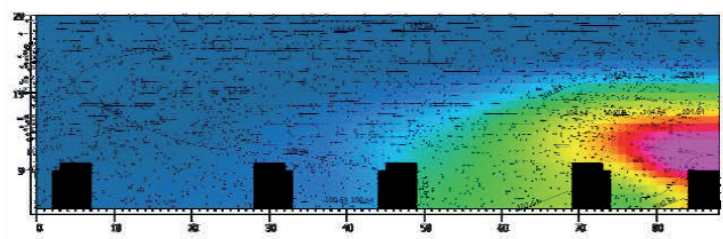

Section E-E view total area

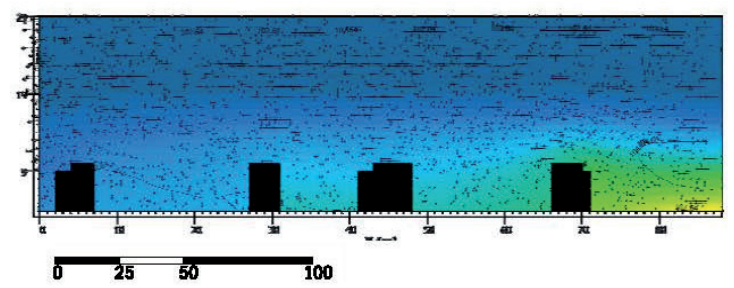

\section{General Observation of Simulation}

- In winter the area shows a behaviour very slmillar to that obtained In summer

conditions. The temperature and relative humldity are more homogeneous and can be highilght less difference between hot and cold areas.

The vertical heat dissipation start above roofs and greater accumulation of heat in correspondence of the south facades of the bulldings is shown. 


\section{SIEP 6. ENVImet Simulation Result - Detalled rovlew Day 21 Decembre, time 3:00}

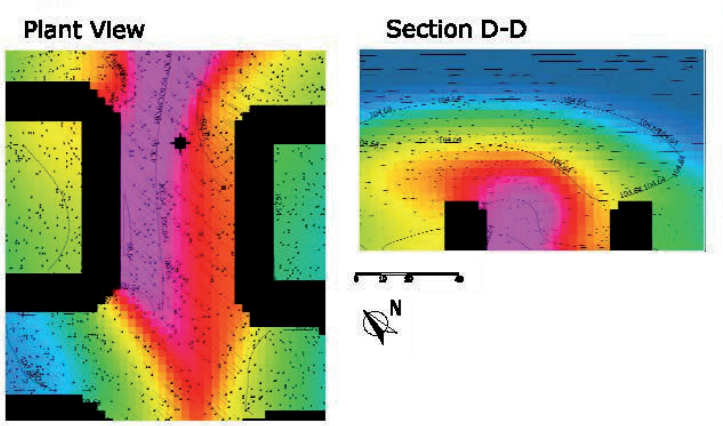

Fuente Carrantona Roed canyon - Orientation NE-sw 430azlmut

Fast-flowing road to 4 lanes, ground in

black asphalt. Along the road small portsare

isolated trees placed and the average

height of the buildings is 6 storeys.

Detailed Observation of Fuente Carrantona Road canyon

Uke that showed in the summer conditlons, the roadway is the heat storage element, but in winter the maximum is

located in correspondance of west façade. This phenomenon can be better explained in the vertical section view, which It shows high temperature in the west façade up to $36 \mathrm{~m}$ of elevation.

Plant View

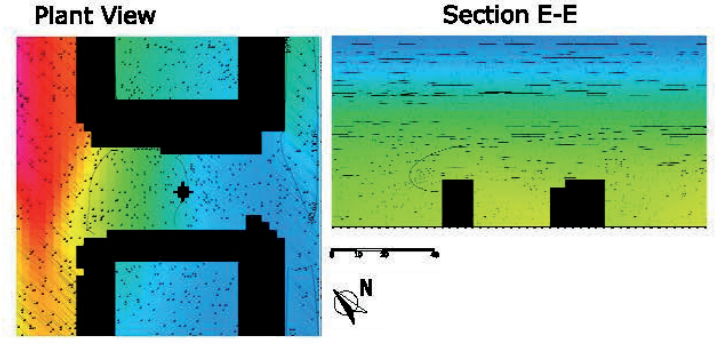

Coberia otreet canyon and block courtyard Orientation NW-SE 43azimut

Courtyeard buildings 6 storeys tall and

with $\mathrm{H} / \mathrm{W}=0,6$. The road in black asphalt

and pavements in concrete.

\section{Detailed Observation of Cobeña street canyon and courtyard blocks}

As well as the simulation In summer conditions, the temperature In the canyon and In the courtyard Is lower than those in the road. The winter, it show a higher temperature at the southwest facade and at above top of roof.

Plant View

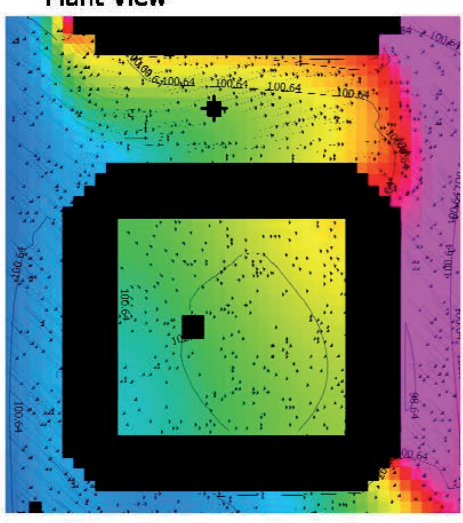

Section F-F

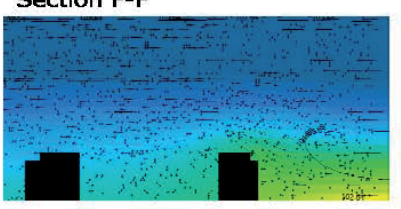

TI: $q^{N}$

DATA In (x;y) $(20,237)$

$\mathrm{T} \quad 1,8^{\circ} \mathrm{C}$

$1,5 \mathrm{~m} / \mathrm{s}$

$100 \%$

DATA in (x;y=135;198)

$3,6^{\circ} \mathrm{C}$

$2,1 \mathrm{~m} / \mathrm{s}$

$100 \%$ 
LOS CUADERNOS DE INVESTIGACIÓN URBANÍSTICA publicados por el Departamento de Urbanística y Ordenación del Territorio desde el año 1993, difunden bimensualmente aquellos trabajos de investigación realizados en el área del Urbanismo, la Ordenación Territorial, el Medio Ambiente, la Planificación Sostenible y el Paisaje, que por sus características, muchas veces de investigación básica, tienen difícil salida en las revistas profesionales. Su objetivo es la difusión de estos trabajos, en el convencimiento de que es necesario potenciar el uso de este idioma entre el mundo científico para conseguir alcanzar ámbitos de difusión a los que, de otra forma, no se podría acceder.

Su formato no es el convencional de una revista de este tipo, con artículos de diferentes autores que, en realidad, abordan aspectos parciales de cada trabajo, muy adecuados para la difusión y el conocimiento rápido de los mismos, pero que no pueden profundizar demasiado debido a su limitada extensión, sino que se trata de amplios informes de la investigación realizada que ocupan la totalidad de cada número. Esto permite, sobre todo a aquellos investigadores que se inician, el tener accesibles los aspectos más relevantes del trabajo y conocer con bastante precisión el proceso de elaboración de los mismos.

La realización material de los Cuadernos de Investigación Urbanística está a cargo del Departamento de Urbanística y Ordenación del Territorio de la Escuela Técnica Superior de Arquitectura de Madrid, garantizándose el respeto de la propiedad intelectual, pues el registro es siempre en su totalidad propiedad del autor. Está permitida su reproducción parcial en las condiciones establecidas por la legislación sobre propiedad intelectual citando autor, previa petición de permiso al mismo.

\section{NORMAS DE PUBLICACIÓN}

Las condiciones para el envío de originales se pueden consultar en la página web:

http://www.aq.upm.es/Departamentos/Urbanismo/publicaciones/ciurpublicar.html

\section{FORMATO DE LAS REFERENCIAS}

Monografías: APELLIDOS (S), Nombre (Año de edición). Título del libro (No de edición). Ciudad de edición: Editorial [Traducción castellano, (Año de edición), Título de la traducción, No de la edición. Ciudad de edición: editorial].

Partes de monografías: APELLIDOS (S), Nombre (Año de edición). "Título de capítulo". En: Responsabilidad de la obra completa, Título de la obra (No de edición). Ciudad de edición: Editorial.

Artículos de publicaciones en serie: APELLIDOS(S), Nombre (Año de publicación). "Título del artículo", Título de la publicación, Localización en el documento fuente: volumen, número, páginas.

Asimismo, se recuerda que el autor tendrá derecho a tres ejemplares gratuitos.

\section{CONSULTA DE NÚMEROS ANTERIORES/ACCESS TO PREVIOUS WORKS}

La colección completa se puede consultar en color y en formato pdf en siguiente página web:

The entire publication is available in pdf format and full colour in the following web page:

http://www.aq.upm.es/Departamentos/Urbanismo/publicaciones/ciurnumeros.html

\section{ÚLTIMOS NÚMEROS PUBLICADOS:}

95 Luz Elena Cornejo Ganga: "Categorías de análisis de un modelo de planificación turística sustentable", 96 páginas, Julio 2014.

94 Mattia Bertin: "Cittá al limite. Per una trattazione urbanística del disastro", 78 páginas, Mayo 2014.

93 Luis Alberto Salinas Arreortúa: "Transformaciones urbanas en el contexto neoliberal", 74 páginas, Marzo 2014.

92 Pedro Fidalgo: "Aportaciones para la definición de elementos visuales determinantes del paisaje", 92 páginas, Enero 2014.

91 Nersa Gómez de Perozo: "Evaluación del microespacio urbano en clima cálido-húmedo", 74 páginas, Noviembre 2013. 
PREINSCRIPCIÓN DEL 15 DE MARZO AL 27 DE JUNIO DE 2014

DIRECTOR DEL MÁSTER: Ester Higueras García

PERIODO DE DOCENCIA: Septiembre 2014 -Junio 2015

MODALIDAD: Presencial y tiempo completo

NUMERO DE PLAZAS: 40 plazas

CREDITOS: 60 ECTS

El Máster se centra en la comprensión, análisis, diagnóstico y solución de los problemas y la identificación de las dinámicas urbanas y territoriales en curso, atendiendo a las dos dimensiones fundamentales del fenómeno urbano actual: por un lado, el proceso de globalización y, por otro lado, las exigencias que impone la sostenibilidad territorial, económica y social. Estos objetivos obligan a insistir en aspectos relacionados con las nuevas actividades económicas, el medio físico y natural, el compromiso con la producción de un espacio social caracterizado por la vida cívica y la relación entre ecología y ciudad, sin olvidar los problemas recurrentes del suelo, la vivienda, el transporte y la calidad de vida. Estos fines se resumen en la construcción de un espacio social y económico eficiente, equilibrado y sostenible. En ese sentido la viabilidad económica de los grandes despliegues urbanos y su metabolismo se confrontan con modelos más maduros, de forma que al estudio de las técnicas habituales de planificación y gestión se añaden otras nuevas orientaciones que tratan de responder a las demandas de complejidad y sostenibilidad en el ámbito urbano.

El programa propuesto consta de un Máster con dos especialidades:

- Especialidad de Planeamiento Urbanístico (Profesional)

- Especialidad de Estudios Urbanos (Investigación Académica)

Se trata de 31 asignaturas agrupadas en tres módulos:

MÓDULO A. Formación en Urbanismo.

MÓDULO B. $\quad$ Formación en Estudios Urbanos e Investigación.

MÓDULO C. Formación en Planeamiento.

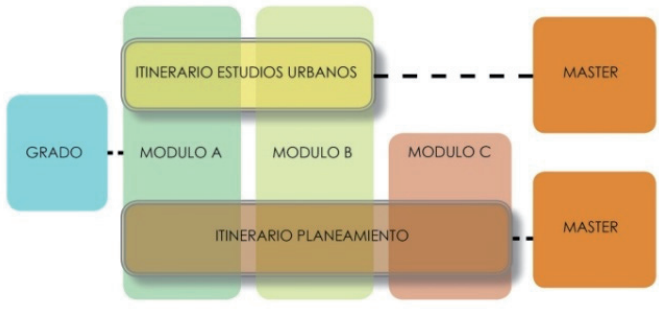

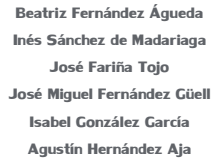

PROFESORADO:

Ester Higueras García
Francisco José Lamiquiz
Julio Pozueta
Fernando Roch Peña
Felipe Colavidas
Luis Moya
José María Ezquiaga

Llanos Masia

Javier Ruiz Sánche

Carlos Verdaguer

Enrique Villa Polo

Carmen Andrés Mateo

Álvaro Sevilla

ENTIDADES COLABORADORAS: Q Cilur] =urban

CONTACTO: masterplaneamiento.arquitectura@upm.es www.aq.upm.es/Departamentos/Urbanismo/masters/index.html 
Otros medios divulgativos del Departamento de Urbanística y Ordenación del Territorio:

\section{urbain}

ReVISTA del DepartamENTO de URBANÍSTICA y ORDENACIÓN del TERRITORIO ESCUELA TÉCNICA SUPERIOR DE ARQUITECTURA

\section{PRESENTACión SEGUNDA ÉPOCA}

DESDE el año 1997, URBAN ha sido vehículo de expresión de la reflexión urbanística más innovadora en España y lugar de encuentro entre profesionales y académicos de todo el mundo. Durante su primera época la revista ha combinado el interés por los resultados de la investigación con la atención a la práctica profesional, especialmente en el ámbito español y la región madrileña. Sin abandonar dicha vocación de saber aplicado y localizado, la segunda época se centra en el progreso de las políticas urbanas y territoriales y la investigación científica a nivel internacional. Ayer y hoy, nuestro objetivo es contribuir al desarrollo de las técnicas y modelos de ciudad y territorio, desde una perspectiva crítica y conjugando las ventajas de nuestra posición en la encrucijada entre el Norte y el Sur globales, entre Europa, el Mediterráneo y Latinoamérica.

Apoyándose en cuatro vectores de interés -carácter generalista y transversal, espíritu crítico, visión regional de los procesos globales y recuperación de la memoria de la disciplina- la nueva URBAN se propone servir de espacio para un debate en el que la planificación se juegue sus condiciones de posibilidad. Frente a la deriva disciplinar de las últimas décadas, frente al desplazamiento paulatino del lugar social de la planificación urbana y territorial en los modos de gobierno, nos parece urgente replantear el papel que ésta merece en las economías políticas de la producción de espacio.

\section{CONVOCATORIA PARA LA RECEPCIÓN DE ARTÍCULOS: nº6- Teoría urbana. Estados del arte}

Sin una teoría urbana consistente nunca habrá buen urbanismo. Este problemático aforismo podría servir para abrir el debate que la revista Urban se propone albergar en un próximo número especial. La teoría urbana (teoría de la ciudad, teoría del proceso urbanizador) ha presentado una relación histórica compleja con la práctica de la planificación y las políticas de la ciudad y el territorio: anticipación de mundos más o menos felices, re-conocimiento pericial de fenómenos urbanos ya materializados, interpretación crítica que re-imagina el pasado y el presente de la ciudad y el territorio, abriéndolos a un nuevo horizonte... El trabajo teórico es, qué duda cabe, un indicador efectivo de la salud y orientación de la disciplina urbanística pero ¿es también un arma cargada de futuro? ¿Cabe aún idear teorías capaces de cambiar los hechos de un mundo urbano que se presenta cada vez más complejo, abigarrado y ajeno a cualquier indicio de racionalidad? ¿Debe la teoría conformarse, por el contrario, con adoptar una actitud de 'testigo modesto', buscar producciones de sentido en los intersticios de los discursos urbanos dominantes? ¿Qué perspectivas teóricas debemos perseguir, con qué herramientas conceptuales y en qué marcos intelectuales? ¿Cómo debe la teoría pensar su articulación con la práctica? ¿Qué tipo de teoría demanda nuestro mundo urbano en un contexto de crisis global? ¿En qué medida los ensayos por comprender la crisis pueden contribuir a ensanchar el campo teórico del fenómeno urbano?

Este número especial de la revista Urban pretende albergar aportaciones internacionales que exploren sistemática y críticamente los estados del arte en los distintos campos de la teoría urbana y los conecten a las tendencias más amplias de la teoría social contemporánea - de la planificación a la geografía, de la sociología a la historia y más allá, en el horizonte general del conocimiento técnico, las ciencias sociales y las humanidades. Serán especialmente bienvenidas las contribuciones que analicen corrientes actuales de reflexión sobre las intersecciones de ciudad, economía, sociedad, política, cultura, tecnología, naturaleza, medio ambiente, diseño, instituciones... Asimismo se espera que los autores consideren y problematicen la articulación entre teoría y práctica urbanística, recordando que 'la experiencia sin teoría es ciega, pero también que la teoría sin experiencia es un mero juego intelectual'. En definitiva ¿cómo puede contribuir la teoría urbana a cambiar no sólo el conocimiento y discurso sobre la ciudad, sino también los propios procesos que la sostienen y transforman? ¿Enfrenta el urbanismo un horizonte de 'miseria de la teoría' o, por el contrario, cabe imaginar un futuro floreciente y un lugar propio para la teoría urbana en el campo más amplio de la teoría social? 
Urban mantiene abierta una convocatoria permanente para la remisión de artículos de temática relacionada con los objetivos de la revista: Para más información:

http://www2.aq.upm.es/Departamentos/Urbanismo/institucional/publicaciones/urban/ns/instrucciones-para-autores/

Por último, se recuerda que, aunque La revista URBAN organiza sus números de manera monográfica mediante convocatorias temáticas, simultáneamente, mantiene siempre abierta de forma contínua una convocatoria para artículos de temática libre.

\section{DATOS DE CONTACTO}

Envío de manuscritos y originales a la atención de Álvaro Sevilla Buitrago: urban.arquitectura@upm.es Página web: http://www.aq.upm.es/Departamentos/Urbanismo/public/urban/info.html

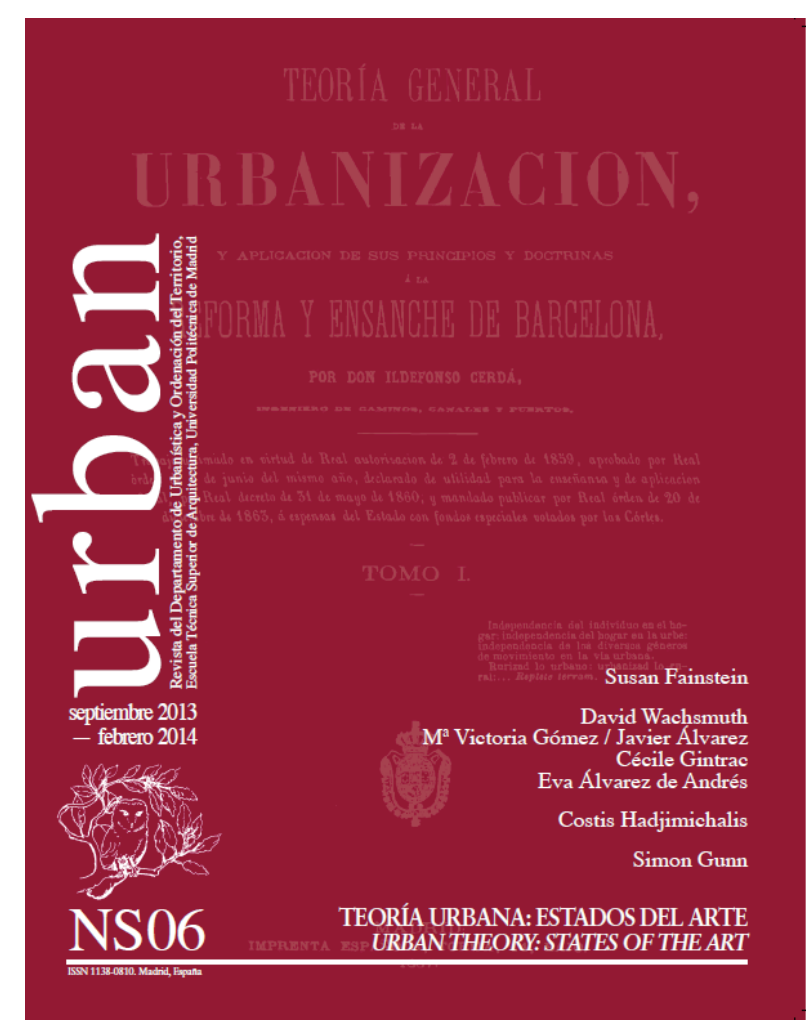

Consulta y pedido de ejemplares: ciur.urbanismo.arquitectura@upm.es

Web del Departamento de Urbanística y ordenación del Territorio:

http://www.aq.upm.es/Departamentos/Urbanismo

Donde figuran todas las actividades docentes, divulgativas y de investigación que se realizan en el Departamento con una actualización permanente de sus contenidos. 


\section{urban-e}

Nace urban-e como hija de la revista académica urban y como colaboradora en la tarea de difundir el debate urbanístico con un enfoque que trata de establecer puentes entre el ámbito teórico y la intervención en la realidad, mediante el análisis de actuaciones ya realizadas o planes y proyectos.

La revista se centra en el territorio, el urbanismo, la sostenibilidad, el paisaje y el diseño urbano como campos de trabajo, abordando las distintas escalas en la construcción, la conservación o la puesta en valor de un medio siempre cambiante en el que el hombre debe vivir de la mejor manera posible, como ya decía Aristóteles. La revista apuesta por las nuevas tecnologías ya que su difusión será exclusivamente digital, y recogerá buenas prácticas en estas materias, abriendo un campo necesario a los profesionales del urbanismo para la difusión de sus trabajos, como contraposición a los de arquitectura, ésta convertida en estrella mediática tiene mayor eco en los medios y llega a la sociedad de manera cotidiana, ignorando el hecho de que la arquitectura precisa valorar el soporte e integrarse en el paisaje natural o urbano para expresarse correctamente.

Se pretende que sea una revista abierta en la que tengan cabida todo tipo de propuestas desde todas las disciplinas que intervienen en la construcción del territorio y de la ciudad. Se publicarán dos números monográficos al año, complementados con una sección de miscelánea, en la que tendrán cabida aquellos artículos que sobre cualquier tema lleguen a la redacción y sean seleccionados, así como trabajos de alumnos, tanto como reconocimiento a su esfuerzo como para propiciar su análisis y comparación para comprobar, desde experiencias de enseñanza distintas la bondad de los resultados.

NúMERO EN CURSO: n² - Nuevas extensiones urbanas: el Ecobarrio como modelo (Otoño 2011)

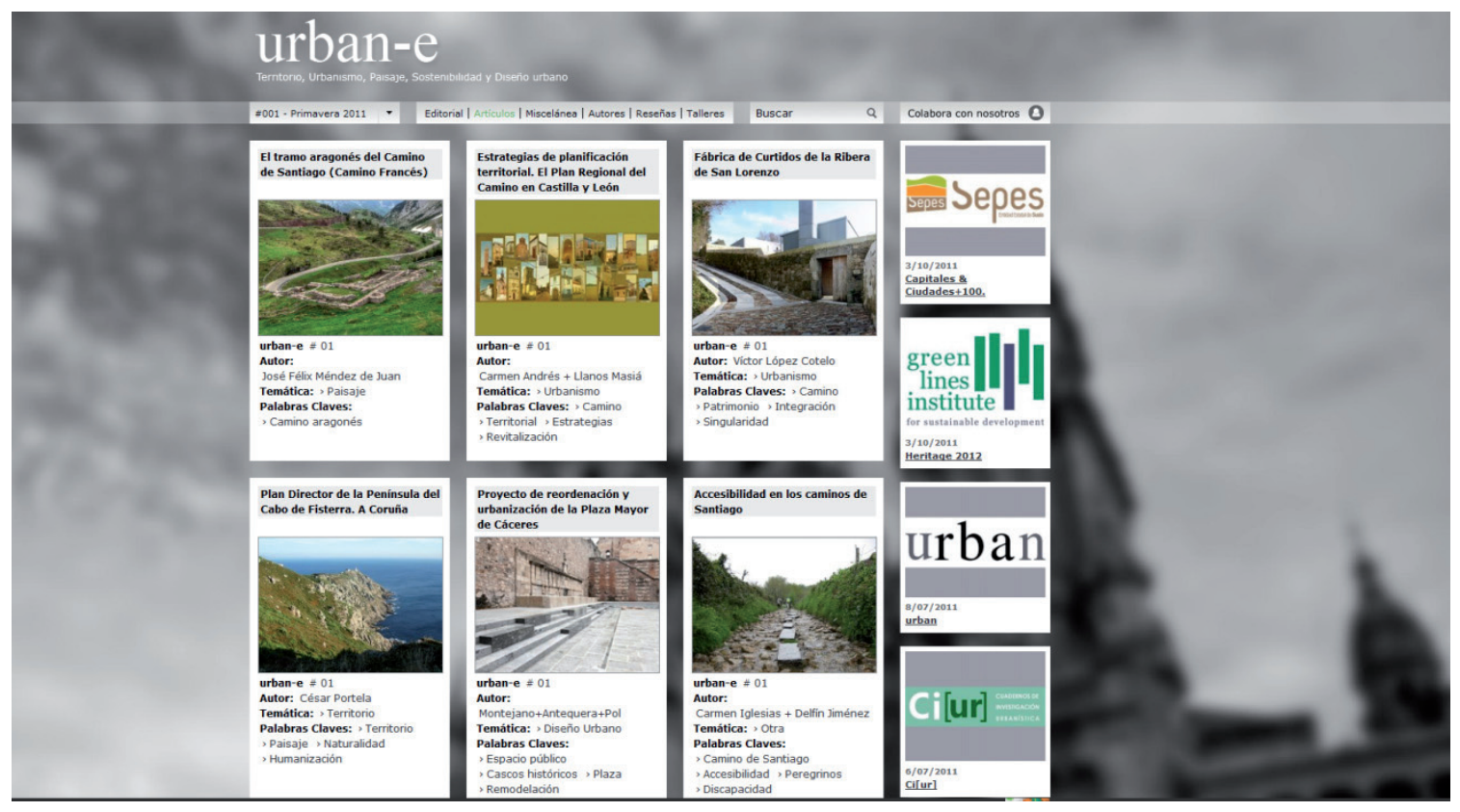

